\title{
Strategic Construction of Sulfur-Bridged BODIPY Dimers and Oligomers as Heavy- Atom-Free Photosensitizers
}

Qingbao Gong, ${ }^{\mathrm{a}}$ Qinghua Wu, ${ }^{\mathrm{a}, \mathrm{b}}$ Xing Guo, ${ }^{\mathrm{a}}$ Wanwan $\mathrm{Li},{ }^{\mathrm{a}}$ Long Wang, ${ }^{\mathrm{a}}$ Erhong Hao ${ }^{\mathrm{a}, *}$ and Lijuan $\mathrm{Jiao}^{\mathrm{a}, *}$

${ }^{a}$ Key Laboratory of Functional Molecular Solids, Ministry of Education; School of Chemistry and Materials Science, Anhui Normal University, Wuhu, 241002, China.

${ }^{b}$ School of Pharmaceutical Sciences, Anhui University of Chinese Medicine, Hefei, 230012, China.

*To whom correspondence should be addressed.

E-mail: haoehong@ahnu.edu.cn, jiao421@ahnu.edu.cn

\section{Contents:}

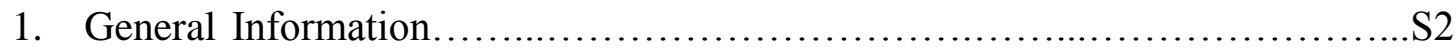

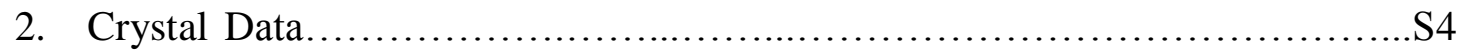

3. Table S3. Optimization of the reaction conditions............................ 6

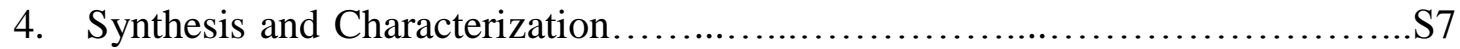

5. Photophysical Data.................................................... 12

6. Reactive Oxygen Species (ROS) Formation.............................S22

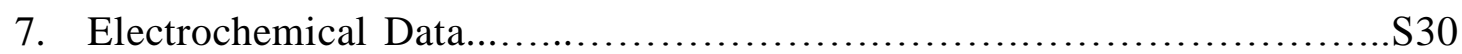

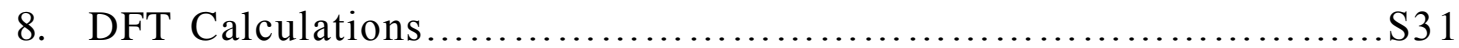

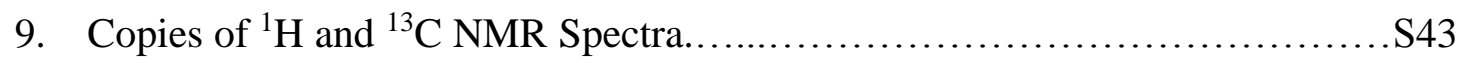

10. High Resolution Mass Spectroscopes for All New Compounds................S51 


\section{General Information}

Reagents and solvents were used as received from commercial suppliers unless noted otherwise. All reactions were performed in oven-dried or flame-dried glassware unless otherwise stated, and were monitored by TLC using $0.25 \mathrm{~mm}$ silica gel plates with UV indicator (60F-254). ${ }^{1} \mathrm{H}$ NMR and ${ }^{13} \mathrm{C}$ NMR spectra were recorded at $500 \mathrm{MHz}$ NMR spectrometer in $\mathrm{CDCl}_{3}$ at room temperature. Chemical shifts $(\delta)$ are given in ppm relative to $\mathrm{CDCl}_{3}\left(7.26 \mathrm{ppm}\right.$ for ${ }^{1} \mathrm{H}$ and $77 \mathrm{ppm}$ for $\left.{ }^{13} \mathrm{C}\right)$ to internal TMS $(\delta=0 \mathrm{ppm})$ as internal standard. High-resolution mass spectra (HRMS) were obtained using ESITOF or MAIDI-TOF in positive mode. The EPR spectra were obtained using a Bruker EMX plus6/1 variable-temperature X-band apparatus.

UV-visible absorption spectra and Fluorescence emission spectra were recorded on a commercial spectrophotometer (Shimadzu UV-2450 and Edinburgh FS5 spectrometers, 190-900 nm scan range). Relative fluorescence quantum efficiencies of these BODIPYs were obtained by comparing the areas under the corrected emission spectrum of the test sample in various solvents with Cresyl violet perchlorate $(\Phi=0.54$ in methanol $)^{1}$ or 1,7-diphenyl-3,5-di(4-methoxyphenyl)-azadipyrromethene $(\Phi=0.36$ in chloroform $)^{2}$. Non-degassed, spectroscopic grade solvents and a $10 \mathrm{~mm}$ quartz cuvette were used. Dilute solutions $(0.01<\mathrm{A}<0.05)$ were used to minimize the reabsorption effects. Quantum yields were determined using the following equation:

$$
\Phi_{x}=\Phi_{r} \times \frac{F_{x}}{F_{r}} \times \frac{1-10^{-A_{r}\left(\lambda_{\mathrm{ex}}\right)}}{1-10^{-A_{x}\left(\lambda_{\mathrm{ex}}\right)}} \times \frac{n_{x}^{2}}{n_{r}^{2}}
$$

Where the subscripts $x$ and $r$ refer respectively to sample $x$ and reference (standard) fluorophore $r$ with known quantum yield $\Phi_{r}$ in a specific solvent; $F$ stands for the spectrally corrected, integrated fluorescence spectra; $A\left(\lambda_{\text {ex }}\right)$ denotes the absorbance at the used excitation wavelength $\lambda_{\mathrm{ex}} ; n$ represents the refractive index of the solvent (in principle at the average emission wavelength).

Crystal of B2-3Cl suitable for X-ray analysis was obtained by slow evaporation of the dichloromethane solution. The vial containing this solution was placed, loosely capped, to promote the crystallization. A suitable crystal was chosen and mounted on a 
glass fiber using grease. The suitable crystals were selected and mounted on a suitable support. Data were collected using a Bruker APEX-II ${ }^{3}$ CCD diffractometer operating at $T=293(2) \mathrm{K}$. The determination of unit cell parameters and data collections were performed with Mo K $\alpha$ radiation $(\lambda)$ at $0.71073 \AA$. The total number of runs and images was based on the strategy calculation from the program APEX2 (Bruker). ${ }^{4}$ The structure was solved by the structure solution program Olex2 (Dolomanov et al., 2009) ${ }^{5}$ and the model was refined with version $2014 / 7$ of ShelXL (Sheldrick, 2015) ${ }^{6}$ using full matrix least squares on $\mathbf{F}^{\mathbf{2}}$ minimisation. CCDC-2098083 (B2-3Cl) contains the supplementary crystallographic data for this paper. These data can be obtained free of charge from The Cambridge Crystallographic Data Centre via www.ccdc.cam.ac.uk/data_request/cif.

Electrochemical measurements. Cyclic voltammograms of $1 \mathrm{mM}$ dyes B1-B6 were measured in dichloromethane solution, containing $0.1 \mathrm{M} \mathrm{TBAPF}_{6}$ as the supporting electrolyte, glassy carbon electrode as a working electrode, Pt wire as a counter electrode, and saturated calomel electrode (SCE) as reference electrode at $100 \mathrm{mV} \mathrm{s}^{-1}$ of scanning rate at room temperature. 


\section{Crystal Data}

Table S1. Selected geometrical parameters of compounds B2-3Cl obtained from crystallography.

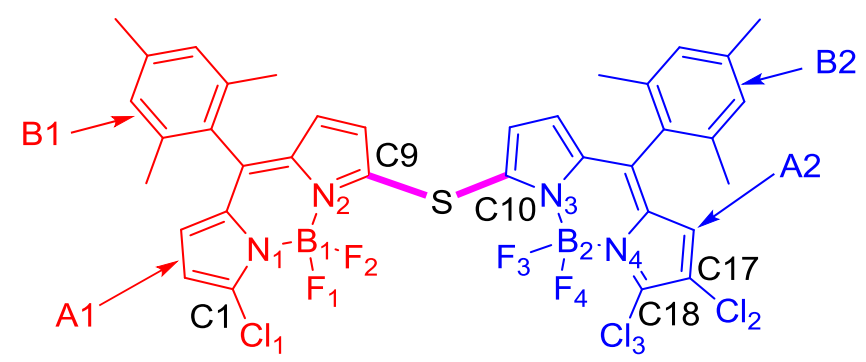

\begin{tabular}{|c|c|}
\hline & B2-3Cl \\
\hline the B-N bond distances $(\AA)$ & $1.561(6)$ \\
& $1.562(6)$ \\
& $1.569(6)$ \\
& $1.571(6)$ \\
\hline the B-F bond distances $(\AA)$ & $1.369(6)$ \\
& $1.377(6)$ \\
& $1.375(6)$ \\
& $1.373(6)$ \\
\hline the C9-S bond distances $(\AA)$ & $1.739(6)$ \\
\hline the C10-S bond distances $(\AA)$ & $1.751(6)$ \\
\hline the C1-Cl1 bond distances $(\AA)$ & $1.700(6)$ \\
\hline the C17-Cl2 bond distances $(\AA)$ & $1.694(6)$ \\
\hline the C18-Cl3 bond distances $(\AA)$ & $1.691(6)$ \\
\hline dihedral angles between meso-aryl B1 and dipyrrin & $74.57(14)$ \\
core A1 (deg) & $76.90(14)$ \\
\hline dihedral angles between $m e s o$-aryl B2 and dipyrrin & \\
\hline core A2 (deg) & $48.82(1)$ \\
\hline dihedral angles between dipyrrin core A1 and & \\
\hline dipyrrin core A2 (deg) & \\
\hline
\end{tabular}


Table S2. Crystal data and structure refinement for B2-3Cl.

Empirical formula

Formula weight

Temperature/K

Crystal system

Space group

$\mathrm{a} / \AA$

$\mathrm{b} / \AA$

$\mathrm{c} / \AA$

$\alpha /{ }^{\circ}$

$\beta /{ }^{\circ}$

$\gamma /{ }^{\circ}$

Volume $/ \AA^{3}$

$\mathrm{Z}$

$\rho_{\text {calc }} / \mathrm{cm}^{3}$

$\mu / \mathrm{mm}^{-1}$

$\mathrm{F}(000)$

Crystal size $/ \mathrm{mm}^{3}$

Radiation
$\mathrm{C}_{36} \mathrm{H}_{29} \mathrm{~B}_{2} \mathrm{Cl}_{3} \mathrm{~F}_{4} \mathrm{~N}_{4} \mathrm{~S}$

753.66

293.15

monoclinic

$\mathrm{P} 2{ }_{1} / \mathrm{c}$

$11.658(7)$

24.861(15)

$12.765(8)$

90

93.629(9)

90

3693(4)

4

1.356

0.357

1544.0

$0.22 \times 0.21 \times 0.18$

$\operatorname{MoK} \alpha(\lambda=0.71073)$

$2 \Theta$ range for data collection/ $/{ }^{\circ} 3.276$ to 50

Index ranges

Reflections collected

Independent reflections

Data/restraints/parameters

Goodness-of-fit on $\mathrm{F}^{2}$

Final $R$ indexes $[\mathrm{I}>=2 \sigma(\mathrm{I})] \quad \mathrm{R}_{1}=0.0699, \mathrm{wR}_{2}=0.1660$

Final $R$ indexes [all data] $\quad R_{1}=0.1324, w_{2}=0.1993$

Largest diff. peak/hole / e $\AA^{-3} 1.44 /-0.45$
$-13 \leq \mathrm{h} \leq 13,-29 \leq \mathrm{k} \leq 29,-15 \leq 1 \leq 15$

36280

$6468\left[\mathrm{R}_{\text {int }}=0.1471, \mathrm{R}_{\text {sigma }}=0.0984\right]$

$6468 / 0 / 457$

0.938 


\section{Table S3. Optimization of the Reaction Conditions. ${ }^{\text {a }}$}
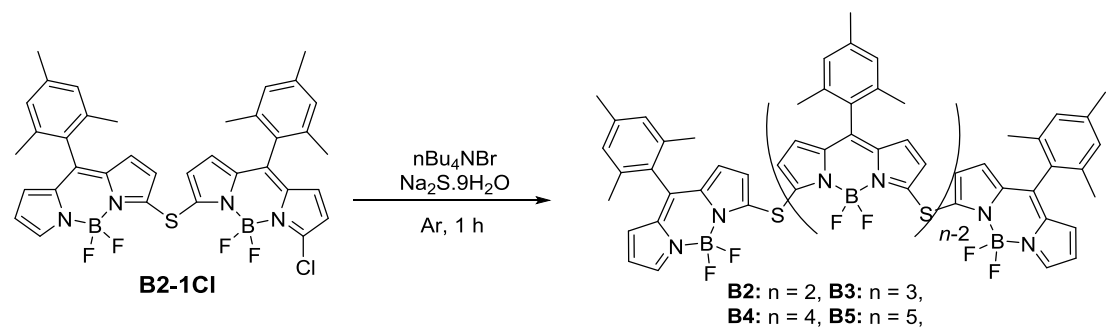

\begin{tabular}{cccccccc}
\hline & & & \multicolumn{5}{c}{ yield $(\%)^{\mathrm{c}}$} \\
\hline 1 & solvent & equiv. ${ }^{\mathrm{b}}$ & temp. $\left({ }^{\circ} \mathrm{C}\right)$ & $\mathbf{B 2}$ & $\mathbf{B 3}$ & $\mathbf{B 4}$ & $\mathbf{B 5}$ \\
\hline 2 & toluene & 0.35 & 80 & 26 & 15 & 7 & 2 \\
3 & toluene & 0.55 & 80 & 11 & 29 & 13 & 6 \\
4 & toluene & 0.75 & 80 & trace & 8 & 5 & trace \\
5 & toluene & 0.55 & 60 & 10 & 25 & 11 & 3 \\
6 & toluene & 0.55 & 100 & 15 & 22 & 8 & 2 \\
7 & CH ${ }_{3} \mathrm{CN}$ & 0.55 & 80 & 4 & 35 & 17 & 7 \\
8 & DMSO & 0.55 & 80 & 5 & 32 & 20 & 8 \\
9 & DMF & 0.55 & 80 & 5 & $\mathbf{3 8}$ & $\mathbf{2 1}$ & $\mathbf{9}$ \\
10 & THF & 0.55 & 80 & 13 & 27 & 12 & 6 \\
11 & $1,2-\mathrm{DCE}$ & 0.55 & 80 & 10 & 25 & 11 & 6 \\
\hline
\end{tabular}

${ }^{a}$ Reaction conditions: B2-1Cl $(0.1 \mathrm{mmol}), \mathrm{nBu} 4 \mathrm{NBr}(0.02 \mathrm{mmol}), 4.0 \mathrm{~mL}$ of solvent, Ar. ${ }^{b}$ the amount of $\mathrm{Na}_{2} \mathrm{~S} .9 \mathrm{H}_{2} \mathrm{O} .{ }^{c}$ Isolated yields based on $\mathbf{B 2 - 1 C l}$. 


\section{Synthesis and Characterization}

BODIPYs B1 and B1-Cl was synthesized according to the literature. ${ }^{7}$

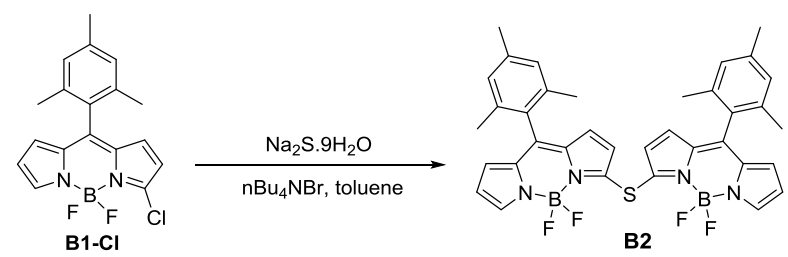

Synthesis of BODIPY B2: To a solution of B1-Cl $(69 \mathrm{mg}, 0.2 \mathrm{mmol})$ in toluene (2 mL) were added water $(0.02 \mathrm{~mL}), \mathrm{nBu} 4 \mathrm{NBr}(12 \mathrm{mg}, 0.04 \mathrm{mmol})$ and $\mathrm{Na}_{2} \mathrm{~S} \cdot 9 \mathrm{H}_{2} \mathrm{O}(26 \mathrm{mg}$, $0.11 \mathrm{mmol}$ ). The reaction mixture was stirred at $80{ }^{\circ} \mathrm{C}$ in liquid alloy bath under Ar for $1 \mathrm{~h}$, then the reaction mixture was poured into water and was extracted with dichloromethane $(30 \mathrm{~mL} \times 3)$. Organic layers were combined, dried over anhydrous $\mathrm{Na}_{2} \mathrm{SO}_{4}$, and organic solvent was removed under vacuum. The crude product was purified by column chromatographically (silica; petroleum ether/ dichloromethane; 1:1 $\mathrm{v} / \mathrm{v}$ ), from which the desired product $\mathbf{B} 2$ as a dark violet solid was obtained (55 $\mathrm{mg}$, 84\%). ${ }^{1} \mathrm{H}$ NMR (500 MHz, $\left.\mathrm{CDCl}_{3}\right) \delta: 7.91$ (s, 2H), 6.95 (s, 4H), 6.64 (d, J = 4.1 Hz, $2 \mathrm{H}), 6.61(\mathrm{~d}, J=4.3 \mathrm{~Hz}, 2 \mathrm{H}), 6.51-6.44(\mathrm{~m}, 4 \mathrm{H}), 2.35(\mathrm{~s}, 6 \mathrm{H}), 2.11(\mathrm{~s}, 12 \mathrm{H}) .{ }^{13} \mathrm{C} \mathrm{NMR}$ $\left(126 \mathrm{MHz}, \mathrm{CDCl}_{3}\right) \delta: 149.9,144.7,144.3,138.9,136.9,136.5,135.5,129.5,129.4$, 129.4, 128.2, 122.7, 118.8, 21.1, 20.0. HRMS (ESI) calcd. for $\mathrm{C}_{36} \mathrm{H}_{32} \mathrm{~B}_{2} \mathrm{~F}_{4} \mathrm{~N}_{4} \mathrm{~S}^{+}$, [M-F] $]^{+}$: 631.2480, found 631.2484.
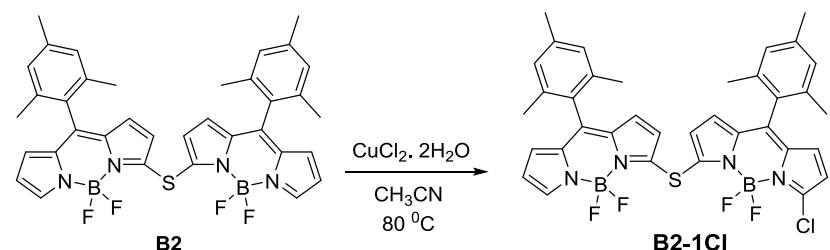

Synthesis of BODIPY B2-1Cl: A mixture of BODIPY B2 (65 mg, $0.1 \mathrm{mmol})$ and $\mathrm{CuCl}_{2} \cdot 2 \mathrm{H}_{2} \mathrm{O}(102 \mathrm{mg}, 0.6 \mathrm{mmol})$ in $\mathrm{CH}_{3} \mathrm{CN}(20 \mathrm{~mL})$ was stirred under air at $80{ }^{\circ} \mathrm{C}$ in liquid alloy bath for $2 \mathrm{~h}$. After cooling down to room temperature, the reaction mixture was poured in dichloromethane $(100 \mathrm{~mL})$, washed with water $(3 \times 50 \mathrm{~mL})$, dried over anhydrous $\mathrm{Na}_{2} \mathrm{SO}_{4}$, filtered and evaporated under vacuum. The crude product was purified by column chromatography (silica; petroleum ether/ dichloromethane; $1: 1 \mathrm{v} / \mathrm{v}$ ), from which the desired product B2-1Cl as a dark violet solid was obtained (34 $\mathrm{mg}$, 
53\%). ${ }^{1} \mathrm{H}$ NMR $\left(500 \mathrm{MHz}, \mathrm{CDCl}_{3}\right) \delta: 7.92(\mathrm{~s}, 1 \mathrm{H}), 6.94(\mathrm{~d}, J=3.7 \mathrm{~Hz}, 4 \mathrm{H}), 6.65(\mathrm{~d}, J$ $=4.1 \mathrm{~Hz}, 1 \mathrm{H}), 6.61(\mathrm{~d}, J=4.3 \mathrm{~Hz}, 1 \mathrm{H}), 6.57(\mathrm{dd}, J=7.9,4.4 \mathrm{~Hz}, 2 \mathrm{H}), 6.49(\mathrm{dd}, J=5.8$, $3.1 \mathrm{~Hz}, 2 \mathrm{H}), 6.46(\mathrm{~d}, J=4.4 \mathrm{~Hz}, 1 \mathrm{H}), 6.35(\mathrm{~d}, J=4.3 \mathrm{~Hz}, 1 \mathrm{H}), 2.35(\mathrm{~d}, J=3.8 \mathrm{~Hz}, 6 \mathrm{H})$, $2.10(\mathrm{~d}, J=2.2 \mathrm{~Hz}, 12 \mathrm{H}) .{ }^{13} \mathrm{C} \mathrm{NMR}\left(126 \mathrm{MHz}, \mathrm{CDCl}_{3}\right) \delta: 151.7,149.4,145.4,145.1$, 144.4, 143.0, 139.5, 139.4, 137.3, 137.1, 136.9, 136.0, 134.7, 130.1, 129.8, 129.7, 129.1, 128.7, 128.6, 123.5, 123.3, 119.4, 119.0, 21.5, 20.4, 20.4. HRMS (ESI) calcd. for $\mathrm{C}_{36} \mathrm{H}_{30} \mathrm{~B}_{2} \mathrm{ClF}_{3} \mathrm{~N}_{4} \mathrm{~S}^{+},[\mathrm{M}-\mathrm{F}]^{+}:$665.2091, found 665.2096.
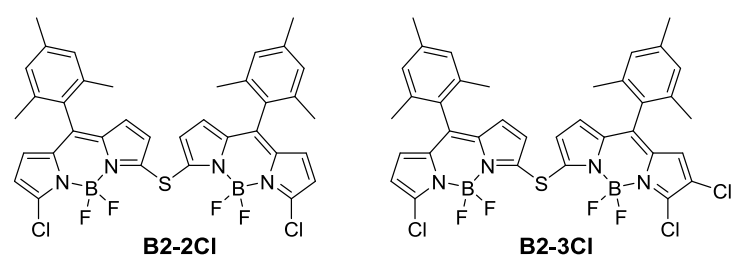

BODIPY B2-2Cl and B2-3Cl were obtained from BODIPY B2 using the same procedure described for $\mathbf{B 2}-\mathbf{1 C l}$, but the $\mathrm{CuCl}_{2} .2 \mathrm{H}_{2} \mathrm{O}(136 \mathrm{mg}, 0.8 \mathrm{mmol})$ was used, and this reaction was completed after $5 \mathrm{~h}$, providing a dark violet solid B2-2Cl (33 mg, 46\%) and a dark violet solid B2-3Cl (14 mg, 19\%).

B2-2Cl: ${ }^{1} \mathrm{H}$ NMR $\left(500 \mathrm{MHz}, \mathrm{CDCl}_{3}\right) \delta: 6.94(\mathrm{~s}, 4 \mathrm{H}), 6.58(\mathrm{~d}, J=4.1 \mathrm{~Hz}, 4 \mathrm{H}), 6.48(\mathrm{~d}$, $J=4.3 \mathrm{~Hz}, 2 \mathrm{H}), 6.36(\mathrm{~d}, J=4.3 \mathrm{~Hz}, 2 \mathrm{H}), 2.35(\mathrm{~s}, 6 \mathrm{H}), 2.10(\mathrm{~s}, 12 \mathrm{H}) .{ }^{13} \mathrm{C}$ NMR $(126$ $\left.\mathrm{MHz}, \mathrm{CDCl}_{3}\right) \delta: 150.2,144.5,142.9,139.1,136.6,134.4,129.6,129.3,128.6,128.3$, 123.3, 118.8, 21.1, 20.0. HRMS (ESI) calcd. for $\mathrm{C}_{36} \mathrm{H}_{30} \mathrm{~B}_{2} \mathrm{Cl}_{2} \mathrm{~F}_{3} \mathrm{~N}_{4} \mathrm{~S}^{+}$, [M-F] ${ }^{+}$: 699.1701, found 699.1707 .

B2-3Cl: ${ }^{1} \mathrm{H}$ NMR $\left(500 \mathrm{MHz}, \mathrm{CDCl}_{3}\right) \delta 6.95(\mathrm{~d}, J=6.7 \mathrm{~Hz}, 4 \mathrm{H}), 6.65(\mathrm{~d}, J=4.4 \mathrm{~Hz}$, $1 \mathrm{H}), 6.62-6.60(\mathrm{~m}, 2 \mathrm{H}), 6.57(\mathrm{~d}, J=4.3 \mathrm{~Hz}, 1 \mathrm{H}), 6.45(\mathrm{~s}, 1 \mathrm{H}), 6.40(\mathrm{dd}, J=4.3,2.1 \mathrm{~Hz}$, 2H), 2.35 (s, 3H), 2.34 (s, 3H), 2.10 (s, 12H). $\left.{ }^{13} \mathrm{C} \mathrm{NMR} \mathrm{(126} \mathrm{MHz,} \mathrm{CDCl}_{3}\right) \delta$ 156.1, $146.8,146.7,144.3,142.3,139.7,139.3,137.6,137.1,137.0,135.4,131.8,131.2,131.1$, $129.3,128.8,128.8,128.6,124.7,124.4,123.5,120.3,120.1,21.5,20.4$. HRMS (MALDI-TOF) calcd. for $\mathrm{C}_{36} \mathrm{H}_{29} \mathrm{~B}_{2} \mathrm{Cl}_{3} \mathrm{~F}_{4} \mathrm{~N}_{4} \mathrm{~S}[\mathrm{M}]^{+}:$754.1270, found 754.1259.

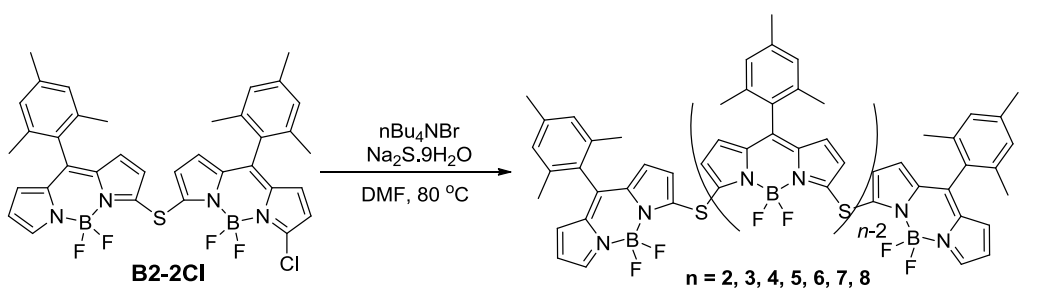


General method for the preparation of BODIPYs B2-B8: To a solution of B2-1Cl (136 mg, $0.2 \mathrm{mmol})$ in DMF $(10 \mathrm{~mL})$ was added water $(0.1 \mathrm{~mL}), \mathrm{nBu}_{4} \mathrm{NBr}(12 \mathrm{mg}$, $0.04 \mathrm{mmol})$ and $\mathrm{Na}_{2} \mathrm{~S} \cdot 9 \mathrm{H}_{2} \mathrm{O}(26 \mathrm{mg}, 0.11 \mathrm{mmol})$. The reaction mixture was stirred at $80{ }^{\circ} \mathrm{C}$ in liquid alloy bath under Ar for $1 \mathrm{~h}$, then the reaction mixture was poured into water and was extracted with dichloromethane $(60 \mathrm{~mL} \times 3)$. Organic layers were combined, dried over anhydrous $\mathrm{Na}_{2} \mathrm{SO}_{4}$, and organic solvent was removed under vacuum. The crude product was purified by column chromatographically (silica; petroleum ether/ dichloromethane; $1: 1-1: 5 \mathrm{v} / \mathrm{v})$.

BODIPY dimer B2 as a dark violet solid (7 mg, 5\%) after silica column chromatography (silica, petroleum ether/dichloromethane: 1:1, v/v). Because it is the recycled raw materials, detailed NMR data and mass spectra are not listed.

BODIPY trimer B3 as a dark violet solid (50 $\mathrm{mg}, 38 \%$ ) after silica column chromatography (silica, petroleum ether/dichloromethane: 1:2, v/v). ${ }^{1} \mathrm{H}$ NMR (500 $\left.\mathrm{MHz}, \mathrm{CDCl}_{3}\right) \delta 7.91(\mathrm{~s}, 2 \mathrm{H}), 6.94(\mathrm{~d}, J=4.6 \mathrm{~Hz}, 6 \mathrm{H}), 6.63(\mathrm{~d}, J=4.1 \mathrm{~Hz}, 2 \mathrm{H}), 6.60(\mathrm{~d}$, $J=4.3 \mathrm{~Hz}, 2 \mathrm{H}), 6.55(\mathrm{~d}, J=4.3 \mathrm{~Hz}, 2 \mathrm{H}), 6.47(\mathrm{~d}, J=4.2 \mathrm{~Hz}, 4 \mathrm{H}), 6.45(\mathrm{~d}, J=4.3 \mathrm{~Hz}$, $2 \mathrm{H}), 2.35(\mathrm{~d}, J=6.0 \mathrm{~Hz}, 9 \mathrm{H}), 2.11(\mathrm{~d}, J=2.6 \mathrm{~Hz}, 18 \mathrm{H}) .{ }^{13} \mathrm{C} \mathrm{NMR}\left(126 \mathrm{MHz}, \mathrm{CDCl}_{3}\right)$ $\delta 150.4,150.3,145.0,144.7,141.5,139.4,139.3,137.5,137.4,137.1,136.9,135.9$, $129.8,129.8,129.5,128.9,128.7,128.6,123.8,123.3,119.2,21.5,20.5,20.5$. HRMS (MALDI-TOF) calcd. for $\mathrm{C}_{54} \mathrm{H}_{47} \mathrm{~B}_{3} \mathrm{~F}_{6} \mathrm{~N}_{6} \mathrm{~S}_{2}$, [M] ${ }^{+}$: 990.3487, found 990.3482.

BODIPY tetramer B4 as a dark violet solid (28 mg, 21\%) after silica column chromatography (silica, petroleum ether/dichloromethane: 1:2, v/v). ${ }^{1} \mathrm{H}$ NMR (500 $\left.\mathrm{MHz}, \mathrm{CDCl}_{3}\right) \delta 7.90(\mathrm{~s}, 2 \mathrm{H}), 6.94(\mathrm{~d}, J=2.4 \mathrm{~Hz}, 8 \mathrm{H}), 6.62(\mathrm{~d}, J=3.6 \mathrm{~Hz}, 2 \mathrm{H}), 6.59(\mathrm{~d}$, $J=4.3 \mathrm{~Hz}, 2 \mathrm{H}), 6.53(\mathrm{~d}, J=4.3 \mathrm{~Hz}, 4 \mathrm{H}), 6.48-6.43(\mathrm{~m}, 8 \mathrm{H}), 2.34(\mathrm{~d}, J=3.1 \mathrm{~Hz}, 12 \mathrm{H})$, $2.11(\mathrm{~d}, J=3.2 \mathrm{~Hz}, 24 \mathrm{H}) .{ }^{13} \mathrm{C}$ NMR $\left(126 \mathrm{MHz}, \mathrm{CDCl}_{3}\right) \delta 150.6,150.4,150.2,145.0$, 144.6, 141.3, 139.3, 139.2, 137.7, 137.6, 137.4, 137.1, 137.0, 135.9, 129.9, 129.8, 129.6, $129.5,128.8,128.6,128.6,124.2,123.9,123.5,119.1,21.5,20.5,20.5$. HRMS (MALDI-TOF) calcd. for $\mathrm{C}_{72} \mathrm{H}_{62} \mathrm{~B}_{4} \mathrm{~F}_{8} \mathrm{~N}_{8} \mathrm{~S}_{3},[\mathrm{M}]^{+}$: 1330.4504 , found 1330.4497.

BODIPY pentamer B5 as a black power (12 mg, 9\%) after silica column chromatography (silica, petroleum ether/dichloromethane: 1:3, v/v). ${ }^{1} \mathrm{H}$ NMR (500 
$\left.\mathrm{MHz}, \mathrm{CDCl}_{3}\right) \delta 7.89(\mathrm{~s}, 2 \mathrm{H}), 6.94(\mathrm{~d}, J=4.6 \mathrm{~Hz}, 10 \mathrm{H}), 6.62(\mathrm{~d}, J=3.8 \mathrm{~Hz}, 2 \mathrm{H}), 6.59$ $(\mathrm{d}, J=4.3 \mathrm{~Hz}, 2 \mathrm{H}), 6.54-6.52(\mathrm{~m}, 6 \mathrm{H}), 6.46(\mathrm{~d}, J=4.3 \mathrm{~Hz}, 4 \mathrm{H}), 6.43(\mathrm{t}, J=4.7 \mathrm{~Hz}$, $6 \mathrm{H}), 2.34(\mathrm{~d}, J=5.7 \mathrm{~Hz}, 15 \mathrm{H}), 2.11(\mathrm{~d}, J=2.3 \mathrm{~Hz}, 30 \mathrm{H}) .{ }^{13} \mathrm{C} \mathrm{NMR}\left(126 \mathrm{MHz}, \mathrm{CDCl}_{3}\right)$ $\delta 151.0,150.8,150.3,149.8,144.9,144.4,141.2,141.0,139.3,139.2,137.8,137.8$, 137.6, 137.4, 137.2, 137.0, 135.8, 129.9, 129.8, 129.5, 128.9, 128.6, 128.6, 124.4, 124.0, 123.5, 119.0, 21.5, 20.6, 20.5. HRMS (MALDI-TOF) calcd. for $\mathrm{C}_{90} \mathrm{H}_{77} \mathrm{~B}_{5} \mathrm{~F}_{10} \mathrm{~N}_{10} \mathrm{~S}_{4}$, $[\mathrm{M}]^{+}:$1670.5581, found 1670.5560 .

BODIPY hexamer B6 as black power (6 mg, 4\%) after silica column chromatography (silica, petroleum ether/dichloromethane: 1:4, v/v). ${ }^{1} \mathrm{H}$ NMR $\left(500 \mathrm{MHz}, \mathrm{CDCl}_{3}\right) \delta 7.89$ (s, 2H), $6.93(\mathrm{~s}, 12 \mathrm{H}), 6.60(\mathrm{dd}, J=10.0,3.9 \mathrm{~Hz}, 4 \mathrm{H}), 6.55-6.51(\mathrm{~m}, 8 \mathrm{H}), 6.47$ (d, $J=$ $4.0 \mathrm{~Hz}, 4 \mathrm{H}), 6.43(\mathrm{dd}, J=8.7,4.2 \mathrm{~Hz}, 8 \mathrm{H}), 2.34(\mathrm{~d}, J=3.8 \mathrm{~Hz}, 18 \mathrm{H}), 2.11(\mathrm{~d}, J=3.2$ $\mathrm{Hz}, 36 \mathrm{H}) .{ }^{13} \mathrm{C} \mathrm{NMR}\left(126 \mathrm{MHz}, \mathrm{CDCl}_{3}\right) \delta 151.5,151.3,151.2,150.6,150.2,149.8$, 149.4, 144.8, 144.3, 144.2, 141.1, 140.8, 139.3, 139.2, 139.2, 138.0, 137.9, 137.6, 137.4, 137.2, 137.2 137.0, 135.8, 129.9, 129.8, 129.5, 128.9, 128.6, 128.6, 128.5, 124.6, 124.5, 124.1, 123.4, 119.0, 21.5, 20.6, 20.5. HRMS (MALDI-TOF) calcd. for $\mathrm{C}_{108} \mathrm{H}_{92} \mathrm{~B}_{6} \mathrm{~F}_{12} \mathrm{~N}_{12} \mathrm{~S}_{5},[\mathrm{M}]^{+}:$2010.6538, found 2010.6595 .

Small amounts of heptamer B7 and octamer B8 (Figure S1) were also isolated in about 2-5\% yields from the above reaction, which were only characterized by HRMS (MALDI spectra). B7: HRMS (MALDI-TOF) calcd. for $\mathrm{C}_{126} \mathrm{H}_{107} \mathrm{~B}_{7} \mathrm{~F}_{14} \mathrm{~N}_{14} \mathrm{~S}_{6},[\mathrm{M}]^{+}$: 2350.7555, found 2350.7515. B8: HRMS (MALDI-TOF) calcd. for $\mathrm{C}_{144} \mathrm{H}_{122} \mathrm{~B}_{8} \mathrm{~F}_{16} \mathrm{~N}_{16} \mathrm{~S}_{7},[\mathrm{M}]^{+}:$2690.8572, found 2690.8590 . 


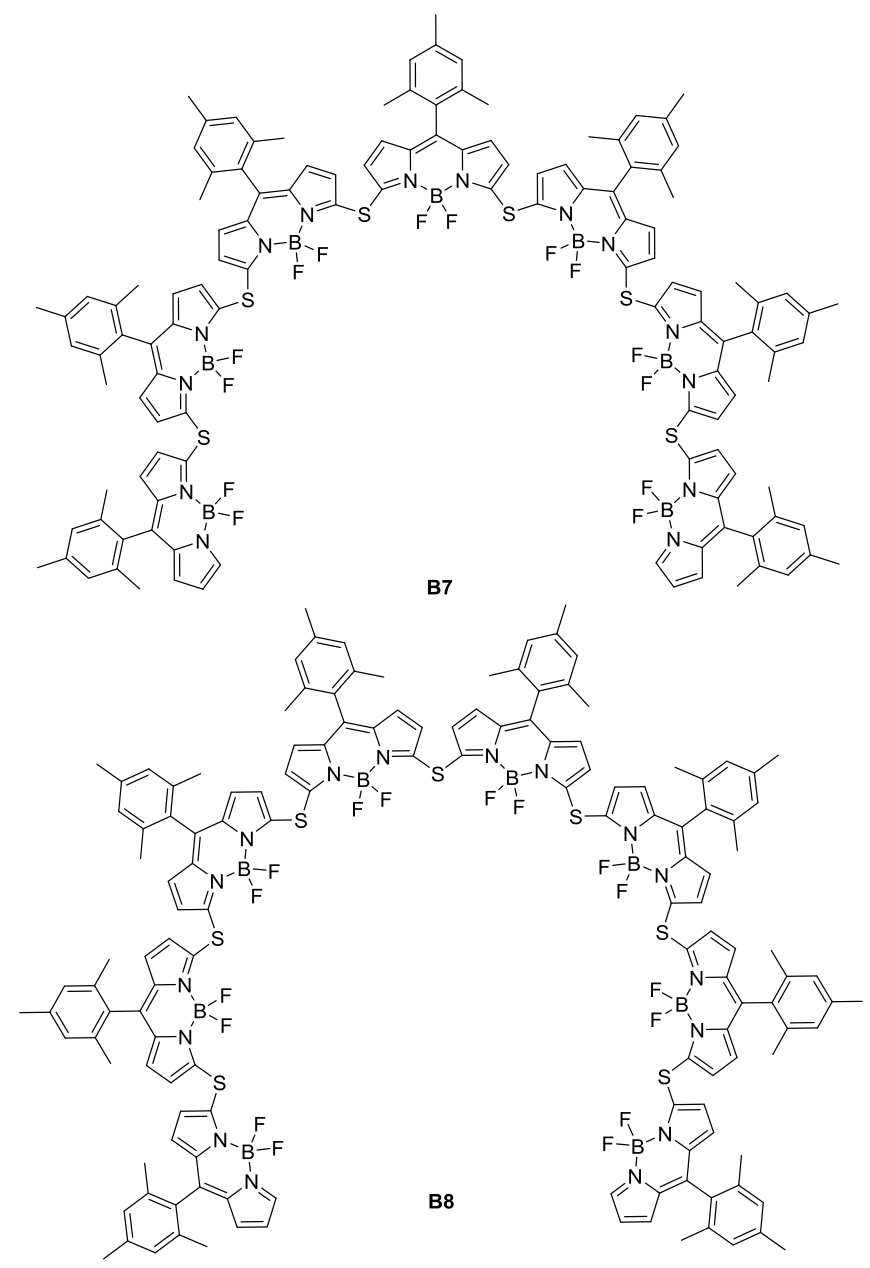

Figure S1. Chemical structures of heptamer B7 and octamer B8 


\section{Photophysical Properties}

Table S4: Photophysical properties of B2-B6 in different solvents at room temperature.

(Data of starting BODIPYs B1 and B1-Cl in toluene were included for comparison).

\begin{tabular}{|c|c|c|c|c|}
\hline entry & solvent & $\lambda_{\mathrm{abs}}{ }^{\mathrm{a}} / \mathrm{nm}\left(\varepsilon^{\mathrm{b}}\right)$ & $\lambda_{\mathrm{em}}{ }^{\max } / \mathrm{nm}\left(\Phi^{\mathrm{c}}\right)$ & $\mathrm{SS}^{\mathrm{d}}$ \\
\hline B1 & toluene & $502(58)$ & $516(0.90)$ & 540 \\
\hline B1-Cl & toluene & $509(64)$ & $521(0.88)$ & 450 \\
\hline \multirow{6}{*}{ B2 } & hexane & $623(124)$ & $631(0.30)$ & 200 \\
\hline & toluene & $627(90)$ & $640(0.06)$ & 320 \\
\hline & DCM & $618(72)$ & $632(0.002)$ & 350 \\
\hline & THF & $621(110)$ & $636(0.003)$ & 380 \\
\hline & acetonitrile & $610(65), 546(59)$ & 624 (n.d. $\left.{ }^{e}\right)$ & 360 \\
\hline & methanol & $613(86)$ & $625(0.001)$ & 310 \\
\hline \multirow{6}{*}{ B2-1Cl } & hexane & $632(133)$ & $640(0.18)$ & 200 \\
\hline & toluene & $636(97)$ & $647(0.04)$ & 260 \\
\hline & DCM & $626(80)$ & $640(0.002)$ & 350 \\
\hline & THF & $628(106)$ & $642(0.002)$ & 340 \\
\hline & acetonitrile & $618(56), 550(52)$ & $630\left(\right.$ n.d..$\left.^{\mathrm{e}}\right)$ & 300 \\
\hline & methanol & $620(81)$ & 633 (n.d. ${ }^{\mathrm{e}}$ ) & 330 \\
\hline \multirow{6}{*}{ B2-2Cl } & hexane & $640(144)$ & $647(0.20)$ & 170 \\
\hline & toluene & 644 (104) & $654(0.05)$ & 230 \\
\hline & DCM & $634(83)$ & $649(0.02)$ & 360 \\
\hline & THF & $636(115)$ & $648(0.004)$ & 290 \\
\hline & acetonitrile & $624(62), 554(55)$ & 637 (n.d. ${ }^{\mathrm{e}}$ ) & 320 \\
\hline & methanol & $628(86)$ & $639(0.001)$ & 270 \\
\hline \multirow{6}{*}{ B2-3Cl } & hexane & $648(143)$ & $658(0.07)$ & 230 \\
\hline & toluene & $652(115)$ & $665(0.02)$ & 300 \\
\hline & DCM & $642(98)$ & $657(0.001)$ & 350 \\
\hline & THF & $643(123)$ & $657(0.002)$ & 330 \\
\hline & acetonitrile & $632(78), 564(71)$ & $645\left(\right.$ n.d. $\left.{ }^{e}\right)$ & 310 \\
\hline & methanol & $635(91)$ & $646\left(\right.$ n.d. $\left.{ }^{e}\right)$ & 260 \\
\hline \multirow{6}{*}{ B3 } & hexane & $700(75, \mathrm{sh}), 655(74), 522(52)$ & $712(0.09)$ & 240 \\
\hline & toluene & $706(64, \mathrm{sh}), 662(71), 526(52)$ & $720(0.07)$ & 270 \\
\hline & DCM & $692(64, \mathrm{sh}), 650(63), 523(60)$ & $711(0.004)$ & 380 \\
\hline & THF & $698(66, \mathrm{sh}), 653(70), 524(56)$ & $713(0.007)$ & 340 \\
\hline & acetonitrile & $682(25, \mathrm{sh}), 636(46), 518(59)$ & 700 (n.d. $\left.{ }^{e}\right)$ & 370 \\
\hline & methanol & $690(46, \mathrm{sh}), 647(68), 520(56)$ & $703(0.002)$ & 260 \\
\hline \multirow{5}{*}{ B4 } & hexane & $722(40, \mathrm{sh}), 658(69), 595(82)$ & $756(0.002)$ & 620 \\
\hline & toluene & $730(54, \mathrm{sh}), 676(65), 607$ (73) & $769(0.03)$ & 690 \\
\hline & DCM & $712(39, \mathrm{sh}), 657(61), 592(72)$ & $756(0.001)$ & 810 \\
\hline & THF & $720(55, \mathrm{sh}), 667(70), 600(81)$ & $762(0.003)$ & 760 \\
\hline & acetonitrile & $696(27, \mathrm{sh}), 643(51), 583(63)$ & 738 (n.d. $\left.{ }^{e}\right)$ & 810 \\
\hline
\end{tabular}




\begin{tabular}{|c|c|c|c|c|}
\hline & methanol & $710(45, \mathrm{sh}), 656(63), 589(70)$ & 747 (n.d. $\left.{ }^{\mathrm{e}}\right)$ & 690 \\
\hline \multirow{6}{*}{ B5 } & hexane & $721(31, \mathrm{sh}), 604(75), 523(72)$ & $783(0.006)$ & 1090 \\
\hline & toluene & $735(55, \mathrm{sh}), 636(86), 535$ (72) & $796(0.025)$ & 1040 \\
\hline & DCM & $725(38, \mathrm{sh}), 606(89), 524(82)$ & $782(0.001)$ & 1000 \\
\hline & THF & $722(57, \mathrm{sh}), 634$ (92), 529 (77) & $789(0.002)$ & 1170 \\
\hline & acetonitrile & $702(27, \mathrm{sh}), 554(81), 522(79)$ & $758\left(\right.$ n.d. $\left.{ }^{\mathrm{e}}\right)$ & 1050 \\
\hline & methanol & $712(42, \mathrm{sh}), 607$ (70), $526(59)$ & 774 (n.d. $\left.{ }^{\mathrm{e}}\right)$ & 1120 \\
\hline \multirow{6}{*}{ B6 } & hexane & $597(109), 534(99, \mathrm{sh})$ & $791(0.004)$ & 4100 \\
\hline & toluene & $734(63, \mathrm{sh}), 655$ (106) & $806(0.016)$ & 2860 \\
\hline & DCM & $651(97, \mathrm{sh}), 597$ (108) & $788\left(\right.$ n.d. $\left.{ }^{e}\right)$ & 2670 \\
\hline & THF & $725(65, \mathrm{sh}), 649$ (114) & $798(0.001)$ & 2870 \\
\hline & acetonitrile & $540(101)$ & $761\left(\right.$ n.d. $\left.{ }^{e}\right)$ & 5380 \\
\hline & methanol & $612(101)$ & 806 (n.d. $\left.{ }^{e}\right)$ & 3930 \\
\hline
\end{tabular}

${ }^{a}$ Main, lowest energy absorption band [nm]. ${ }^{b}$ Molar absorption coefficient, in $10^{3} \mathrm{M}^{-1} \mathrm{~cm}^{-}$

1. ' Fluorescence quantum yield of $\mathbf{B 2}, \mathbf{B 2}-\mathbf{1 C l}, \mathbf{B 2}-2 \mathrm{Cl}$ and $\mathbf{B 2 - 3 C l}$ were calculated using Cresyl violet perchlorate ( $\Phi=0.54$ in methanol) as the reference. Fluorescence quantum yield of B3-B6 were calculated using 1,3,5,7-tetraphenyl-azadipyrromethene ( $\Phi=0.36$ in chloroform) as the reference. ${ }^{\mathrm{d}}$ Stokes shifts $\left(\mathrm{cm}^{-1}\right) .{ }^{\mathrm{e}}$ n.d. $=$ not detected. 

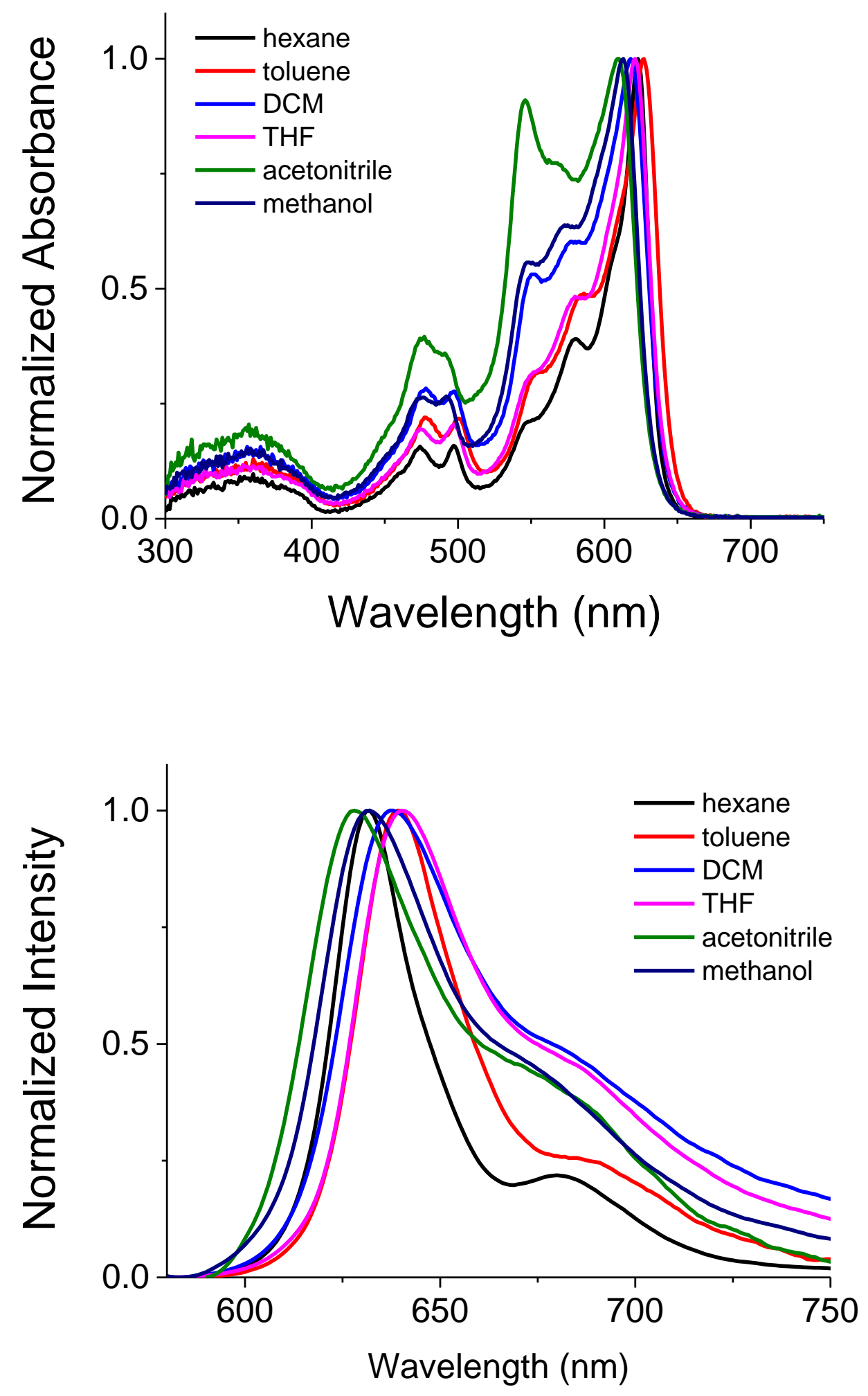

Figure S2. Normalized absorption (top) and emission (bottom) spectra of BODIPY B2 recorded in different solvents, excited at $570 \mathrm{~nm}$. 

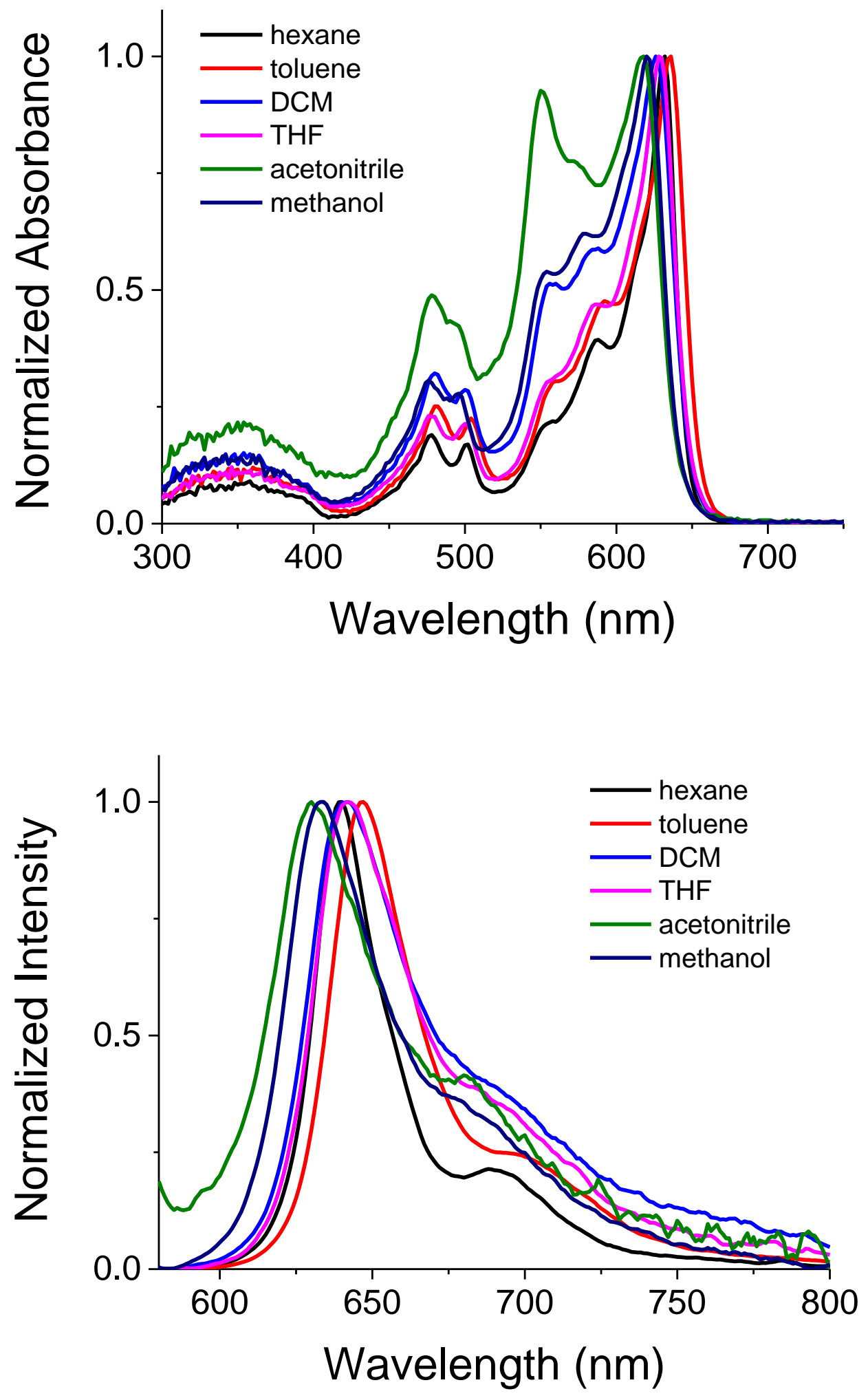

Figure S3. Normalized absorption (top) and emission (bottom) spectra of BODIPY B2-1Cl recorded in different solvents, excited at $570 \mathrm{~nm}$. 

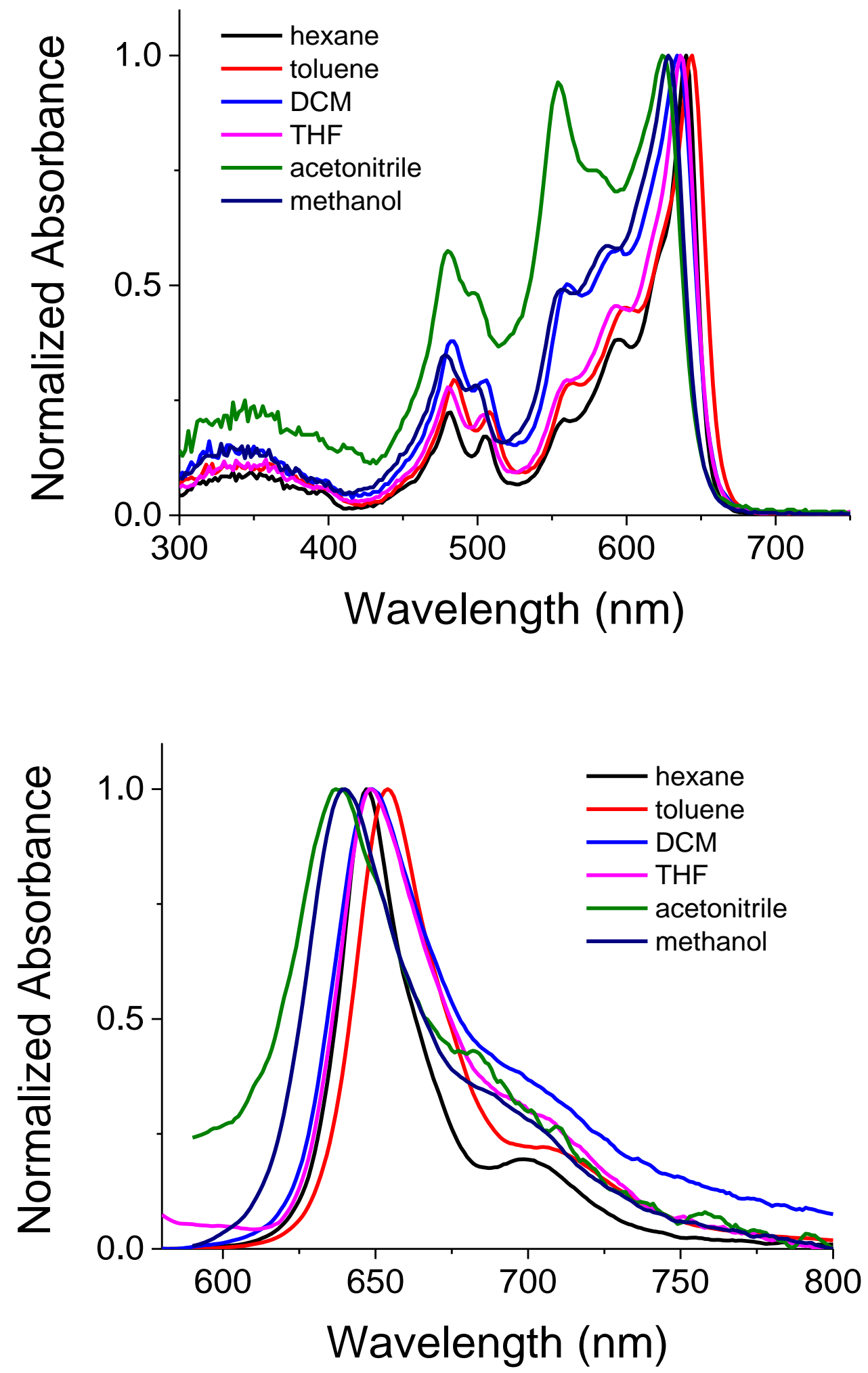

Figure S4. Normalized absorption (top) and emission (bottom) spectra of BODIPY B2-2Cl recorded in different solvents, excited at $570 \mathrm{~nm}$. 

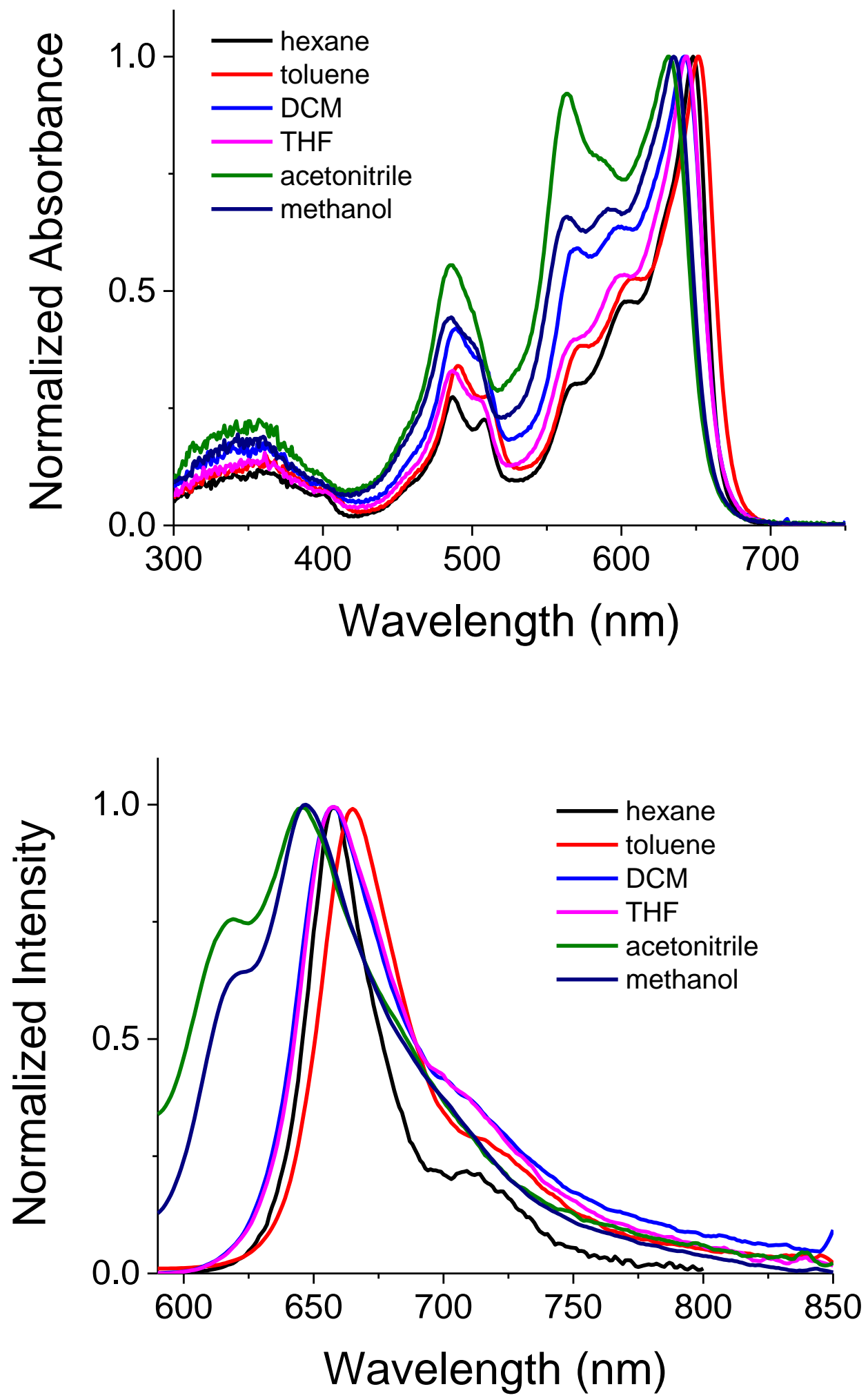

Figure S5. Normalized absorption (top) and emission (bottom) spectra of BODIPY B2-3Cl recorded in different solvents, excited at $570 \mathrm{~nm}$. 

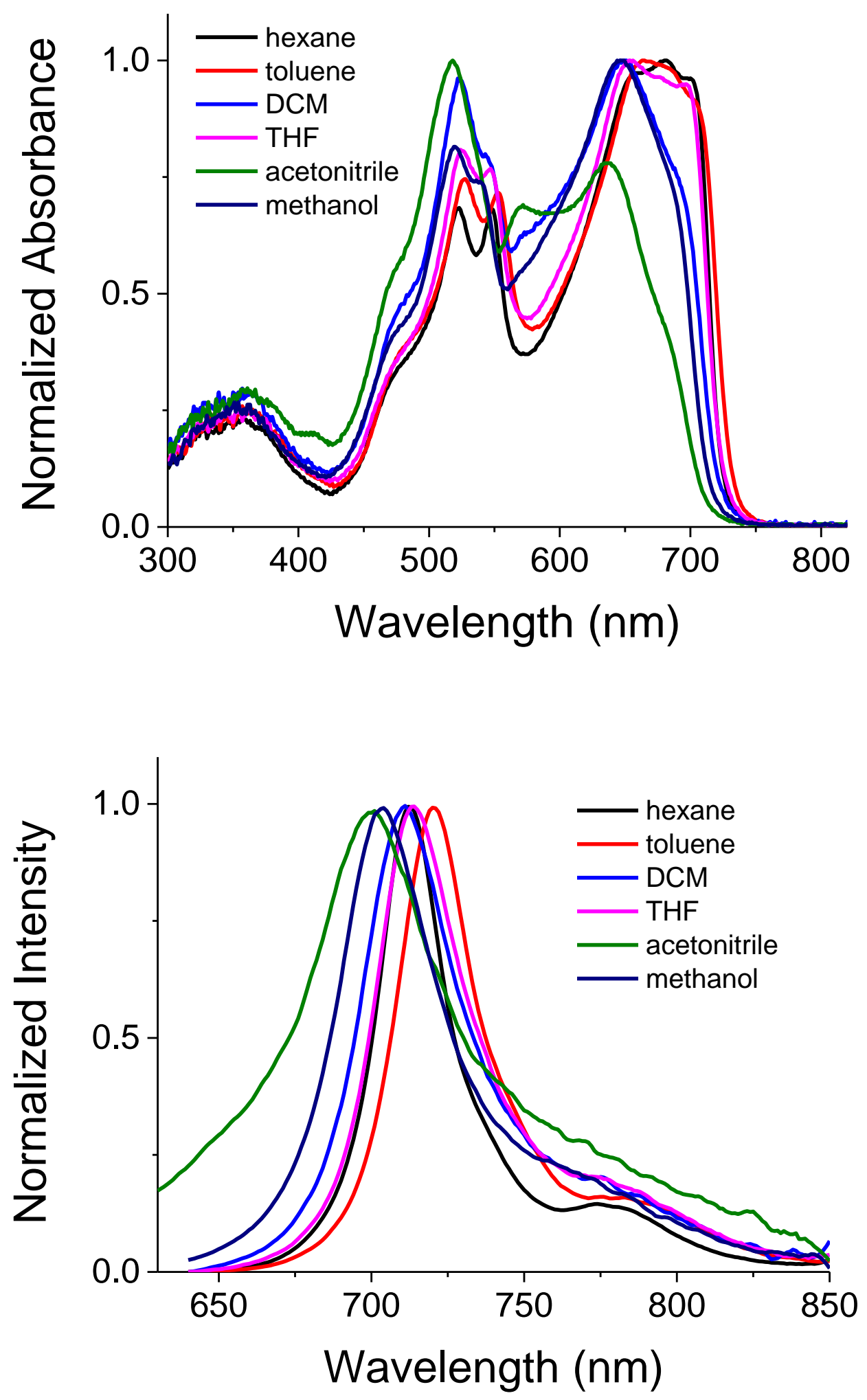

Figure S6: Absorption (top) and emission (bottom) spectra of compound $\mathbf{B 3}$ recorded in different solvents. Excited at $620 \mathrm{~nm}$. 

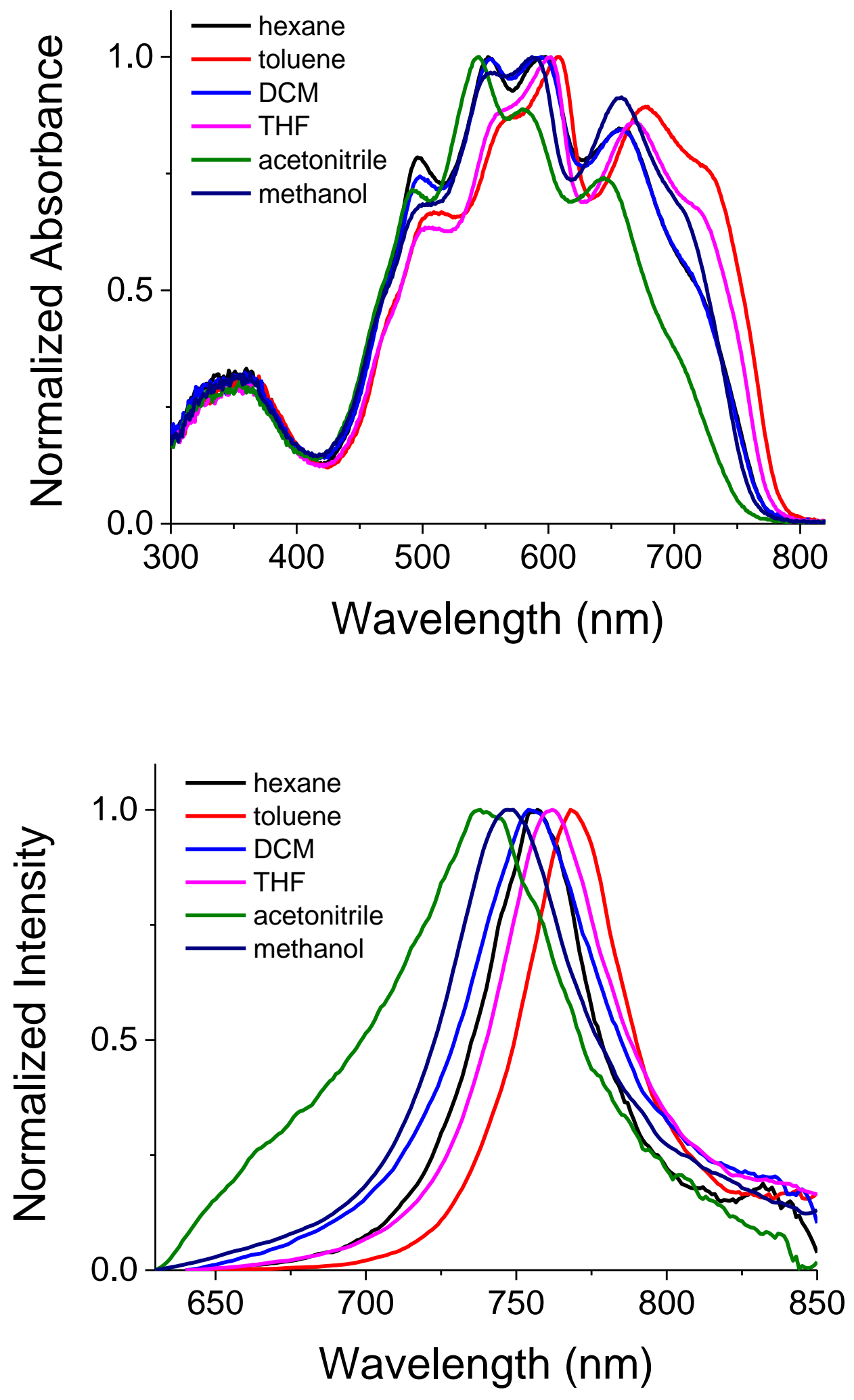

Figure S7: Absorption (top) and emission (bottom) spectra of compound B4 recorded in different solvents. Excited at $620 \mathrm{~nm}$. 

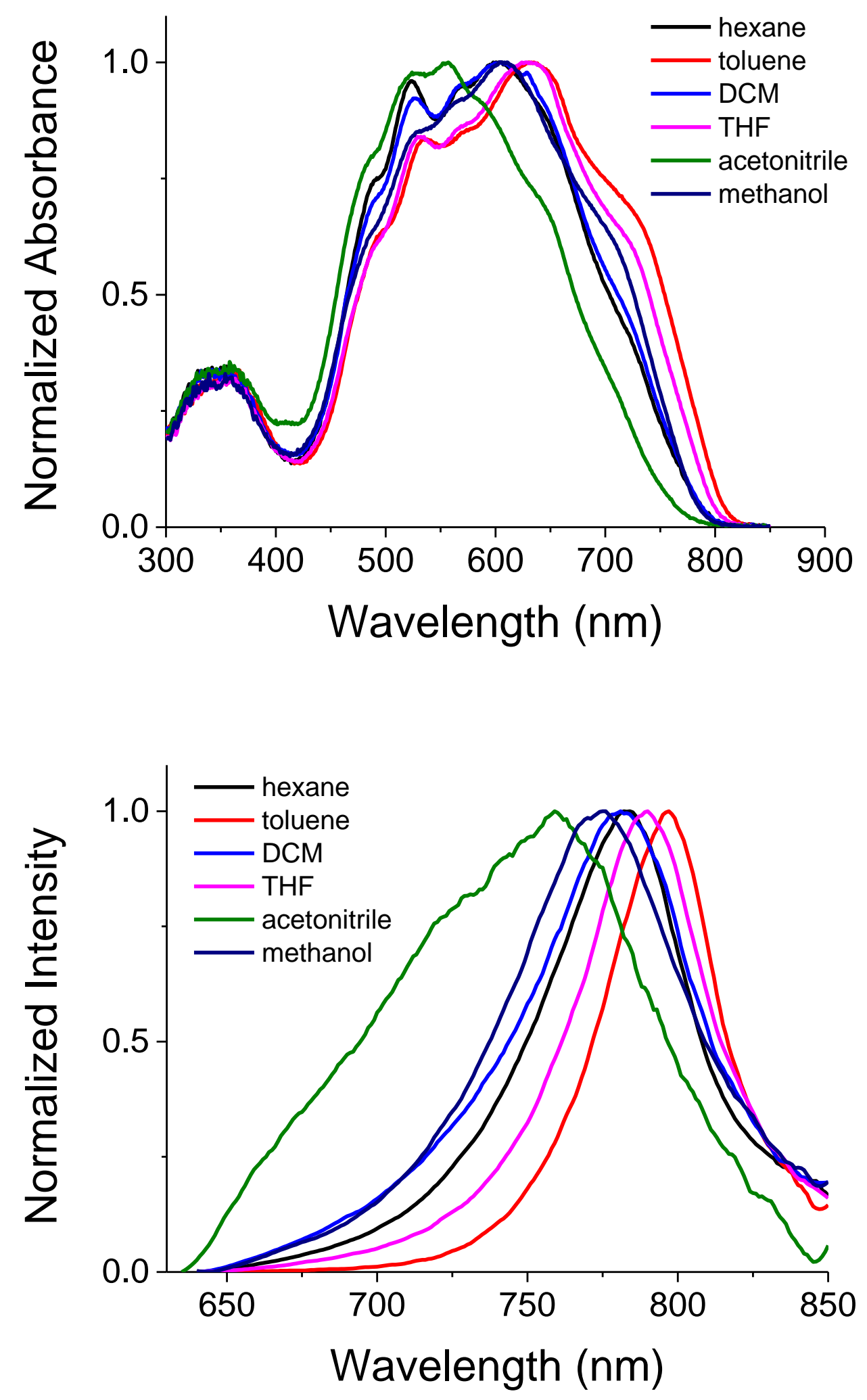

Figure S8: Absorption (top) and emission (bottom) spectra of compound B5 recorded in different solvents. Excited at $620 \mathrm{~nm}$. 

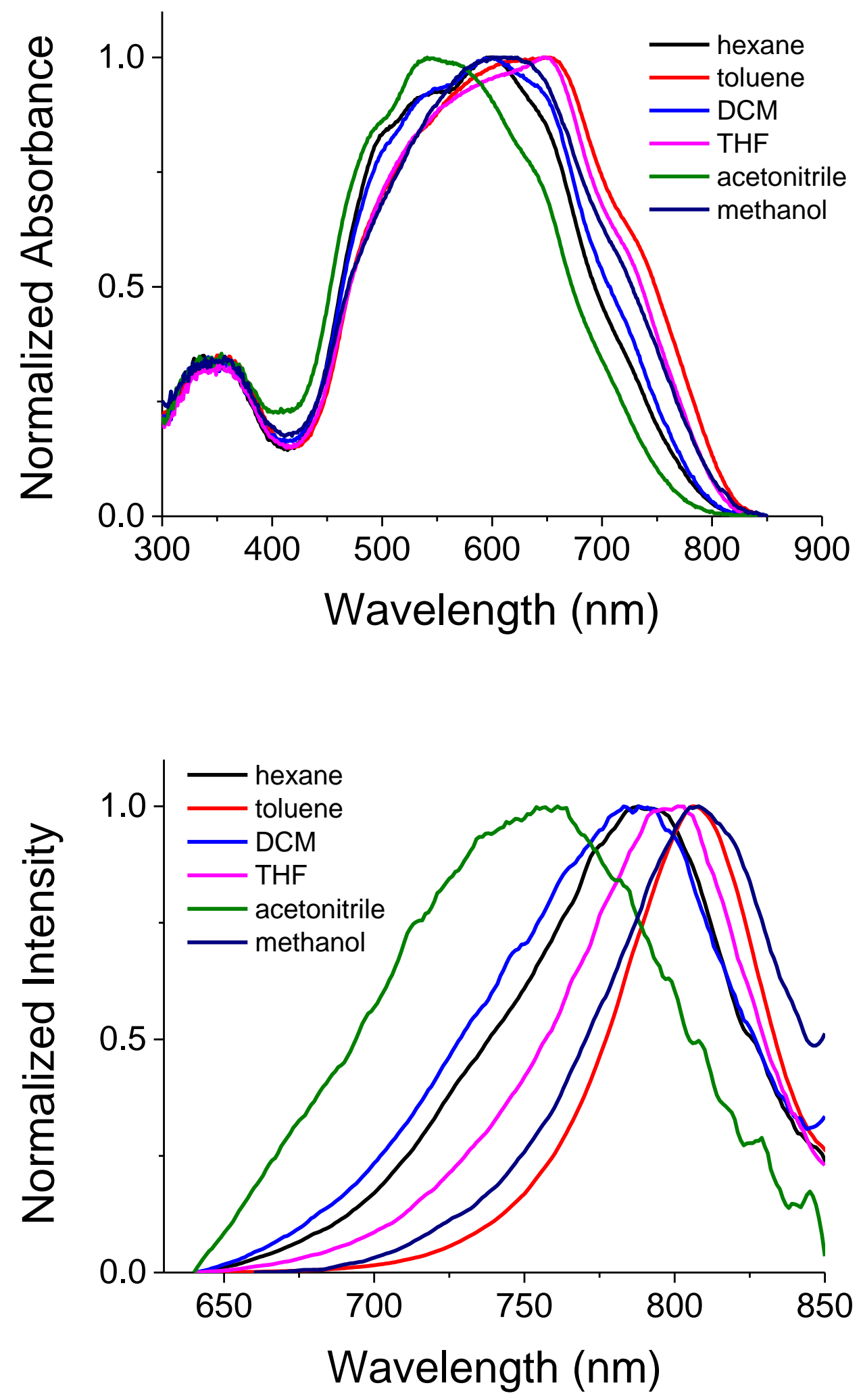

Figure S9: Absorption (top) and emission (bottom) spectra of compound B6 recorded in different solvents. Excited at $620 \mathrm{~nm}$. 


\section{Reactive Oxygen Species (ROS) Formation}

\subsection{Reactive oxygen species (ROS) yields}

A comparative study of the relative singlet oxygen generating efficiency of these dyes $\left(5 \times 10^{-6} \mathrm{M}\right)$ was performed in air-saturated solvents under light at $532 \mathrm{~nm}$ irradiation $\left(10 \mathrm{~mW} / \mathrm{cm}^{2}\right)$ condition using 1,3 diphenylisobenzofuran (DPBF, $\left.4 \times 10^{-5} \mathrm{M}\right)$ as a trap molecule. $^{8} \quad$ A wellknown photosensitizer 1,7-diphenyl-2,6-dibromo-3,5-di(4methoxyphenyl)-azaBODIPY (azaBDP) $\left(\Phi_{\Delta}=0.74 \text { in toluene }\right)^{8 \mathrm{~d}}$ was used as reference. The decrease of the absorbance band of DPBF at $415 \mathrm{~nm}$ was monitored. Singlet oxygen quantum yield $\left(\Phi_{\Delta}\right)$ determinations were carried out using the chemical trapping method. The $\Phi_{\Delta}$ value was obtained by the relative method the following equation:

$\Phi_{\Delta \mathrm{sam}}=\Phi_{\Delta \mathrm{ref}}\left[\left(\mathrm{m}_{\mathrm{sam}} / \mathrm{m}_{\mathrm{ref}}\right)\left(\mathrm{L}_{\mathrm{ref}} / \mathrm{L}_{\mathrm{sam}}\right)\right]$

Where $\Phi_{\Delta \mathrm{ref}}$ and $\Phi_{\Delta \mathrm{sam}}$ are the singlet oxygen quantum yields for the standard azaBDP and the photosensitizer (B2-B6). $\mathrm{m}_{\text {sam }}$ and $\mathrm{m}_{\text {ref }}$ are the slope of the difference $(\Delta \mathrm{OD})$ in the change in the absorption maximum wavelength of DPBF (around $415 \mathrm{~nm}$ ), which are plotted against the photoirradiation time, $\mathrm{L}_{\mathrm{ref}}$ and $\mathrm{L}_{\mathrm{sam}}$ are the light harvesting efficiency, which is given by $\mathrm{L}=1-10^{-\mathrm{A}}$ (" $\mathrm{A}$ " is the absorbance at the photoirradiation $630 \mathrm{~nm})$.

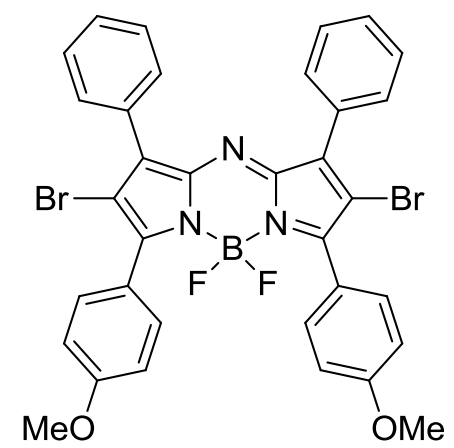

1,7-diphenyl-2,6-dibromo-3,5-di(4-methoxyphenyl)-azaBODIPY (azaBDP)

$$
\left(\Phi_{\Delta}=0.74 \text { in toluene }\right)^{8 \mathrm{~d}}
$$




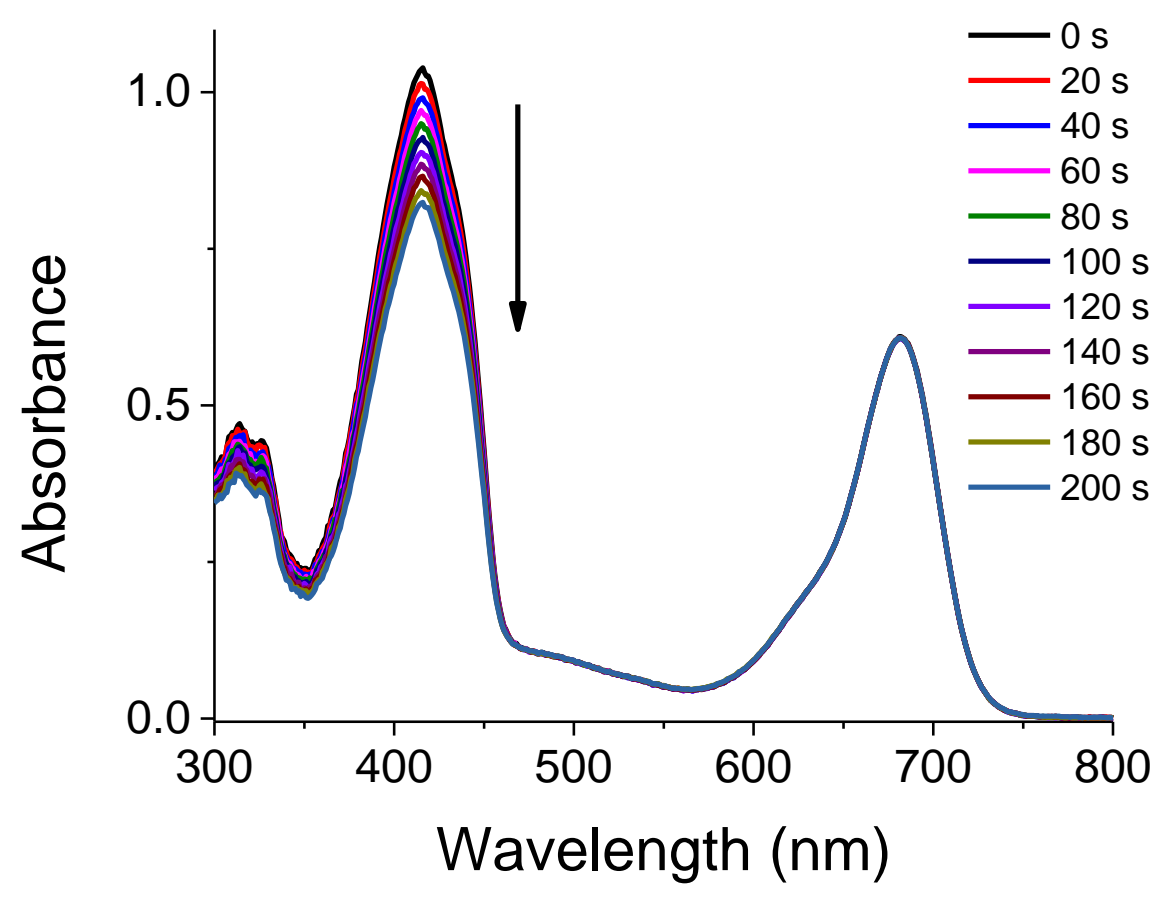

Figure S10: Absorption spectra of DPBF upon irradiation at $630 \mathrm{~nm}$ in the presence of BODIPY azaBDP in toluene.

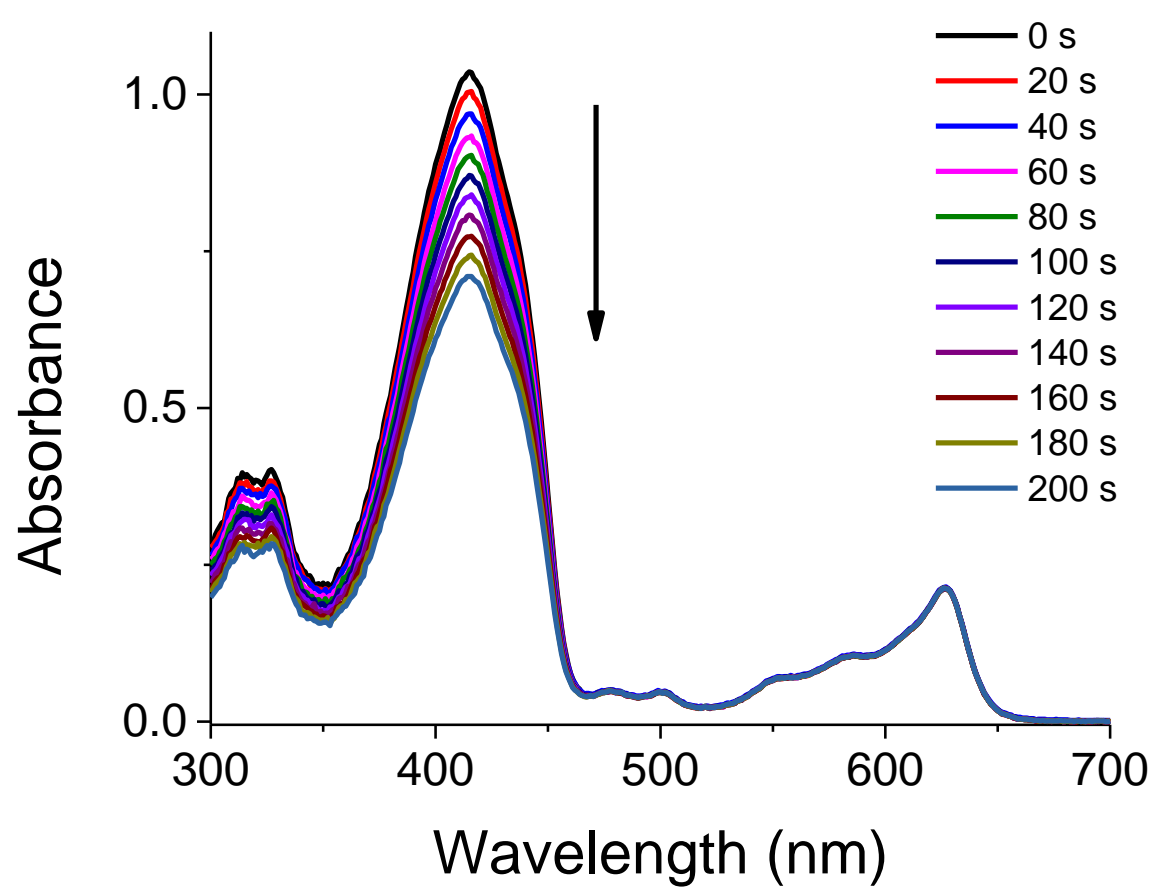

Figure S11: Absorption spectra of DPBF upon irradiation at $630 \mathrm{~nm}$ in the presence of BODIPY B2 in toluene. 


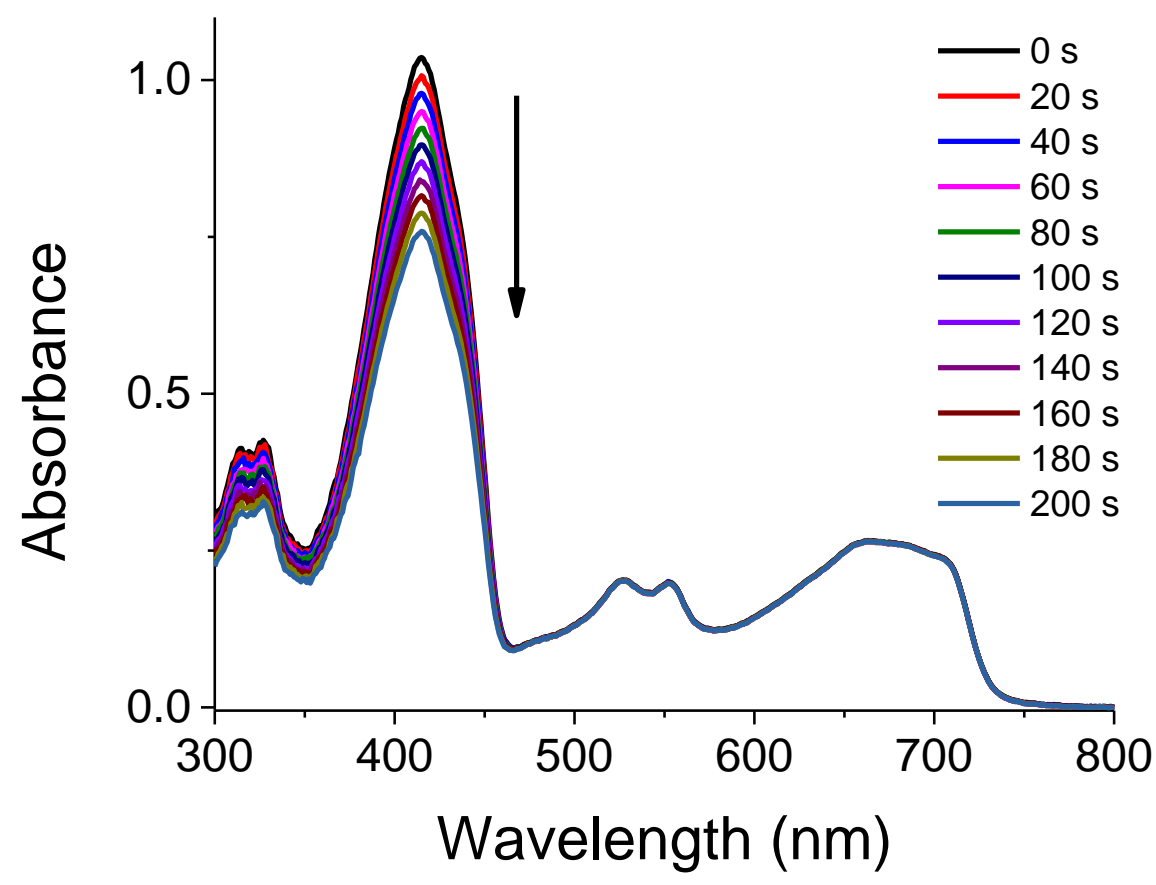

Figure S12: Absorption spectra of DPBF upon irradiation at $630 \mathrm{~nm}$ in the presence of BODIPY $\mathbf{B 3}$ in toluene.

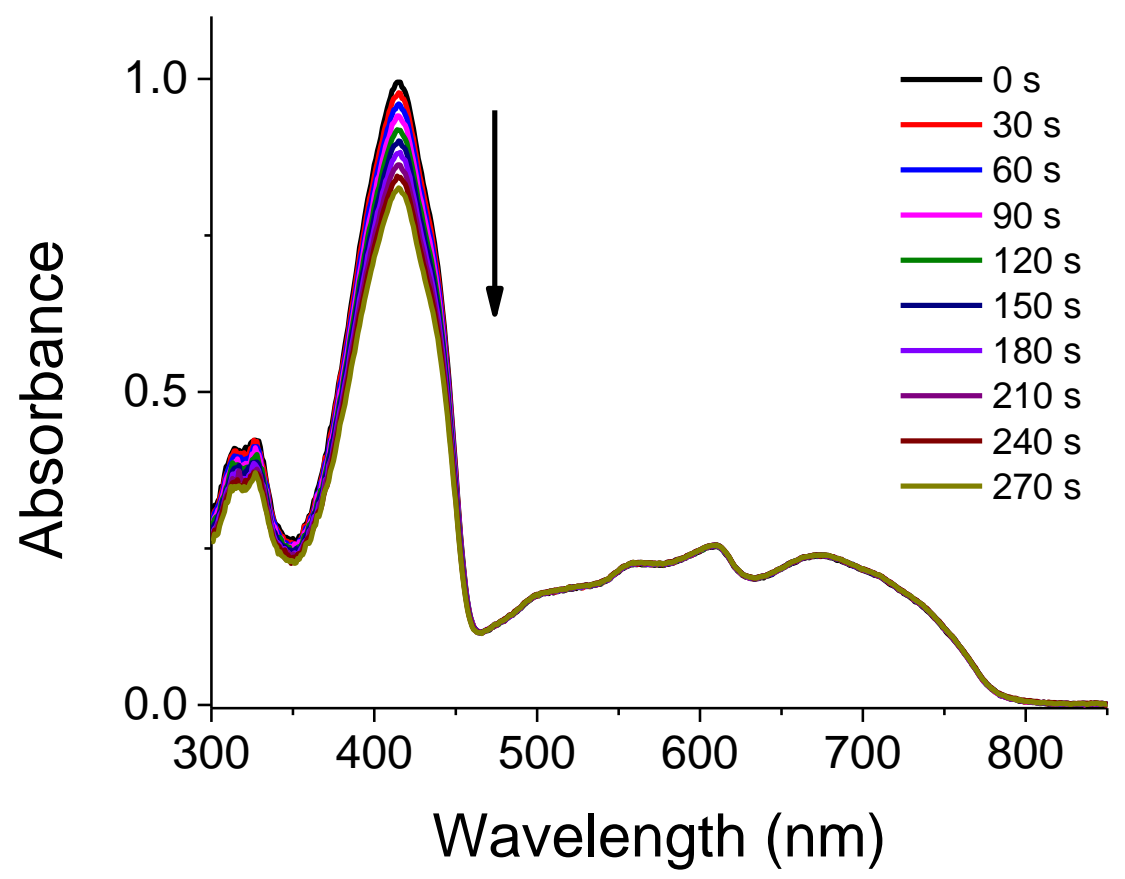

Figure S13: Absorption spectra of DPBF upon irradiation at $630 \mathrm{~nm}$ in the presence of BODIPY B4 in toluene. 


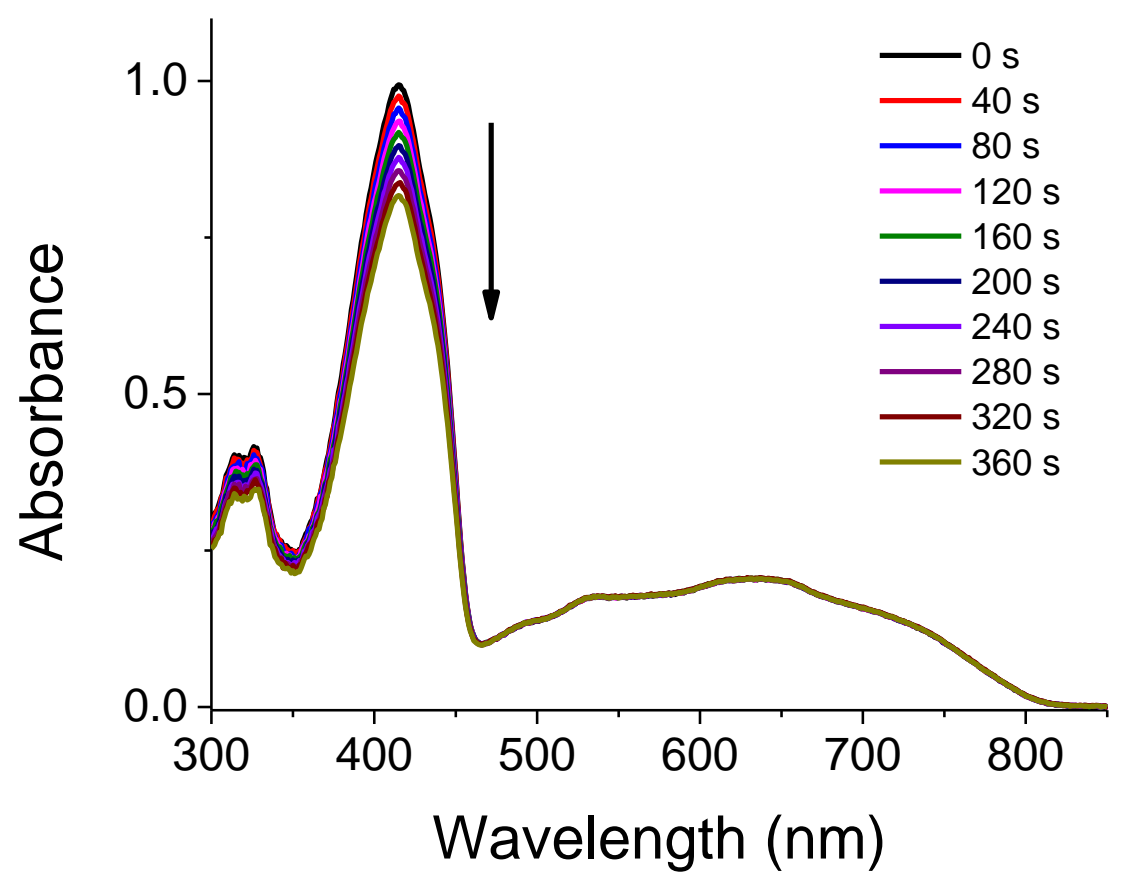

Figure S14: Absorption spectra of DPBF upon irradiation at $630 \mathrm{~nm}$ in the presence of BODIPY $\mathbf{B 5}$ in toluene.

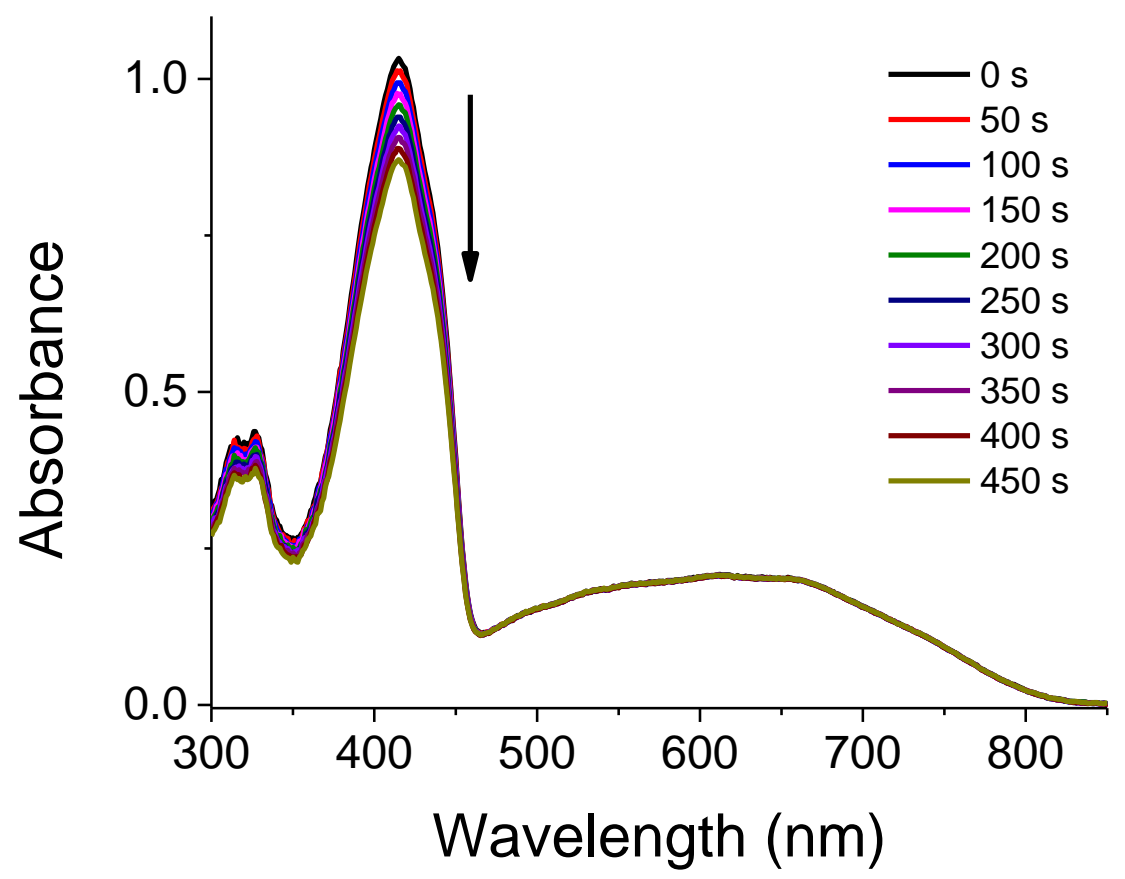

Figure S15: Absorption spectra of DPBF upon irradiation at $630 \mathrm{~nm}$ in the presence of BODIPY B6 in toluene. 


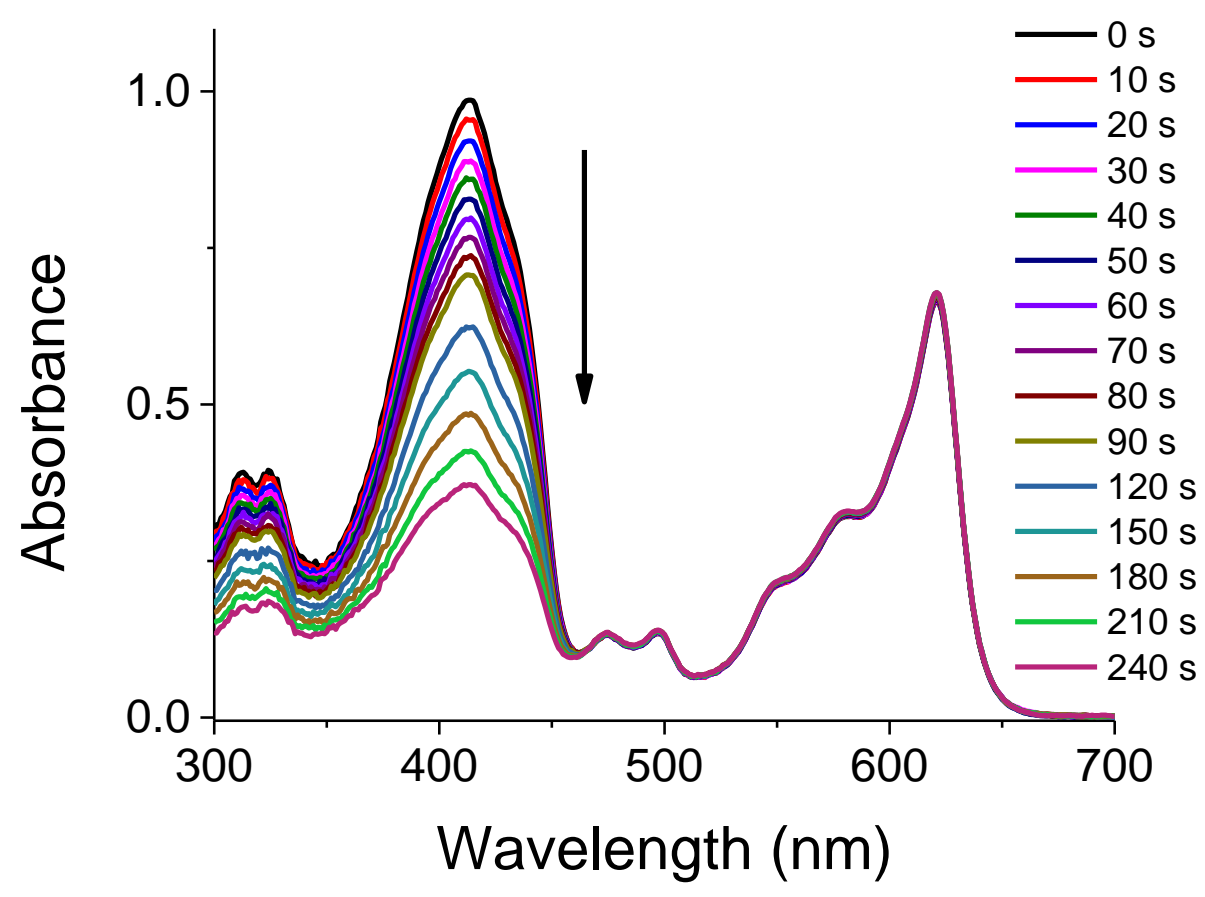

Figure S16: Absorption spectra of DPBF upon irradiation at $532 \mathrm{~nm}$ in the presence of BODIPY B2 in air saturated THF.

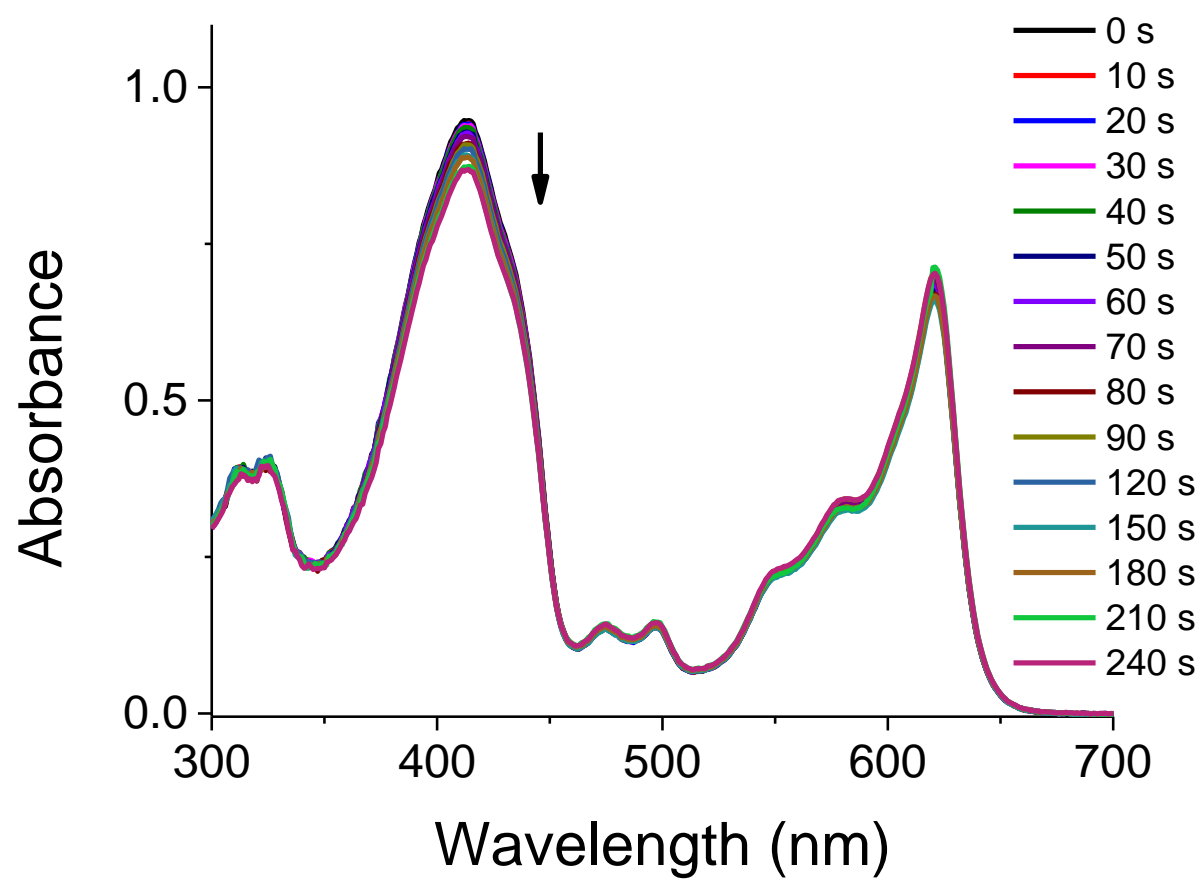

Figure S17: Absorption spectra of DPBF upon irradiation at $532 \mathrm{~nm}$ in the presence of BODIPY B2 in THF under argon atmosphere. 


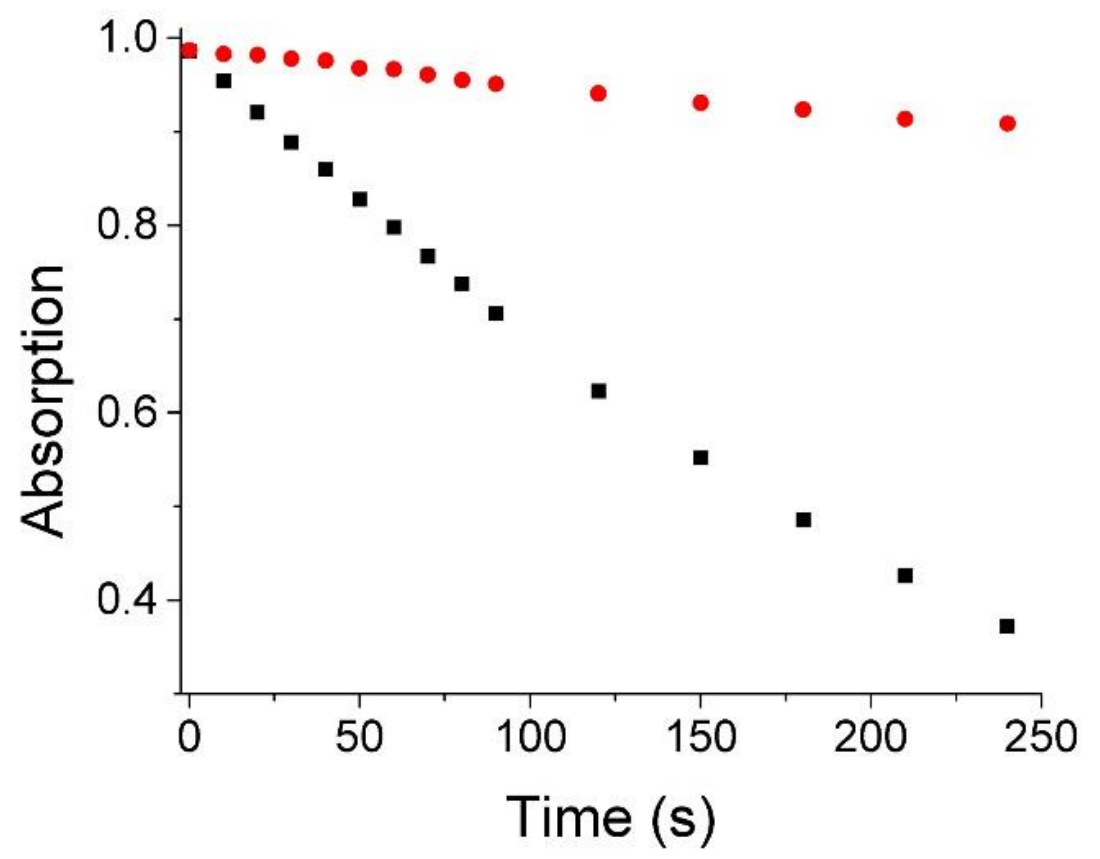

Figure S18: Comparative DPBF degradation profiles (absorbance at $415 \mathrm{~nm}$ ) by $\mathbf{B 2}$ under air (black dots) and argon atmosphere (red dots). 


\subsection{Reactive oxygen species trapping}

\section{a) Singlet oxygen specific trapping by ABDA}
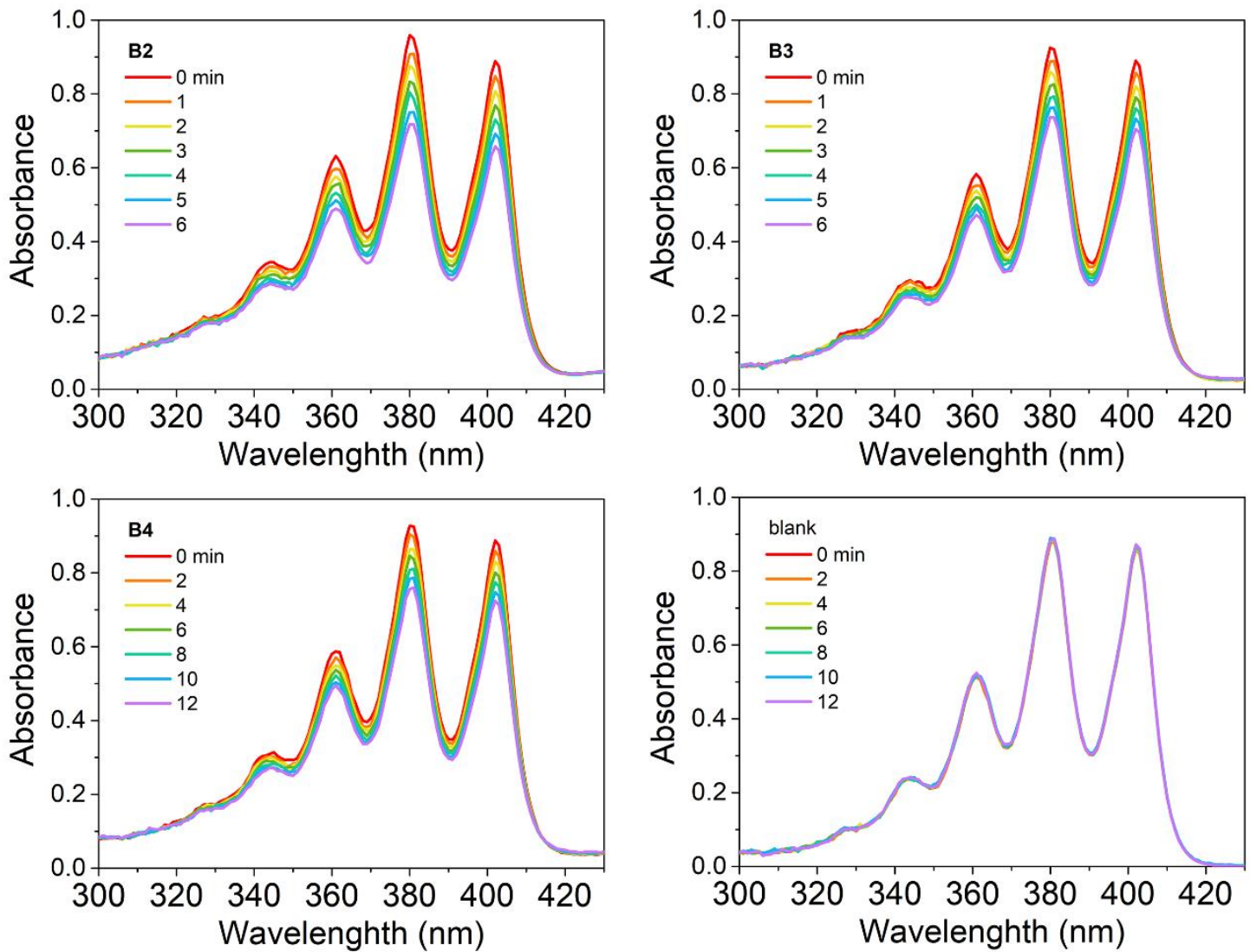

Figure S19. Photodegradatiuon curves of ABDA (2,2'-(Anthracene-9,10diyl)bis(methylene)dimalonic acid, a ${ }^{1} \mathrm{O}_{2}$ trap molecule) in the presence of photosensitizers B2-4 (absorbance at $532 \mathrm{~nm}=0.25$ ) in PBS/THF (v/v: 1/1) mixture under $532 \mathrm{~nm}$ light irradiation . 


\section{b) Reactive oxygen species trapping by EPR}
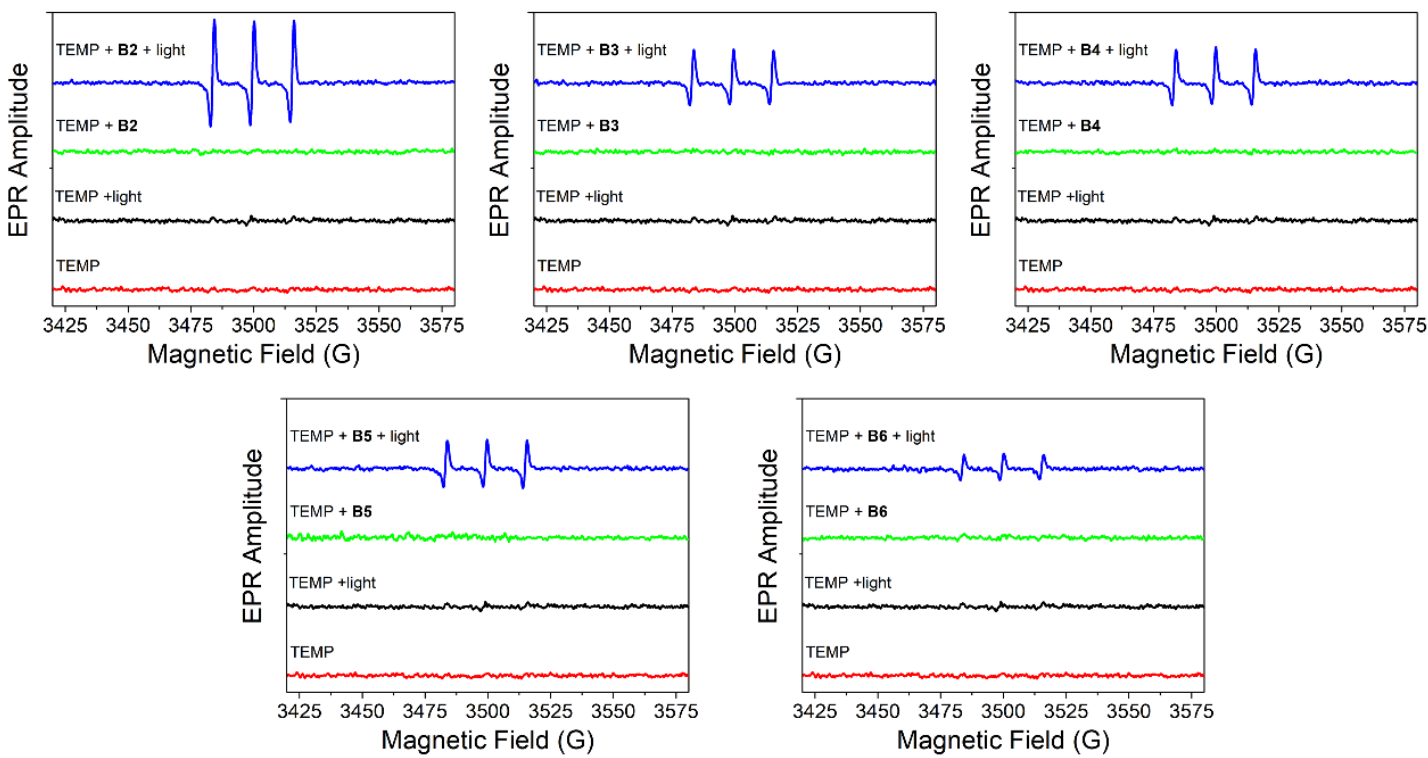

Figure S20. EPR spectra of B2, B3, B4 and B5 (0.3 mM in dichloromethane) for ${ }^{1} \mathrm{O}_{2}$ characterization with 2,2,6,6-tetramethyl-4-piperidone (TEMP, $50 \mathrm{mM}$ ) as the spin-trap reagent in different conditions.
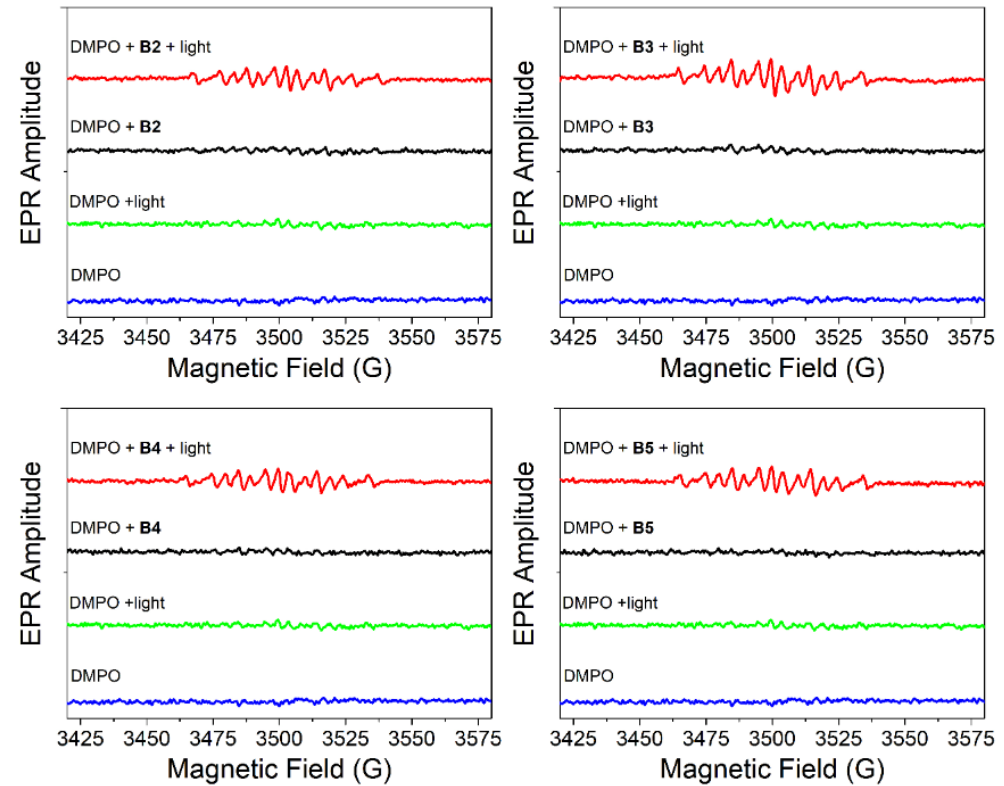

Figure 21. EPR spectra of B2, B3, B4 and B5 $(0.3 \mathrm{mM}$, in dichloromethane $)$ for $\mathrm{O}_{2}{ }^{-}$ characterization with 5,5-dimethyl-1-pyrroline-N-oxide (DMPO, $1 \mathrm{M}$ ) as the spin-trap reagent in different conditions. 


\section{Electrochemical Data}

Table S5. Electrochemical data acquired at $100 \mathrm{mV} / \mathrm{s}$, and HOMO-LUMO Gaps determined from spectroscopy of dyes B1-B6.

\begin{tabular}{|c|c|c|c|c|c|c|c|c|c|}
\hline dyes & $E_{1 / 2}^{\text {red }}(\mathrm{V})$ & $E_{1 / 2}{ }^{\mathrm{ox}}(\mathrm{V})$ & $\begin{array}{l}E_{\mathrm{pa}} \\
(\mathrm{V})\end{array}$ & $\begin{array}{c}E_{\text {red }}{ }^{\text {onset }} \\
(\mathrm{V})\end{array}$ & $\begin{array}{c}E_{\text {ox }}{ }^{\text {onset }} \\
(\mathrm{V}) \\
\end{array}$ & $\begin{array}{c}\text { LUMO } \\
(\mathrm{eV})\end{array}$ & $\begin{array}{c}\text { HOMO } \\
(\mathrm{eV})\end{array}$ & $\begin{array}{c}E_{\mathrm{g}}^{\mathrm{e}} \\
(\mathrm{eV})\end{array}$ & $\begin{array}{c}E_{\mathrm{g}}^{\mathrm{e}} \\
(\mathrm{eV})\end{array}$ \\
\hline B1 & -1.43 & - & 1.71 & -0.87 & 1.44 & -3.53 & -5.84 & 2.31 & 2.38 \\
\hline B2 & $-0.74,-1.18$ & - & 1.39 & -0.62 & 1.22 & -3.78 & -5.63 & 1.85 & 1.91 \\
\hline B3 & $\begin{array}{c}-0.59,-1.04 \\
-1.30\end{array}$ & 1.13 & - & -0.52 & 1.04 & -3.88 & -5.46 & 1.58 & 1.69 \\
\hline B4 & $\begin{array}{l}-0.54,-0.87 \\
-1.14,-1.33\end{array}$ & 1.11 & - & -0.47 & 1.03 & -3.92 & -5.44 & 1.52 & 1.58 \\
\hline \multirow[t]{2}{*}{ B5 } & $\begin{array}{c}-0.52,-0.73 \\
-1.02,-1.23 \\
-1.35\end{array}$ & $\begin{array}{l}1.34 \\
1.07\end{array}$ & - & -0.45 & 1.02 & -3.95 & -5.42 & 1.47 & 1.53 \\
\hline & $-0.51,-0.70$ & 1.52 & & & & & & & \\
\hline \multirow[t]{2}{*}{ B6 } & $-0.91,-1.12$ & 1.28 & - & -0.43 & 1.01 & -3.97 & -5.41 & 1.44 & 1.50 \\
\hline & -1.32 & 1.05 & & & & & & & \\
\hline \multicolumn{10}{|c|}{$\begin{array}{l}E_{1 / 2}{ }^{\text {red }}=\text { half wave potentials of reversible reduction potential; } E_{1 / 2}{ }^{\mathrm{ox}}=\text { half wave potentials of } \\
\text { reversible oxidation potential; } E_{\mathrm{pa}}=\text { irreversible oxidation peak potentials; } E_{\mathrm{red}}{ }^{\text {onset }}=\text { the onset } \\
\text { reduction potentials; } E_{\mathrm{ox}}{ }^{\text {onset }}=\text { the onset oxidation potentials; } E_{\mathrm{LUMO}}=-\mathrm{e}\left(E_{\mathrm{red}}{ }^{\text {onset }}+4.4\right) ; E_{\mathrm{HOMO}}= \\
-\mathrm{e}\left(E_{\mathrm{ox}}{ }^{\text {onset }}+4.4\right) ; E_{\mathrm{g}}{ }^{\mathrm{e}}=\text { bandgap, obtained from the intercept of the electrochemical data; } E_{\mathrm{g}}{ }^{\mathrm{e}}= \\
E_{\mathrm{LUMO}}-E_{\mathrm{HOMO}} ; E_{\mathrm{g}}{ }^{\mathrm{o}}=\text { bandgap, obtained from the intercept of the absorption spectra. }\end{array}$} \\
\hline
\end{tabular}




\section{DFT Calculations}

The ground state geometry was optimized by using DFT method at B3LYP/6-31G(d) level. The same method was used for vibrational analysis to verify that the optimized structures correspond to local minima on the energy surface. TD-DFT computations were used the optimized ground state geometries under the B3LYP/6-31G(d,p) theoretical level. The calculated molecules in dichloromethane were done using the Self-Consistent Reaction Field (SCRF) method and Polarizable Continuum Model (PCM). The geometries of the lowest singlet (S1) excited states were also optimized at the TD-B3LYP/6-31G(d) level of theory. All of the calculations were carried out by the methods implemented in Gaussian 09 package. ${ }^{9 a}$ SOCs were computed using the quadraticresponse TDDFT approach, ${ }^{9 b}$ i.e. QR-TD-DFT, as implemented in the Dalton program ${ }^{9 c}$ at their T1 optimized geometries. The SOC operator makes use of a semi-empirical effective single-electron approximation. ${ }^{9 \mathrm{~d}}$ For the latter calculations the B3LYP functional in combination to the $6-31 \mathrm{G}(\mathrm{d})$ basis set was used. 
Table S6. Selected electronic excitation energies (eV) and oscillator strengths (f), configurations of the low-lying singlet excited states of oligomers B2-B4 calculated by TDDFT//B3LYP/6-31G(d,p), based on the optimized ground state geometries.

\begin{tabular}{|c|c|c|c|c|c|}
\hline & \multirow{2}{*}{$\begin{array}{l}\text { Electronic } \\
\text { transition }\end{array}$} & \multicolumn{4}{|c|}{ TD//B3LYP/6-31G(d, p) } \\
\hline & & Energy/ eV ${ }^{[a]}$ & $f^{[\mathrm{b}]}$ & Composition $^{[\mathrm{c}]}$ & $\mathrm{CI}^{[\mathrm{d}]}$ \\
\hline \multirow[t]{8}{*}{ B2 } & $\mathrm{S} 0 \rightarrow \mathrm{S} 1$ & $2.2461 \mathrm{eV} 552.01 \mathrm{~nm}$ & 1.0219 & $\mathrm{HOMO} \rightarrow$ LUMO & 0.7070 \\
\hline & $\mathrm{S} 0 \rightarrow \mathrm{S} 3$ & $3.0528 \mathrm{eV} 406.14 \mathrm{~nm}$ & 0.1882 & HOMO - $1 \rightarrow$ LUMO & 0.5817 \\
\hline & & & & $\mathrm{HOMO} \rightarrow \mathrm{LUMO}+1$ & 0.3553 \\
\hline & $\mathrm{S} 0 \rightarrow \mathrm{S} 4$ & $3.1466 \mathrm{eV} 394.03 \mathrm{~nm}$ & 0.2759 & HOMO -2 $\rightarrow$ LUMO & 0.1281 \\
\hline & & & & $\mathrm{HOMO}-1 \rightarrow \mathrm{LUMO}+1$ & 0.6845 \\
\hline & $\mathrm{S} 0 \rightarrow \mathrm{S} 5$ & $3.4940 \mathrm{eV} 354.85 \mathrm{~nm}$ & 0.1518 & HOMO $-3 \rightarrow$ LUMO +1 & 0.2079 \\
\hline & & & & HOMO -2 $\rightarrow$ LUMO & 0.6553 \\
\hline & & & & HOMO - $1 \rightarrow$ LUMO + 1 & 0.1456 \\
\hline \multirow[t]{9}{*}{ B3 } & $\mathrm{S} 0 \rightarrow \mathrm{S} 1$ & $1.9547 \mathrm{eV} 634.30 \mathrm{~nm}$ & 1.1363 & HOMO $\rightarrow$ LUMO & 0.7048 \\
\hline & $\mathrm{S} 0 \rightarrow \mathrm{S} 3$ & $2.4460 \mathrm{eV} 506.89 \mathrm{~nm}$ & 0.5306 & HOMO -1 $\rightarrow$ LUMO & 0.5496 \\
\hline & & & & $\mathrm{HOMO}-1 \rightarrow \mathrm{LUMO}+2$ & 0.1314 \\
\hline & & & & $\mathrm{HOMO} \rightarrow \mathrm{LUMO}+1$ & 0.4185 \\
\hline & $\mathrm{S} 0 \rightarrow \mathrm{S} 5$ & $2.7136 \mathrm{eV} 456.90 \mathrm{~nm}$ & 0.2734 & HOMO -2 $\rightarrow$ LUMO & 0.3637 \\
\hline & & & & $\mathrm{HOMO}-1 \rightarrow \mathrm{LUMO}+1$ & 0.5988 \\
\hline & $\mathrm{S} 0 \rightarrow \mathrm{S} 6$ & $2.9152 \mathrm{eV} 425.30 \mathrm{~nm}$ & 0.1236 & $\mathrm{HOMO}-2 \rightarrow \mathrm{LUMO}+1$ & 0.1227 \\
\hline & & & & HOMO -1 $\rightarrow$ LUMO & 0.1305 \\
\hline & & & & $\mathrm{HOMO}-1 \rightarrow \mathrm{LUMO}+2$ & 0.6783 \\
\hline \multirow[t]{5}{*}{ B4 } & $\mathrm{S} 0 \rightarrow \mathrm{S} 1$ & $1.8142 \mathrm{eV} \quad 683.40 \mathrm{~nm}$ & 1.1695 & HOMO $\rightarrow$ LUMO & 0.6997 \\
\hline & $\mathrm{S} 0 \rightarrow \mathrm{S} 3$ & $2.2029 \mathrm{eV} 562.82 \mathrm{~nm}$ & 0.8098 & HOMO -1 $\rightarrow$ LUMO & 0.5735 \\
\hline & & & & $\mathrm{HOMO} \rightarrow \mathrm{LUMO}+1$ & 0.4035 \\
\hline & $\mathrm{S} 0 \rightarrow \mathrm{S} 5$ & $2.4044 \mathrm{eV} 515.66 \mathrm{~nm}$ & 0.2736 & HOMO -2 $\rightarrow$ LUMO & 0.1787 \\
\hline & & & & HOMO - $1 \rightarrow$ LUMO +1 & 0.6651 \\
\hline
\end{tabular}

[a] Only the selected low-lying excited states are presented. [b] Oscillator strength. [c] Only the main configurations are presented. [d] The CI coefficients are in absolute values. 
Table S7. Selected electronic excitation energies (eV) and oscillator strengths (f), configurations of the low-lying triplet excited states of oligomers B2-B4 calculated by TDDFT//B3LYP/6-31G(d,p), based on the optimized ground state geometries.

\begin{tabular}{|c|c|c|c|c|c|}
\hline & \multirow{2}{*}{$\begin{array}{l}\text { Electronic } \\
\text { transition }\end{array}$} & \multicolumn{4}{|c|}{ TD//B3LYP/6-31G(d, p) } \\
\hline & & Energy/ eV ${ }^{[a]}$ & $f^{[\mathrm{b}]}$ & Composition $^{[\mathrm{c}]}$ & $\mathbf{C I}^{[\mathrm{d}]}$ \\
\hline \multirow[t]{7}{*}{ B2 } & $\mathrm{S} 0 \rightarrow \mathrm{T} 1$ & $1.3744 \mathrm{eV} 902.12 \mathrm{~nm}$ & 0.0000 & $\mathrm{HOMO}-1 \rightarrow \mathrm{LUMO}+1$ & 0.2755 \\
\hline & & & & HOMO $\rightarrow$ LUMO & 0.6546 \\
\hline & $\mathrm{S} 0 \rightarrow \mathrm{T} 2$ & $1.5498 \mathrm{eV} 799.98 \mathrm{~nm}$ & 0.0000 & HOMO - $1 \rightarrow$ LUMO & 0.4252 \\
\hline & & & & $\mathrm{HOMO} \rightarrow \mathrm{LUMO}+1$ & 0.5665 \\
\hline & $\mathrm{S} 0 \rightarrow \mathrm{T} 3$ & $2.4399 \mathrm{eV} 508.16 \mathrm{~nm}$ & 0.0000 & HOMO -6 $\rightarrow$ LUMO & 0.1522 \\
\hline & & & & HOMO - $1 \rightarrow$ LUMO & 0.5442 \\
\hline & & & & HOMO $\rightarrow$ LUMO +1 & 0.4165 \\
\hline \multirow[t]{8}{*}{ B3 } & $\mathrm{S} 0 \rightarrow \mathrm{T} 1$ & $1.2794 \mathrm{eV} 969.11 \mathrm{~nm}$ & 0.0000 & $\mathrm{HOMO}-1 \rightarrow \mathrm{LUMO}+1$ & 0.1985 \\
\hline & & & & HOMO $\rightarrow$ LUMO & 0.6420 \\
\hline & $\mathrm{S} 0 \rightarrow \mathrm{T} 2$ & $1.4532 \mathrm{eV} 853.21 \mathrm{~nm}$ & 0.0000 & $\mathrm{HOMO} \rightarrow \mathrm{LUMO}+1$ & 0.4743 \\
\hline & & & & HOMO -1 $\rightarrow$ LUMO & 0.3916 \\
\hline & & & & $\mathrm{HOMO}-1 \rightarrow \mathrm{LUMO}+1$ & 0.2752 \\
\hline & $\mathrm{S} 0 \rightarrow \mathrm{T} 3$ & $1.5394 \mathrm{eV} 805.42 \mathrm{~nm}$ & 0.0000 & $\mathrm{HOMO} \rightarrow \mathrm{LUMO}+2$ & 0.3637 \\
\hline & & & & $\mathrm{HOMO}-1 \rightarrow \mathrm{LUMO}+1$ & 0.4031 \\
\hline & & & & HOMO -2 $\rightarrow$ LUMO & 0.3281 \\
\hline \multirow[t]{13}{*}{ B4 } & $\mathrm{S} 0 \rightarrow \mathrm{T} 1$ & $1.2384 \mathrm{eV} 1001.17 \mathrm{~nm}$ & 0.0000 & HOMO $\rightarrow$ LUMO & 0.6177 \\
\hline & & & & $\mathrm{HOMO}-1 \rightarrow \mathrm{LUMO}+1$ & 0.2349 \\
\hline & & & & HOMO $-2 \rightarrow$ LUMO +2 & 0.1334 \\
\hline & & & & $\mathrm{HOMO}-3 \rightarrow \mathrm{LUMO}+3$ & 0.1505 \\
\hline & $\mathrm{S} 0 \rightarrow \mathrm{T} 2$ & $1.3582 \mathrm{eV} 912.83 \mathrm{~nm}$ & 0.0000 & HOMO -1 $\rightarrow$ LUMO & 0.4177 \\
\hline & & & & $\mathrm{HOMO} \rightarrow \mathrm{LUMO}+1$ & 0.4660 \\
\hline & & & & $\mathrm{HOMO}-2 \rightarrow \mathrm{LUMO}+3$ & 0.1724 \\
\hline & & & & $\mathrm{HOMO}-3 \rightarrow \mathrm{LUMO}+2$ & 0.1562 \\
\hline & & & & $\mathrm{HOMO} \rightarrow \mathrm{LUMO}+3$ & 0.1385 \\
\hline & $\mathrm{S} 0 \rightarrow \mathrm{T} 3$ & $1.4866 \mathrm{eV} 834.04 \mathrm{~nm}$ & 0.0000 & $\mathrm{HOMO} \rightarrow \mathrm{LUMO}+2$ & 0.3865 \\
\hline & & & & HOMO $-1 \rightarrow$ LUMO +1 & 0.3334 \\
\hline & & & & HOMO -2 $\rightarrow$ LUMO & 0.2856 \\
\hline & & & & HOMO $-1 \rightarrow$ LUMO +3 & 0.2607 \\
\hline
\end{tabular}

[a] Only the selected low-lying excited states are presented. [b] Oscillator strength. [c] Only the main configurations are presented. [d] The CI coefficients are in absolute values. 
Table S8. Lowest vertical singlet and triplet electronic transition energies (in eV) and oscillator strengths (in parentheses) of B2-B4 at the TD-B3LYP levels, along with vertical singlet-triplet splittings (in eV) and SOCs between the involved $\mathrm{T}_{\mathrm{m}}$ and $\mathrm{S}_{1}$ states (in $\mathrm{cm}^{-1}$ ).

\begin{tabular}{|c|c|c|c|c|}
\hline Oligomers & State/Assignment $^{\mathrm{a}}$ & TD-B3LYP & $\Delta \mathrm{E}_{\mathrm{S} 1-\mathrm{T} 1}$ & $\left\langle\mathrm{~S}_{1}\left|\hat{\mathrm{H}}_{\mathrm{SO}}\right| \mathrm{T}_{\mathrm{m}}\right\rangle^{\mathrm{b}}$ \\
\hline \multirow{3}{*}{ B2 } & $\mathrm{S}_{1}(\mathrm{H} \rightarrow \mathrm{L}, \mathrm{c}=0.71)$ & $2.25(1.02)$ & - & - \\
\hline & $\mathrm{T}_{1}(\mathrm{H} \rightarrow \mathrm{L}, \mathrm{c}=0.65 ; \mathrm{H}-1 \rightarrow \mathrm{L}+1, \mathrm{c}=0.28)$ & 1.37 & 0.88 & $(0.00 ;-3.03 ; 0.01)$ \\
\hline & $\mathrm{T}_{2}(\mathrm{H}-1 \rightarrow \mathrm{L}, \mathrm{c}=0.43 ; \mathrm{H} \rightarrow \mathrm{L}+1, \mathrm{c}=0.57)$ & 1.55 & 0.7 & $(1.79 ; 0.00 ; 4.81)$ \\
\hline \multirow{4}{*}{ B3 } & $\mathrm{S}_{1}(\mathrm{H} \rightarrow \mathrm{L}, \mathrm{c}=0.70)$ & $1.95(1.14)$ & - & - \\
\hline & $\mathrm{T}_{1}(\mathrm{H} \rightarrow \mathrm{L}, \mathrm{c}=0.64 ; \mathrm{H}-1 \rightarrow \mathrm{L}+1, \mathrm{c}=0.20)$ & 1.28 & 0.67 & $(-0.16 ; 0.71 ; 0.23)$ \\
\hline & $\mathrm{T}_{2}(\mathrm{H}-1 \rightarrow \mathrm{L}, \mathrm{c}=0.43 ; \mathrm{H} \rightarrow \mathrm{L}+1, \mathrm{c}=0.57)$ & 1.45 & 0.5 & $(-0.28 ; 0.04 ; 1.43)$ \\
\hline & $\begin{aligned} \mathrm{T}_{3}(\mathrm{H} \rightarrow \mathrm{L}+2, \mathrm{c} & =0.36 ; \mathrm{H}-1 \rightarrow \mathrm{L}, \mathrm{c}=0.40 ; \mathrm{H}-2 \\
& \rightarrow \mathrm{L}+, \mathrm{c}=0.33)\end{aligned}$ & 1.53 & 0.52 & $(-0.01 ; 2.35 ; 0.02)$ \\
\hline \multirow{4}{*}{ B4 } & $\mathrm{S}_{1}(\mathrm{H} \rightarrow \mathrm{L}, \mathrm{c}=0.70)$ & $1.81(1.17)$ & - & - \\
\hline & $\begin{array}{c}\mathrm{T}_{1}(\mathrm{H} \rightarrow \mathrm{L}, \mathrm{c}=0.62 ; \mathrm{H}-1 \rightarrow \mathrm{L}+1, \mathrm{c}=0.23 ; \mathrm{H}-2 \\
\quad \rightarrow \mathrm{L}+2, \mathrm{c}=0.13 ; \mathrm{H}-3 \rightarrow \mathrm{L}+3, \mathrm{c}=0.15)\end{array}$ & 1.24 & 0.57 & $(0.00 ;-0.81 ; 0.00)$ \\
\hline & $\begin{array}{c}\mathrm{T}_{2}(\mathrm{H}-1 \rightarrow \mathrm{L}, \mathrm{c}=0.42 ; \mathrm{H} \rightarrow \mathrm{L}+1, \mathrm{c}=0.47 ; \mathrm{H}-2 \\
\rightarrow \mathrm{L}+3, \mathrm{c}=0.17 ; \mathrm{H}-3 \rightarrow \mathrm{L}+2, \mathrm{c}=0.16 ; \mathrm{H} \rightarrow \mathrm{L} \\
+3, \mathrm{c}=0.14)\end{array}$ & 1.36 & 0.45 & $(-0.41 ; 0.00 ;-1.11)$ \\
\hline & $\begin{array}{c}\mathrm{T}_{3}(\mathrm{H} \rightarrow \mathrm{L}+2, \mathrm{c}=0.39 ; \mathrm{H}-1 \rightarrow \mathrm{L}+1, \mathrm{c}=0.33 ; \mathrm{H} \\
-2 \rightarrow \mathrm{L}, \mathrm{c}=0.29 ; \mathrm{H}-1 \rightarrow \mathrm{L}+3, \mathrm{c}=0.26)\end{array}$ & 1.49 & 0.32 & $(-1.05 ; 0.00 ;-0.31)$ \\
\hline
\end{tabular}

${ }^{\mathrm{a}}$ Only the excited states which are below the first excited states are considered; ${ }^{\mathrm{b}}$ Values are shown as $(\mathrm{x}$ component; y component; z component) and were obtained at the QR-TD-DFT/6-31G* level of theory at the S1 optimized geometry. 


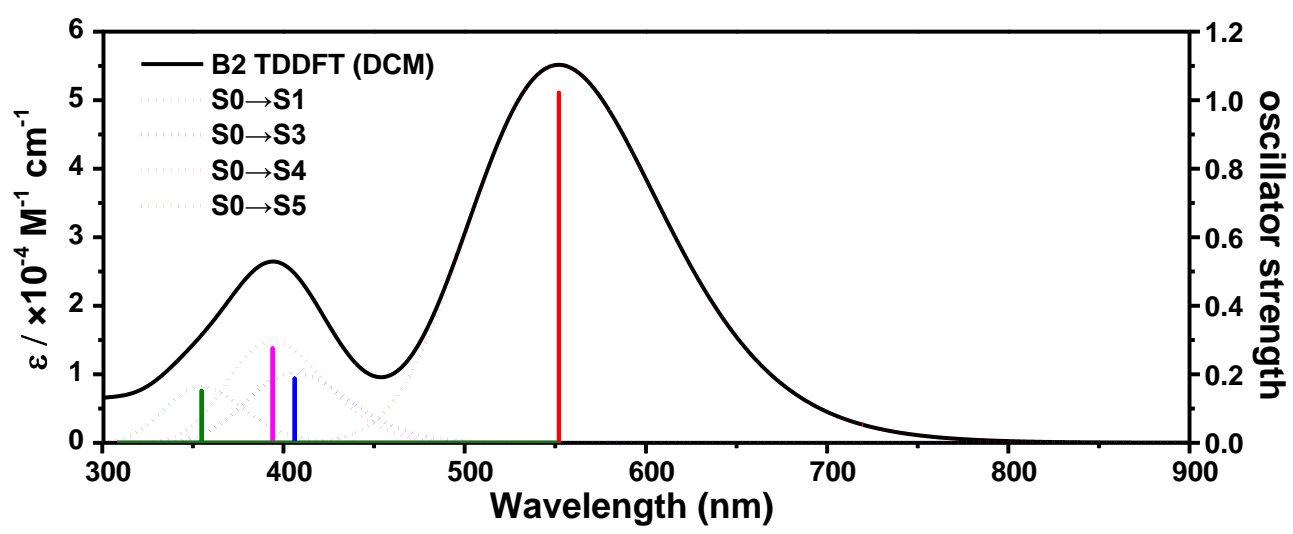

Figure S22: Calculated UV-vis absorption of energy-minimized calculated B2.

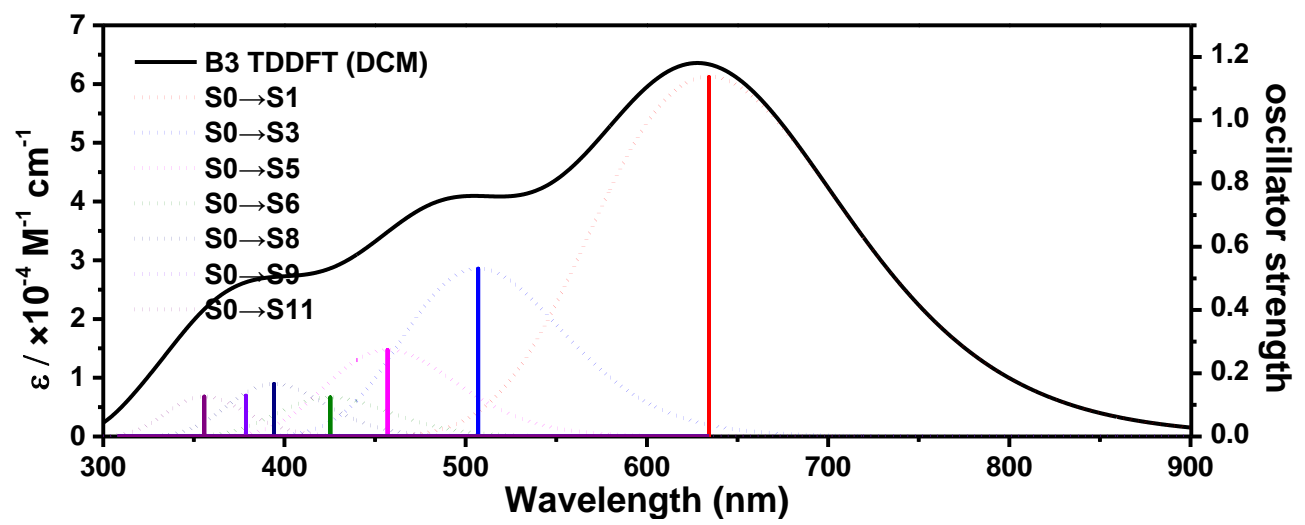

Figure S23: Calculated UV-vis absorption of energy-minimized calculated B3.

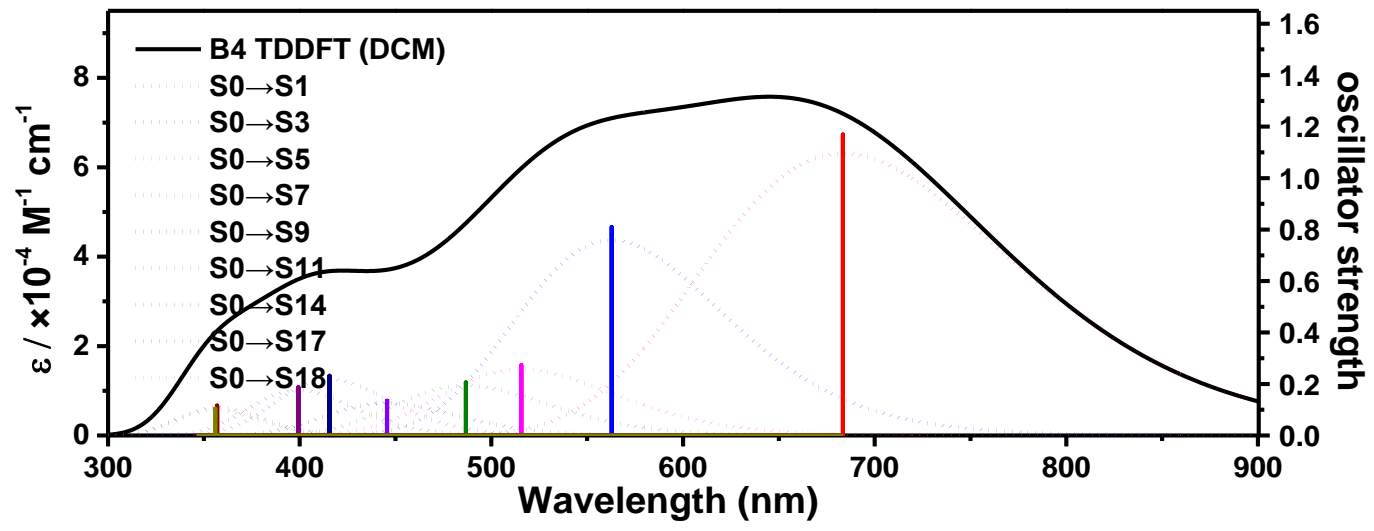

Figure S24: Calculated UV-vis absorption of energy-minimized calculated B4. 
Optimized Geometries of the Compounds.

B2, optimized $\mathrm{S}_{0}$ state Geometry.

\begin{tabular}{|c|c|c|c|}
\hline$S$ & 0.00000400 & -0.36616400 & 0.00001200 \\
\hline $\mathrm{F}$ & 2.58320900 & -1.98573800 & 0.05232300 \\
\hline $\mathrm{F}$ & -2.90650000 & -0.66991600 & -1.89689200 \\
\hline $\mathrm{F}$ & -2.58327700 & -1.98576500 & -0.05189900 \\
\hline $\mathrm{F}$ & 2.90665400 & -0.66950600 & 1.89701000 \\
\hline $\mathrm{N}$ & 2.58124600 & 0.42052100 & -0.24675700 \\
\hline $\mathrm{N}$ & -2.58125300 & 0.42054000 & 0.24670300 \\
\hline $\mathrm{N}$ & 4.69286000 & -0.81528500 & 0.27273200 \\
\hline $\mathrm{N}$ & -4.69287500 & -0.81527000 & -0.27278000 \\
\hline $\mathrm{C}$ & -3.36254300 & 1.43943900 & 0.79723200 \\
\hline $\mathrm{C}$ & -1.19846600 & 1.99763700 & 1.12224600 \\
\hline $\mathrm{H}$ & -0.28208600 & 2.48325500 & 1.42364400 \\
\hline $\mathrm{C}$ & -1.28703600 & 0.75451300 & 0.44409100 \\
\hline $\mathrm{C}$ & 5.41501700 & 0.23640400 & -0.29373500 \\
\hline $\mathrm{C}$ & 3.36254100 & 1.43942600 & -0.79727800 \\
\hline $\mathrm{C}$ & -4.75171000 & 1.34859200 & 0.80453300 \\
\hline $\mathrm{C}$ & 4.75170500 & 1.34857800 & -0.80457300 \\
\hline $\mathrm{C}$ & -2.49758700 & 2.42715900 & 1.33176700 \\
\hline $\mathrm{H}$ & -2.81802100 & 3.32995100 & 1.83485400 \\
\hline $\mathrm{C}$ & -5.41502300 & 0.23642100 & 0.29369700 \\
\hline $\mathrm{C}$ & 6.79127600 & -0.10529100 & -0.26383200 \\
\hline $\mathrm{H}$ & 7.59499500 & 0.51234900 & -0.64233500 \\
\hline $\mathrm{C}$ & 2.49758200 & 2.42715200 & -1.33179800 \\
\hline $\mathrm{H}$ & 2.81801200 & 3.32994800 & -1.83488200 \\
\hline $\mathrm{C}$ & -6.79129300 & -0.10522600 & 0.26371700 \\
\hline $\mathrm{H}$ & -7.59500800 & 0.51243200 & 0.64220200 \\
\hline $\mathrm{C}$ & 1.19846200 & 1.99761400 & -1.12230900 \\
\hline $\mathrm{H}$ & 0.28208400 & 2.48321700 & -1.42373800 \\
\hline $\mathrm{C}$ & 1.28703200 & 0.75449800 & -0.44413500 \\
\hline $\mathrm{C}$ & -5.57213300 & -1.76554900 & -0.63559200 \\
\hline $\mathrm{C}$ & 5.57210000 & -1.76561800 & 0.63545300 \\
\hline $\mathrm{C}$ & -6.88603500 & -1.36405900 & -0.31787700 \\
\hline $\mathrm{C}$ & 6.88599800 & -1.36416200 & 0.31768900 \\
\hline B & -3.15603700 & -0.81584700 & -0.53783800 \\
\hline B & 3.15605700 & -0.81573900 & 0.53795900 \\
\hline $\mathrm{H}$ & 7.78145000 & -1.94319700 & 0.49598900 \\
\hline $\mathrm{H}$ & 5.23604900 & -2.68177500 & 1.10276600 \\
\hline $\mathrm{H}$ & -5.23609900 & -2.68169600 & -1.10293800 \\
\hline $\mathrm{H}$ & -7.78149900 & -1.94304900 & -0.49626300 \\
\hline $\mathrm{H}$ & 5.32825900 & 2.15735500 & -1.24152500 \\
\hline $\mathrm{H}$ & -5.32826100 & 2.15736500 & 1.24149300 \\
\hline
\end{tabular}

SCF done: -1759.75756458 Hartree

No imaginary Frequency.

B3, optimized $\mathrm{S}_{0}$ state Geometry.

$\begin{array}{cccc}\text { S } & 2.99905300 & 0.38703000 & 0.27067700 \\ \mathrm{~F} & -0.00215000 & 0.68558300 & 1.07846700 \\ \mathrm{~F} & 5.84016800 & -0.64691300 & 2.03517600 \\ \mathrm{~F} & 4.41561900 & -2.17387900 & 1.09839400 \\ \mathrm{~F} & -0.00311400 & 0.77572700 & -1.21080800 \\ \mathrm{~N} & 1.25591600 & 2.45346900 & 0.02783600 \\ \mathrm{~N} & 5.46537700 & -0.54353700 & -0.35891800 \\ \mathrm{~N} & -1.25659800 & 2.45990600 & -0.02563500 \\ & & & \mathrm{~S} 36\end{array}$




\begin{tabular}{|c|c|c|c|}
\hline$N$ & 6.78841200 & -2.40094800 & 0.66495300 \\
\hline $\mathrm{C}$ & 6.45220800 & -0.43733200 & -1.34242800 \\
\hline $\mathrm{C}$ & 4.81168700 & 1.02230900 & -1.87118700 \\
\hline $\mathrm{H}$ & 4.18954200 & 1.75796800 & -2.35905800 \\
\hline $\mathrm{C}$ & 4.48380700 & 0.32784000 & -0.67810300 \\
\hline $\mathrm{C}$ & -1.21253100 & 3.85447900 & 0.00854000 \\
\hline $\mathrm{C}$ & 1.21919700 & 3.84869200 & 0.03941100 \\
\hline $\mathrm{C}$ & 7.57041700 & -1.26620100 & -1.32224000 \\
\hline $\mathrm{C}$ & 0.00509500 & 4.52809000 & 0.03385800 \\
\hline $\mathrm{C}$ & 6.04692500 & 0.54807000 & -2.27753500 \\
\hline $\mathrm{H}$ & 6.60375600 & 0.83785200 & -3.15882400 \\
\hline $\mathrm{C}$ & 7.73678700 & -2.24652900 & -0.34761600 \\
\hline $\mathrm{C}$ & -2.54176900 & 4.34620600 & -0.01439100 \\
\hline $\mathrm{H}$ & -2.81943900 & 5.39187600 & -0.00087500 \\
\hline $\mathrm{C}$ & 2.55096900 & 4.33190700 & 0.09185200 \\
\hline $\mathrm{H}$ & 2.83434300 & 5.37582900 & 0.11753700 \\
\hline $\mathrm{C}$ & 8.73004100 & -3.24482300 & -0.17910200 \\
\hline $\mathrm{H}$ & 9.59048500 & -3.38191500 & -0.82062700 \\
\hline $\mathrm{C}$ & 3.38904300 & 3.23102300 & 0.13276000 \\
\hline $\mathrm{H}$ & 4.46695400 & 3.21880000 & 0.20048900 \\
\hline $\mathrm{C}$ & 2.55560700 & 2.08419400 & 0.09439900 \\
\hline $\mathrm{C}$ & 7.16785100 & -3.44314100 & 1.42483200 \\
\hline $\mathrm{C}$ & -2.55929800 & 2.09996000 & -0.09074700 \\
\hline $\mathrm{C}$ & 8.36816300 & -3.99610800 & 0.93306600 \\
\hline $\mathrm{C}$ & -3.38643900 & 3.25146500 & -0.08250100 \\
\hline B & 5.58555700 & -1.44364900 & 0.92523700 \\
\hline B & -0.00181100 & 1.51624300 & -0.03519700 \\
\hline $\mathrm{H}$ & -4.46515000 & 3.24679300 & -0.13787900 \\
\hline $\mathrm{H}$ & 6.57850800 & -3.74934100 & 2.27899700 \\
\hline $\mathrm{H}$ & 8.88752200 & -4.84666500 & 1.35225600 \\
\hline S & -3.01613500 & 0.41213800 & -0.31782600 \\
\hline $\mathrm{F}$ & -4.44269400 & -2.13246300 & -1.16566200 \\
\hline B & -5.61210100 & -1.41535700 & -0.94110800 \\
\hline $\mathrm{F}$ & -5.90495900 & -0.59540500 & -2.02446100 \\
\hline $\mathrm{N}$ & -6.80027100 & -2.38690300 & -0.66743400 \\
\hline $\mathrm{N}$ & -5.45942600 & -0.54433100 & 0.35935500 \\
\hline $\mathrm{C}$ & -7.72190500 & -2.25895800 & 0.37308000 \\
\hline $\mathrm{C}$ & -7.19419900 & -3.41576000 & -1.43824800 \\
\hline $\mathrm{C}$ & -6.41979700 & -0.46428400 & 1.37130200 \\
\hline $\mathrm{C}$ & -4.47221800 & 0.32298500 & 0.67181000 \\
\hline $\mathrm{C}$ & -7.53419600 & -1.29810700 & 1.36340800 \\
\hline $\mathrm{C}$ & -8.71358500 & -3.25966900 & 0.21089600 \\
\hline $\mathrm{C}$ & -8.37751500 & -3.98601600 & -0.92585400 \\
\hline $\mathrm{C}$ & -5.99229300 & 0.50111300 & 2.31740200 \\
\hline $\mathrm{C}$ & -4.76996300 & 0.98893300 & 1.88904700 \\
\hline $\mathrm{H}$ & -9.55545900 & -3.41537000 & 0.87251600 \\
\hline $\mathrm{H}$ & -8.90312700 & -4.83119900 & -1.34812600 \\
\hline $\mathrm{H}$ & -6.52596000 & 0.76870200 & 3.21978900 \\
\hline $\mathrm{H}$ & -4.13731800 & 1.71563800 & 2.37675400 \\
\hline $\mathrm{H}$ & -6.62631000 & -3.70076500 & -2.31401000 \\
\hline $\mathrm{H}$ & 8.31734400 & -1.16046500 & -2.10249700 \\
\hline $\mathrm{H}$ & 0.00732000 & 5.61286000 & 0.05235100 \\
\hline $\mathrm{H}$ & -8.26017100 & -1.21294100 & 2.16562400 \\
\hline
\end{tabular}

SCF done: -2838.12939770 Hartree

No imaginary Frequency.

B4, optimized $\mathrm{S}_{0}$ state Geometry. 


\begin{tabular}{|c|c|c|c|}
\hline S & -0.00035800 & -2.34655800 & 0.00071600 \\
\hline $\mathrm{F}$ & -2.49442900 & -0.78027100 & -1.10882400 \\
\hline $\mathrm{F}$ & 3.26411200 & -1.97572100 & -0.68511800 \\
\hline $\mathrm{F}$ & 2.49414100 & -0.78057900 & 1.10969100 \\
\hline $\mathrm{F}$ & -3.26503600 & -1.97623100 & 0.68518600 \\
\hline $\mathrm{N}$ & -2.29233000 & -3.18206000 & -1.19500500 \\
\hline $\mathrm{N}$ & 2.29229900 & -3.18246200 & 1.19496300 \\
\hline $\mathrm{N}$ & -4.54259900 & -2.07763700 & -1.35659000 \\
\hline $\mathrm{N}$ & 4.54253500 & -2.07785000 & 1.35608100 \\
\hline $\mathrm{C}$ & 2.76908600 & -4.18571900 & 2.04031600 \\
\hline $\mathrm{C}$ & 0.61932700 & -4.67837000 & 1.55619200 \\
\hline $\mathrm{H}$ & -0.36124600 & -5.12886600 & 1.50816700 \\
\hline $\mathrm{C}$ & 1.00079300 & -3.47220500 & 0.91571200 \\
\hline $\mathrm{C}$ & -4.93853500 & -3.10215500 & -2.21786200 \\
\hline $\mathrm{C}$ & -2.76866100 & -4.18500200 & -2.04103600 \\
\hline $\mathrm{C}$ & 4.06556400 & -4.13569300 & 2.54299500 \\
\hline $\mathrm{C}$ & -4.06490500 & -4.13494800 & -2.54415500 \\
\hline $\mathrm{C}$ & 1.72831400 & -5.12395500 & 2.25458000 \\
\hline $\mathrm{H}$ & 1.80448800 & -6.00835900 & 2.87322600 \\
\hline $\mathrm{C}$ & 4.93887600 & -3.10265800 & 2.21687600 \\
\hline $\mathrm{C}$ & -6.28630000 & -2.87616800 & -2.59386800 \\
\hline $\mathrm{H}$ & -6.86407000 & -3.51110500 & -3.25239000 \\
\hline $\mathrm{C}$ & -1.72773400 & -5.12319300 & -2.25502200 \\
\hline $\mathrm{H}$ & -1.80356800 & -6.00735300 & -2.87405700 \\
\hline $\mathrm{C}$ & 6.28662200 & -2.87634100 & 2.59290200 \\
\hline $\mathrm{H}$ & 6.86465200 & -3.51144900 & 3.25103400 \\
\hline $\mathrm{C}$ & -0.61914500 & -4.67781200 & -1.55594400 \\
\hline $\mathrm{H}$ & 0.36144700 & -5.12822500 & -1.50756000 \\
\hline $\mathrm{C}$ & -1.00103300 & -3.47188100 & -0.91515400 \\
\hline $\mathrm{C}$ & 5.60789800 & -1.26182600 & 1.18429100 \\
\hline $\mathrm{C}$ & -5.60829600 & -1.26199800 & -1.18451900 \\
\hline $\mathrm{C}$ & 6.71025400 & -1.72919500 & 1.94407600 \\
\hline $\mathrm{C}$ & -6.71037800 & -1.72940900 & -1.94455300 \\
\hline B & 3.12377100 & -1.94822300 & 0.69720100 \\
\hline B & -3.12423800 & -1.94813000 & -0.69710800 \\
\hline $\mathrm{H}$ & -7.68746000 & -1.27015700 & -1.97696200 \\
\hline $\mathrm{H}$ & 7.68715400 & -1.26957400 & 1.97659000 \\
\hline S & -5.54590900 & 0.06200400 & -0.02244700 \\
\hline $\mathrm{F}$ & -6.32749900 & 2.09707600 & 2.11185500 \\
\hline B & -7.53573800 & 2.16057500 & 1.42769100 \\
\hline $\mathrm{F}$ & -8.35460800 & 1.09125000 & 1.77013700 \\
\hline $\mathrm{N}$ & -8.25919500 & 3.50849800 & 1.73043500 \\
\hline $\mathrm{N}$ & -7.26910400 & 2.15225400 & -0.12239200 \\
\hline $\mathrm{C}$ & -8.81435000 & 4.35969300 & 0.77346600 \\
\hline $\mathrm{C}$ & -8.55492400 & 4.00870800 & 2.94291100 \\
\hline $\mathrm{C}$ & -7.85446500 & 3.03962500 & -1.02907400 \\
\hline $\mathrm{C}$ & -6.53829300 & 1.26977900 & -0.83792100 \\
\hline $\mathrm{C}$ & -8.62213500 & 4.11175900 & -0.58298700 \\
\hline $\mathrm{C}$ & -9.47467900 & 5.41616000 & 1.45119700 \\
\hline $\mathrm{C}$ & -9.30736300 & 5.19416500 & 2.81314000 \\
\hline $\mathrm{C}$ & -7.46678700 & 2.66064100 & -2.33898900 \\
\hline $\mathrm{C}$ & -6.63551300 & 1.55999900 & -2.22338200 \\
\hline $\mathrm{H}$ & -9.99180600 & 6.23670700 & 0.97162700 \\
\hline $\mathrm{H}$ & -9.66959500 & 5.80231400 & 3.63035300 \\
\hline $\mathrm{H}$ & -7.75602500 & 3.17249200 & -3.24734400 \\
\hline $\mathrm{H}$ & -6.13061400 & 1.02317100 & -3.01284100 \\
\hline $\mathrm{H}$ & -8.22467800 & 3.50879600 & 3.84384500 \\
\hline
\end{tabular}




$\begin{array}{lrrr}\text { H } & 4.40518400 & -4.92421000 & 3.20629300 \\ \mathrm{H} & -4.40420800 & -4.92323000 & -3.20789300 \\ \mathrm{H} & -9.06041200 & 4.78394700 & -1.31357800 \\ \mathrm{~S} & 5.54509500 & 0.06261900 & 0.02278600 \\ \mathrm{~F} & 8.35361100 & 1.09116300 & -1.77044300 \\ \mathrm{~B} & 7.53532000 & 2.16082300 & -1.42767600 \\ \mathrm{~F} & 6.32697800 & 2.09808000 & -2.11165300 \\ \mathrm{~N} & 7.26899800 & 2.15241500 & 0.12249500 \\ \mathrm{~N} & 8.25939000 & 3.50843700 & -1.73031700 \\ \mathrm{C} & 7.85505800 & 3.03936000 & 1.02915000 \\ \mathrm{C} & 6.53836900 & 1.26990100 & 0.83817600 \\ \mathrm{C} & 8.81498700 & 4.35942200 & -0.77340500 \\ \mathrm{C} & 8.55489600 & 4.00865400 & -2.94280400 \\ \mathrm{C} & 8.62296400 & 4.11135000 & 0.58303200 \\ \mathrm{C} & 7.46797600 & 2.66010800 & 2.33913400 \\ \mathrm{C} & 6.63631000 & 1.55972100 & 2.22366000 \\ \mathrm{C} & 9.47533000 & 5.41582800 & -1.45125200 \\ \mathrm{C} & 9.30761700 & 5.19397100 & -2.81315800 \\ \mathrm{H} & 9.06159700 & 4.78324800 & 1.31367700 \\ \mathrm{H} & 7.75785100 & 3.17159600 & 3.24748800 \\ \mathrm{H} & 6.13175800 & 1.02282800 & 3.01329800 \\ \mathrm{H} & 9.99274000 & 6.23622700 & -0.97173700 \\ \mathrm{H} & 9.66975700 & 5.80209300 & -3.63043100 \\ \mathrm{H} & 8.22438500 & 3.50886600 & -3.84371900 \\ \mathrm{SCF} & & & \end{array}$

SCF done: -3916.50121941 Hartree

No imaginary Frequency.

\section{B2, optimized $\mathrm{T}_{1}$ state Geometry.}

$\begin{array}{lrrc}\text { S } & 0.00000100 & 0.35034500 & 0.00000000 \\ \mathrm{~F} & -2.56118800 & 1.97892900 & 0.05179600 \\ \mathrm{~F} & 2.89619200 & 0.67448700 & -1.89821800 \\ \mathrm{~F} & 2.56119300 & 1.97893100 & -0.05174300 \\ \mathrm{~F} & -2.89620300 & 0.67443500 & 1.89823300 \\ \mathrm{~N} & -2.58606600 & -0.42275600 & -0.24447600 \\ \mathrm{~N} & 2.58606700 & -0.42276100 & 0.24446600 \\ \mathrm{~N} & -4.67908300 & 0.81694300 & 0.26532600 \\ \mathrm{~N} & 4.67908400 & 0.81694300 & -0.26532200 \\ \mathrm{C} & 3.35377900 & -1.43948900 & 0.77923500 \\ \mathrm{C} & 1.18596400 & -2.00810400 & 1.10999700 \\ \mathrm{H} & 0.26947800 & -2.48900300 & 1.41933800 \\ \mathrm{C} & 1.27042700 & -0.75365700 & 0.44182100 \\ \mathrm{C} & -5.40219600 & -0.23272200 & -0.28994500 \\ \mathrm{C} & -3.35377900 & -1.43948000 & -0.77925400 \\ \mathrm{C} & 4.75561800 & -1.36466000 & 0.78679300 \\ \mathrm{C} & -4.75561800 & -1.36465000 & -0.78680700 \\ \mathrm{C} & 2.48002300 & -2.43807300 & 1.31442900 \\ \mathrm{H} & 2.80343800 & -3.33820400 & 1.81935600 \\ \mathrm{C} & 5.40219600 & -0.23272600 & 0.28994200 \\ \mathrm{C} & -6.78750100 & 0.12137200 & -0.26241300 \\ \mathrm{H} & -7.59226500 & -0.49749400 & -0.63586200 \\ \mathrm{C} & -2.48002500 & -2.43805800 & -1.31445900 \\ \mathrm{H} & -2.80344000 & -3.33818300 & -1.81939400 \\ \mathrm{C} & 6.78750200 & 0.12136500 & 0.26241000 \\ \mathrm{H} & 7.59226500 & -0.49750600 & 0.63585400 \\ \mathrm{C} & -1.18596500 & -2.00809200 & -1.11002300 \\ \mathrm{H} & -0.26948000 & -2.48898700 & -1.41937100\end{array}$




$\begin{array}{lrrr}\text { C } & -1.27042700 & -0.75365100 & -0.44183600 \\ \text { C } & 5.55987700 & 1.78518600 & -0.62229200 \\ \text { C } & -5.55987400 & 1.78518500 & 0.62230200 \\ \text { C } & 6.87510500 & 1.38341400 & -0.30596800 \\ \text { C } & -6.87510200 & 1.38341900 & 0.30597200 \\ \text { B } & 3.15157100 & 0.81319100 & -0.53643100 \\ \text { B } & -3.15157200 & 0.81317800 & 0.53644800 \\ \text { H } & -7.76795300 & 1.96890700 & 0.47705200 \\ \text { H } & -5.21758100 & 2.70332500 & 1.08009100 \\ \text { H } & 5.21758600 & 2.70332900 & -1.08007600 \\ \text { H } & 7.76795800 & 1.96890100 & -0.47704600 \\ \text { H } & -5.33150300 & -2.17576100 & -1.21555700 \\ \text { H } & 5.33150200 & -2.17577400 & 1.21553700\end{array}$

SCF done: -1759.70909494 Hartree

No imaginary Frequency.

B3, optimized $\mathrm{T}_{1}$ state Geometry.

\begin{tabular}{|c|c|c|c|}
\hline S & 2.99757200 & 0.37073000 & 0.18889400 \\
\hline $\mathrm{F}$ & 0.03672100 & 0.65285000 & 1.06224500 \\
\hline $\mathrm{F}$ & 5.78762200 & -0.63141000 & 2.02885700 \\
\hline $\mathrm{F}$ & 4.41805600 & -2.18283300 & 1.05425700 \\
\hline $\mathrm{F}$ & -0.03694400 & 0.75432800 & -1.21900900 \\
\hline $\mathrm{N}$ & 1.24587200 & 2.44005000 & -0.00827900 \\
\hline $\mathrm{N}$ & 5.48550100 & -0.54379500 & -0.37618200 \\
\hline $\mathrm{N}$ & -1.24371300 & 2.44204300 & 0.00660700 \\
\hline $\mathrm{N}$ & 6.80722800 & -2.37253100 & 0.69186500 \\
\hline $\mathrm{C}$ & 6.48832200 & -0.42929000 & -1.33607300 \\
\hline $\mathrm{C}$ & 4.84110100 & 1.00534200 & -1.91436000 \\
\hline $\mathrm{H}$ & 4.21672200 & 1.72443800 & -2.42376200 \\
\hline $\mathrm{C}$ & 4.49449200 & 0.31305800 & -0.72359600 \\
\hline $\mathrm{C}$ & -1.20890500 & 3.82119400 & 0.03727500 \\
\hline $\mathrm{C}$ & 1.21503900 & 3.81930600 & 0.00661400 \\
\hline $\mathrm{C}$ & 7.62091900 & -1.24339700 & -1.28749100 \\
\hline $\mathrm{C}$ & 0.00362800 & 4.52375300 & 0.02932000 \\
\hline $\mathrm{C}$ & 6.08997500 & 0.54461300 & -2.28967200 \\
\hline $\mathrm{H}$ & 6.66058900 & 0.83129000 & -3.16294600 \\
\hline $\mathrm{C}$ & 7.77460400 & -2.21380100 & -0.30153600 \\
\hline $\mathrm{C}$ & -2.55970200 & 4.30992900 & 0.05366000 \\
\hline $\mathrm{H}$ & -2.83790200 & 5.35491100 & 0.06851400 \\
\hline C & 2.56713800 & 4.30410900 & 0.02703600 \\
\hline $\mathrm{H}$ & 2.84838400 & 5.34804600 & 0.05328600 \\
\hline $\mathrm{C}$ & 8.78000500 & -3.19763000 & -0.10024000 \\
\hline $\mathrm{H}$ & 9.65600400 & -3.32761500 & -0.72172100 \\
\hline $\mathrm{C}$ & 3.40077800 & 3.20661400 & 0.04532300 \\
\hline $\mathrm{H}$ & 4.48009800 & 3.19454000 & 0.09192900 \\
\hline $\mathrm{C}$ & 2.56984000 & 2.05339800 & 0.02532000 \\
\hline $\mathrm{C}$ & 7.18567700 & -3.40240400 & 1.47129900 \\
\hline $\mathrm{C}$ & -2.56944900 & 2.06047100 & -0.01800600 \\
\hline $\mathrm{C}$ & 8.40520600 & -3.94222000 & 1.01056400 \\
\hline $\mathrm{C}$ & -3.39692600 & 3.21586000 & 0.01339500 \\
\hline B & 5.58249300 & -1.43583400 & 0.91392600 \\
\hline B & 0.00031000 & 1.50405800 & -0.04282500 \\
\hline $\mathrm{H}$ & -4.47696600 & 3.20778600 & -0.01389800 \\
\hline $\mathrm{H}$ & 6.58244900 & -3.70922300 & 2.31540300 \\
\hline $\mathrm{H}$ & 8.92743500 & -4.78078200 & 1.44987500 \\
\hline$S$ & -3.00704600 & 0.38527700 & -0.22636000 \\
\hline
\end{tabular}




\begin{tabular}{lrrr} 
F & -4.44656800 & -2.14485100 & -1.12062100 \\
B & -5.60862800 & -1.40565800 & -0.92856000 \\
F & -5.84682900 & -0.57302700 & -2.01586900 \\
N & -6.82454200 & -2.35142800 & -0.69709800 \\
N & -5.47782100 & -0.54761400 & 0.38136700 \\
C & -7.76646700 & -2.21861000 & 0.32418000 \\
C & -7.22155200 & -3.36268800 & -1.49158400 \\
C & -6.45543600 & -0.45861000 & 1.36954200 \\
C & -4.47774200 & 0.29994800 & 0.72535500 \\
C & -7.58839500 & -1.27257200 & 1.32963900 \\
C & -8.77543300 & -3.19910500 & 0.12470800 \\
C & -8.42817900 & -3.91580400 & -1.01314500 \\
C & -6.03205600 & 0.49009800 & 2.33769000 \\
C & -4.79302400 & 0.96063600 & 1.94257000 \\
H & -9.63489400 & -3.34614000 & 0.76519700 \\
H & -8.96037500 & -4.74450100 & -1.45916900 \\
H & -6.57969000 & 0.75367200 & 3.23267300 \\
H & -4.15535800 & 1.66625300 & 2.45432100 \\
H & -6.63970100 & -3.64767300 & -2.35805500 \\
H & 8.38309000 & -1.13309600 & -2.05159200 \\
H & 0.00459000 & 5.60576100 & 0.04764700 \\
H & -8.33070200 & -1.18239000 & 2.11562300 \\
\hline$C F$
\end{tabular}

SCF done: -2838.08438332 Hartree

No imaginary Frequency.

B4, optimized $\mathrm{T}_{1}$ state Geometry.

$\begin{array}{lrrc}\text { S } & 0.00002700 & -2.35568100 & 0.00002100 \\ \mathrm{~F} & 2.48055300 & -0.78246400 & 1.11439200 \\ \mathrm{~F} & -3.25300800 & -1.95424100 & 0.68989500 \\ \mathrm{~F} & -2.48046300 & -0.78232400 & -1.11423700 \\ \mathrm{~F} & 3.25300900 & -1.95412700 & -0.68994300 \\ \mathrm{~N} & 2.30080600 & -3.18456700 & 1.18542100 \\ \mathrm{~N} & -2.30069900 & -3.18441700 & -1.18559000 \\ \mathrm{~N} & 4.53403900 & -2.07798800 & 1.34923100 \\ \mathrm{~N} & -4.53393100 & -2.07781900 & -1.34936300 \\ \mathrm{C} & -2.77587600 & -4.19119900 & -2.01107800 \\ \mathrm{C} & -0.62012600 & -4.68979400 & -1.53108800 \\ \mathrm{H} & 0.36226500 & -5.13714000 & -1.48720800 \\ \mathrm{C} & -0.99364400 & -3.47041600 & -0.90204600 \\ \mathrm{C} & 4.93849500 & -3.10373200 & 2.19324300 \\ \mathrm{C} & 2.77602900 & -4.19146300 & 2.01073700 \\ \mathrm{C} & -4.07753100 & -4.15338600 & -2.52003400 \\ \mathrm{C} & 4.07771200 & -4.15372300 & 2.51963300 \\ \mathrm{C} & -1.72856100 & -5.13944500 & -2.21922600 \\ \mathrm{H} & -1.80768200 & -6.02513600 & -2.83500600 \\ \mathrm{C} & -4.93833800 & -3.10344800 & -2.19354700 \\ \mathrm{C} & 6.29445600 & -2.86862900 & 2.57101900 \\ \mathrm{H} & 6.87728100 & -3.50924500 & 3.21899900 \\ \mathrm{C} & 1.72872500 & -5.13974700 & 2.21880300 \\ \mathrm{H} & 1.80788200 & -6.02552500 & 2.83445200 \\ \mathrm{C} & -6.29427300 & -2.86829800 & -2.57136200 \\ \mathrm{H} & -6.87706300 & -3.50882500 & -3.21946200 \\ \mathrm{C} & 0.62025800 & -4.69000900 & 1.53077600 \\ \mathrm{H} & -0.36213000 & -5.13735800 & 1.48687400 \\ \mathrm{C} & 0.99373500 & -3.47053600 & 0.90189300 \\ \mathrm{C} & -5.60096200 & -1.24156400 & -1.18095900\end{array}$




\begin{tabular}{|c|c|c|c|}
\hline $\mathrm{C}$ & 5.60106500 & -1.24170600 & 1.18087800 \\
\hline $\mathrm{C}$ & -6.70730500 & -1.71354200 & -1.93588200 \\
\hline $\mathrm{C}$ & 6.70744700 & -1.71378200 & 1.93568200 \\
\hline B & -3.12024700 & -1.94677800 & -0.69692500 \\
\hline B & 3.12032300 & -1.94685900 & 0.69688600 \\
\hline $\mathrm{H}$ & 7.68218100 & -1.24931100 & 1.96991000 \\
\hline $\mathrm{H}$ & -7.68204100 & -1.24907500 & -1.97009200 \\
\hline S & 5.52283000 & 0.08555400 & 0.03924600 \\
\hline $\mathrm{F}$ & 6.30848700 & 2.12117300 & -2.09704000 \\
\hline B & 7.52417100 & 2.16546000 & -1.42425800 \\
\hline $\mathrm{F}$ & 8.32330000 & 1.08478300 & -1.77785000 \\
\hline $\mathrm{N}$ & 8.26421200 & 3.50351500 & -1.72779200 \\
\hline $\mathrm{N}$ & 7.27119400 & 2.15588400 & 0.12741400 \\
\hline $\mathrm{C}$ & 8.83724400 & 4.34421200 & -0.77208100 \\
\hline $\mathrm{C}$ & 8.55852700 & 4.00345700 & -2.94127700 \\
\hline $\mathrm{C}$ & 7.87397800 & 3.02982500 & 1.03238200 \\
\hline $\mathrm{C}$ & 6.53187000 & 1.27933300 & 0.84541900 \\
\hline $\mathrm{C}$ & 8.65367000 & 4.09517800 & 0.58497500 \\
\hline $\mathrm{C}$ & 9.50774800 & 5.39445500 & -1.45236300 \\
\hline $\mathrm{C}$ & 9.32814900 & 5.17867400 & -2.81302400 \\
\hline $\mathrm{C}$ & 7.49026500 & 2.65178100 & 2.34484600 \\
\hline $\mathrm{C}$ & 6.64389000 & 1.56295600 & 2.23176400 \\
\hline $\mathrm{H}$ & 10.03928700 & 6.20627700 & -0.97380300 \\
\hline $\mathrm{H}$ & 9.69283600 & 5.78410900 & -3.63115300 \\
\hline $\mathrm{H}$ & 7.79099100 & 3.15834800 & 3.25233600 \\
\hline $\mathrm{H}$ & 6.13465300 & 1.03188700 & 3.02238800 \\
\hline $\mathrm{H}$ & 8.21542000 & 3.51089000 & -3.84141400 \\
\hline $\mathrm{H}$ & -4.42133000 & -4.94607700 & -3.17350800 \\
\hline $\mathrm{H}$ & 4.42154800 & -4.94650500 & 3.17297600 \\
\hline $\mathrm{H}$ & 9.10607100 & 4.75888200 & 1.31441900 \\
\hline$S$ & -5.52278900 & 0.08553200 & -0.03912300 \\
\hline $\mathrm{F}$ & -8.32393300 & 1.08423800 & 1.77723900 \\
\hline B & -7.52462500 & 2.16499600 & 1.42430000 \\
\hline $\mathrm{F}$ & -6.30919200 & 2.12043200 & 2.09751500 \\
\hline $\mathrm{N}$ & -7.27107600 & 2.15591800 & -0.12728100 \\
\hline $\mathrm{N}$ & -8.26471900 & 3.50298500 & 1.72799800 \\
\hline $\mathrm{C}$ & -7.87351800 & 3.03016100 & -1.03218700 \\
\hline $\mathrm{C}$ & -6.53152000 & 1.27957700 & -0.84529800 \\
\hline $\mathrm{C}$ & -8.83738800 & 4.34400300 & 0.77235100 \\
\hline $\mathrm{C}$ & -8.55944400 & 4.00255300 & 2.94153700 \\
\hline $\mathrm{C}$ & -8.65333900 & 4.09539300 & -0.58471900 \\
\hline $\mathrm{C}$ & -7.48934600 & 2.65252300 & -2.34463300 \\
\hline $\mathrm{C}$ & -6.64303900 & 1.56364000 & -2.23159300 \\
\hline $\mathrm{C}$ & -9.50809600 & 5.39405200 & 1.45272800 \\
\hline $\mathrm{C}$ & -9.32898200 & 5.17783500 & 2.81338500 \\
\hline $\mathrm{H}$ & -9.10546000 & 4.75934100 & -1.31411500 \\
\hline $\mathrm{H}$ & -7.78973400 & 3.15938600 & -3.25206900 \\
\hline $\mathrm{H}$ & -6.13353100 & 1.03281200 & -3.02220500 \\
\hline $\mathrm{H}$ & -10.03944100 & 6.20604300 & 0.97423900 \\
\hline $\mathrm{H}$ & -9.69393700 & 5.78302400 & 3.63157600 \\
\hline $\mathrm{H}$ & -8.21667000 & 3.50968900 & 3.84163800 \\
\hline
\end{tabular}

SCF done: -3916.45709682 Hartree No imaginary Frequency. 
9. Copies of ${ }^{1} \mathrm{H}$ and ${ }^{13} \mathrm{C}$ NMR spectra

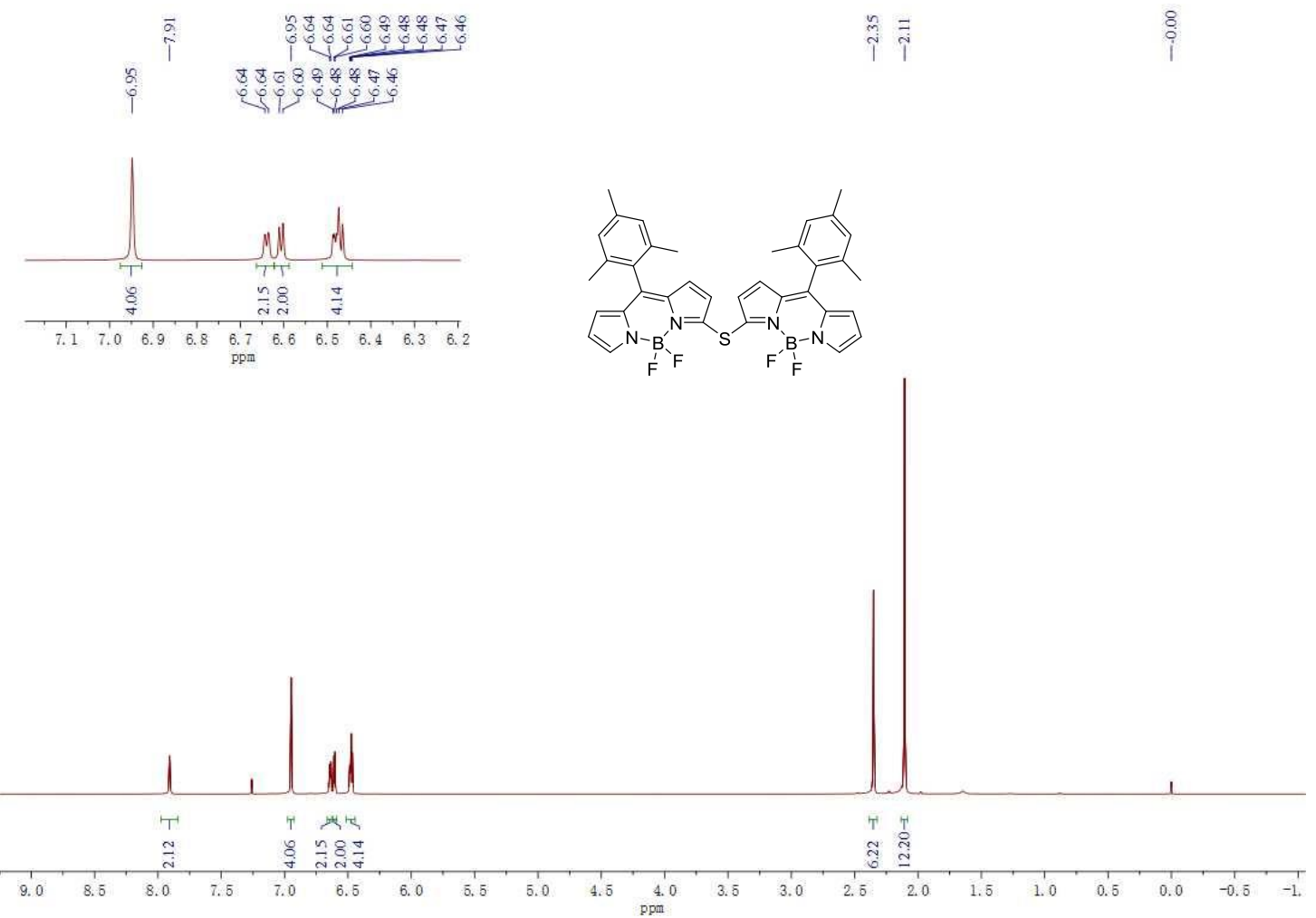

${ }^{1} \mathrm{H}$ NMR spectrum of $\mathbf{B 2}\left(\mathrm{CDCl}_{3}, 500 \mathrm{MHz}\right)$
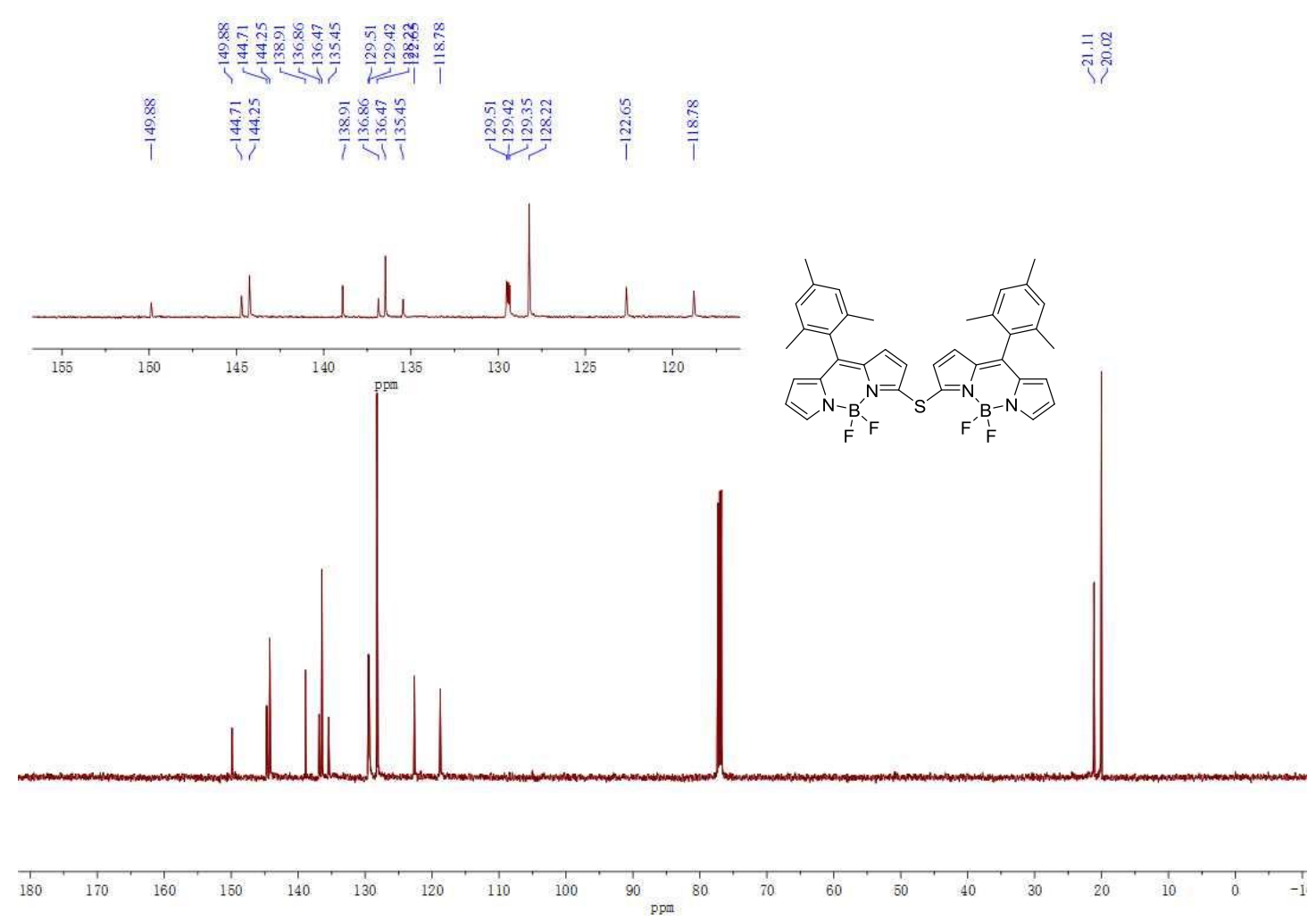

${ }^{13} \mathrm{C}$ NMR spectrum of $\mathbf{B 2}\left(\mathrm{CDCl}_{3}, 126 \mathrm{MHz}\right)$ 


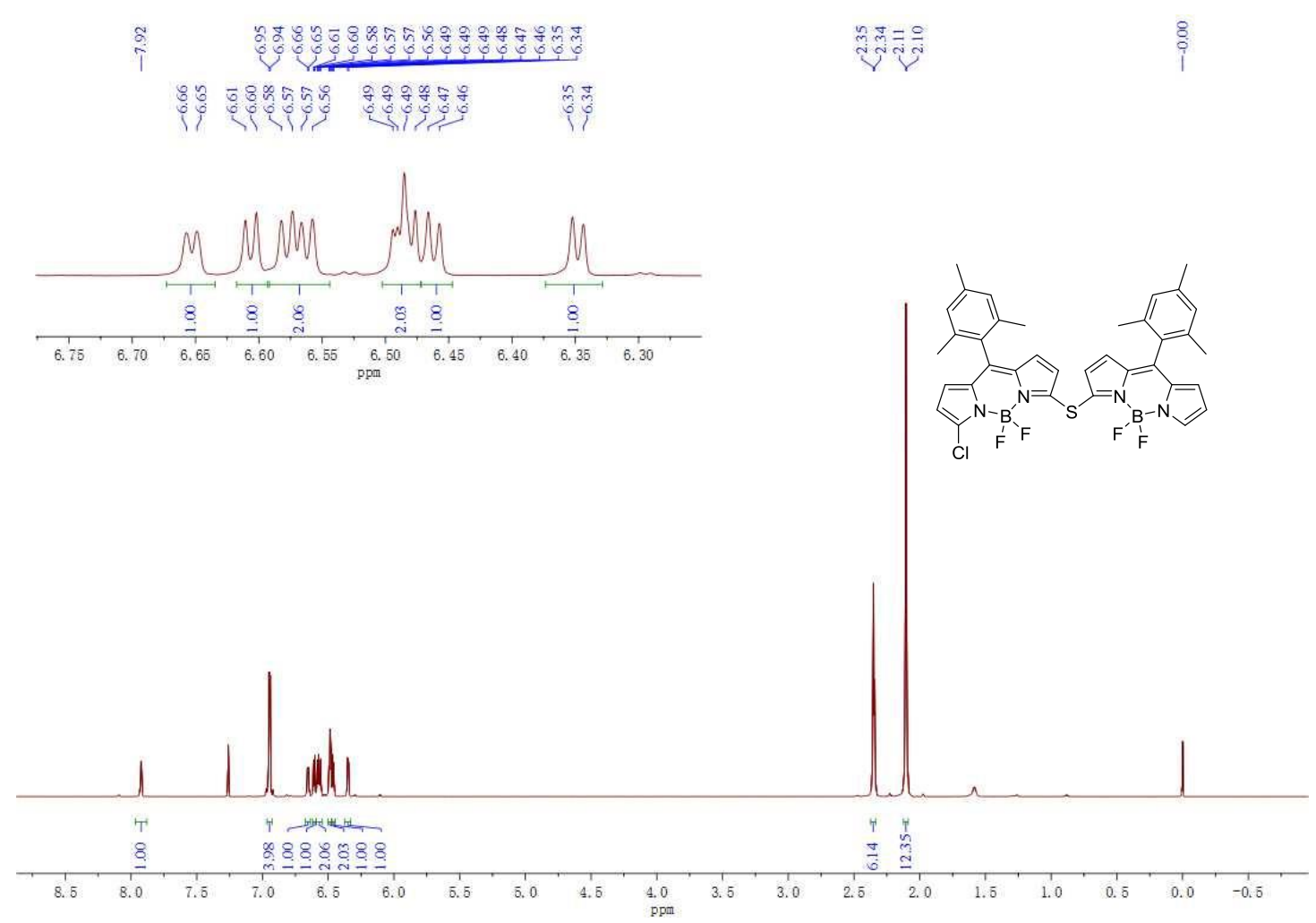

${ }^{1} \mathrm{H}$ NMR spectrum of $\mathbf{B 2 - 1 C l}\left(\mathrm{CDCl}_{3}, 500 \mathrm{MHz}\right)$

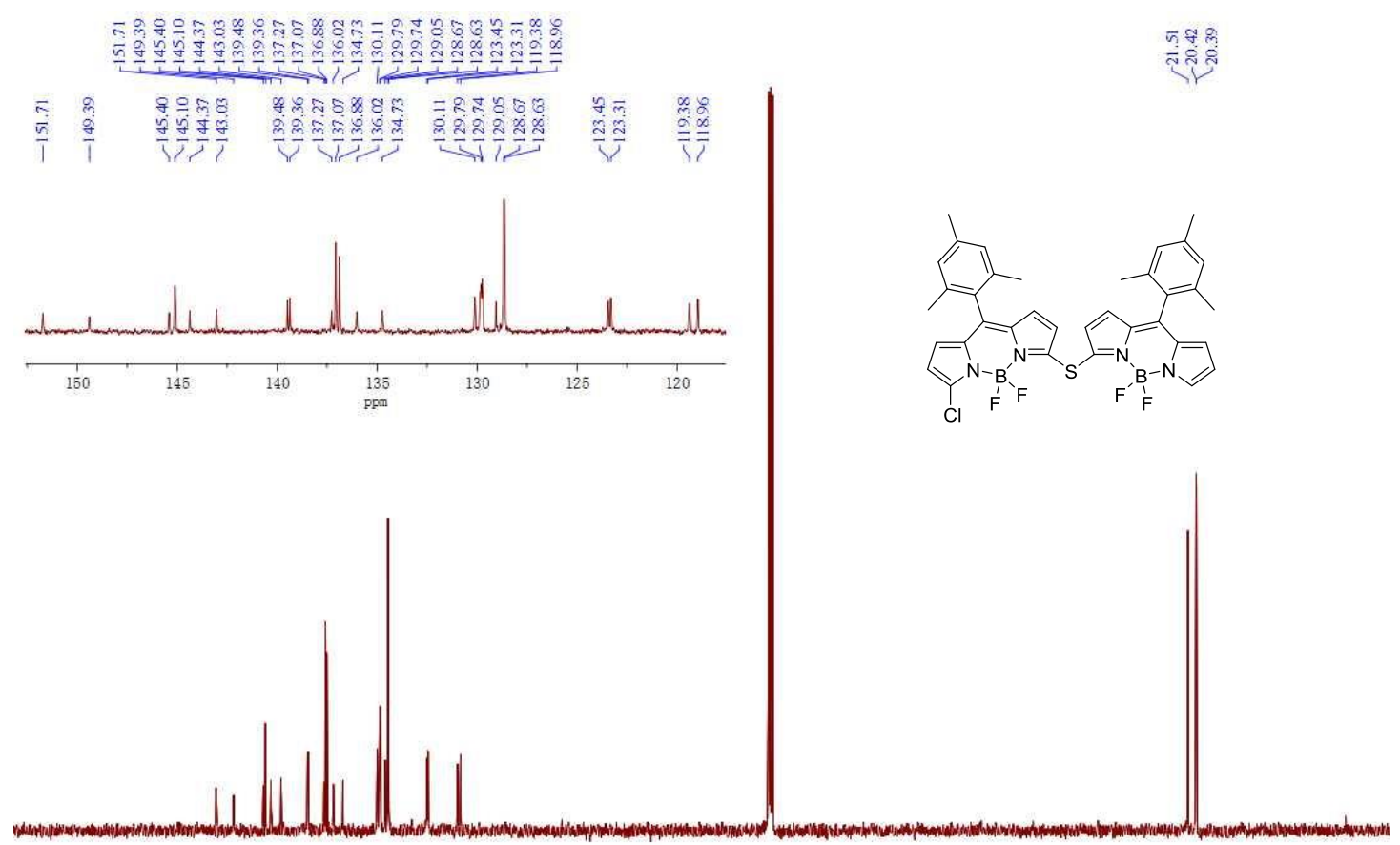

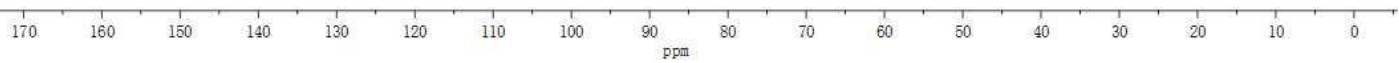

${ }^{13} \mathrm{C}$ NMR spectrum of $\mathbf{B 2 - 1 C l}\left(\mathrm{CDCl}_{3}, 126 \mathrm{MHz}\right)$ 


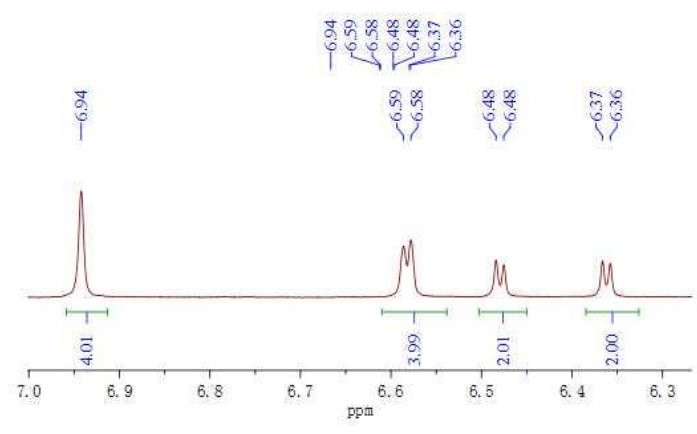

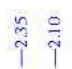
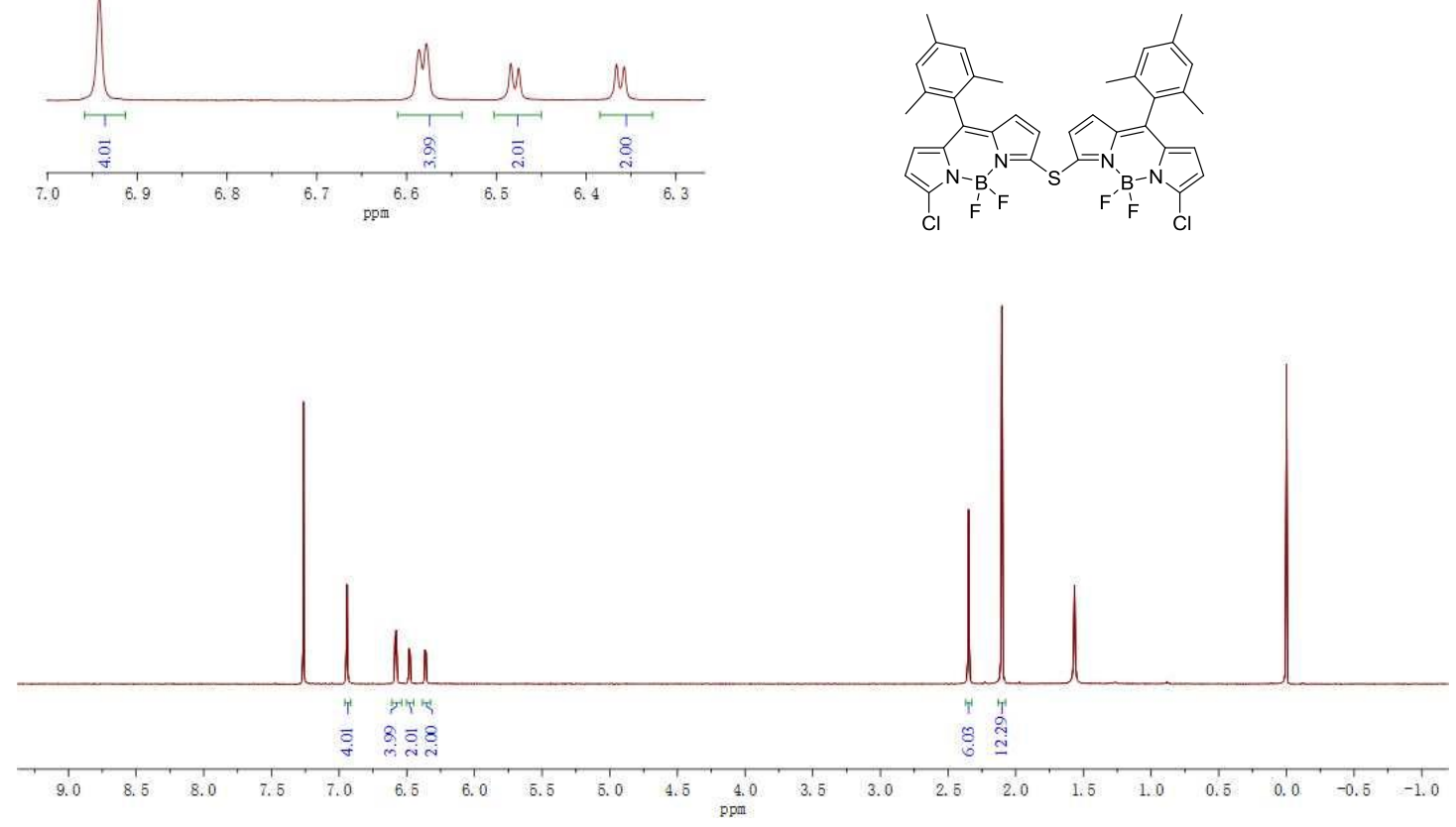

${ }^{1} \mathrm{H}$ NMR spectrum of $\mathbf{B 2 - 2 C l}\left(\mathrm{CDCl}_{3}, 500 \mathrm{MHz}\right)$
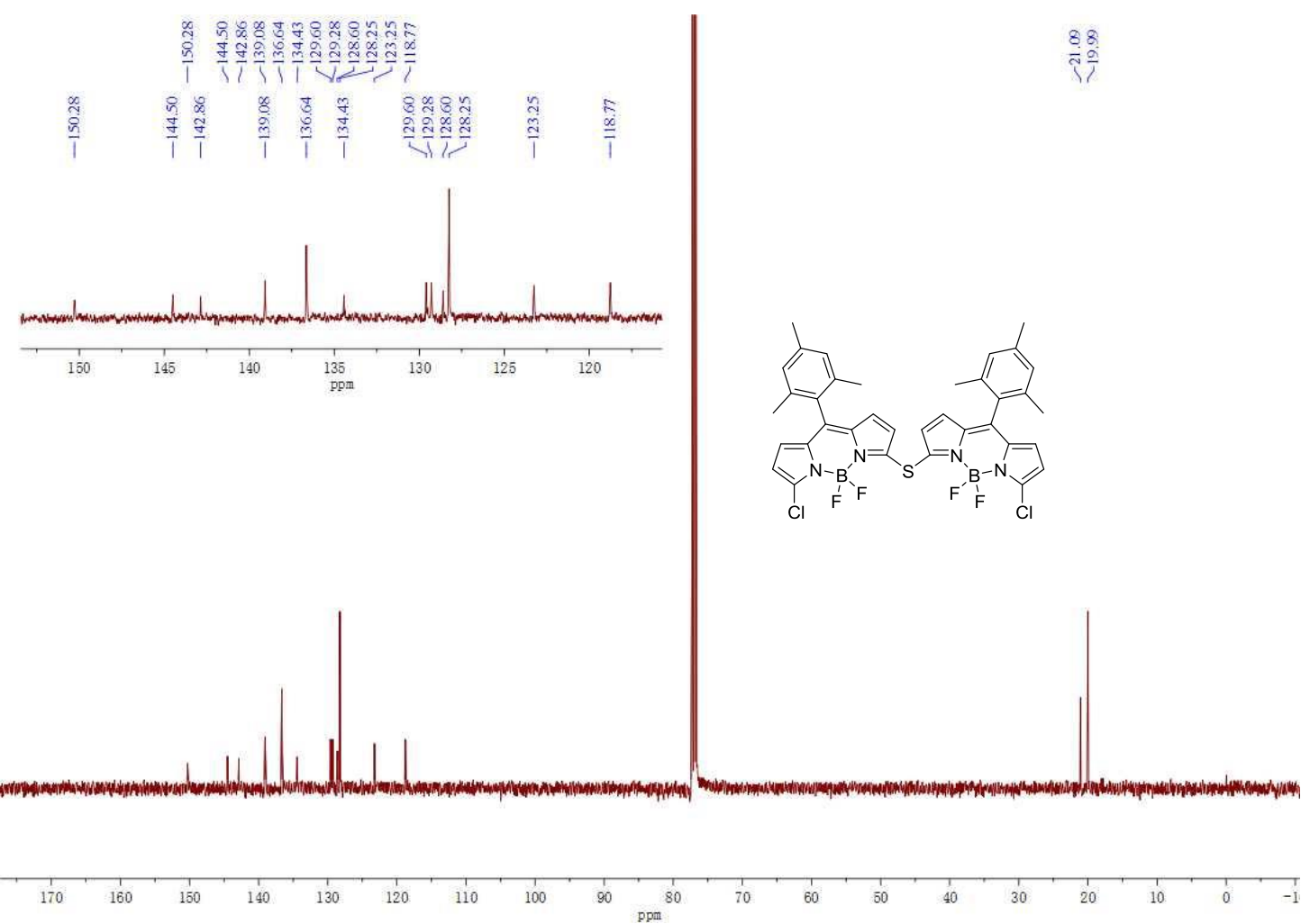

${ }^{13} \mathrm{C}$ NMR spectrum of $\mathbf{B 2 - 2 C l}\left(\mathrm{CDCl}_{3}, 126 \mathrm{MHz}\right)$ 

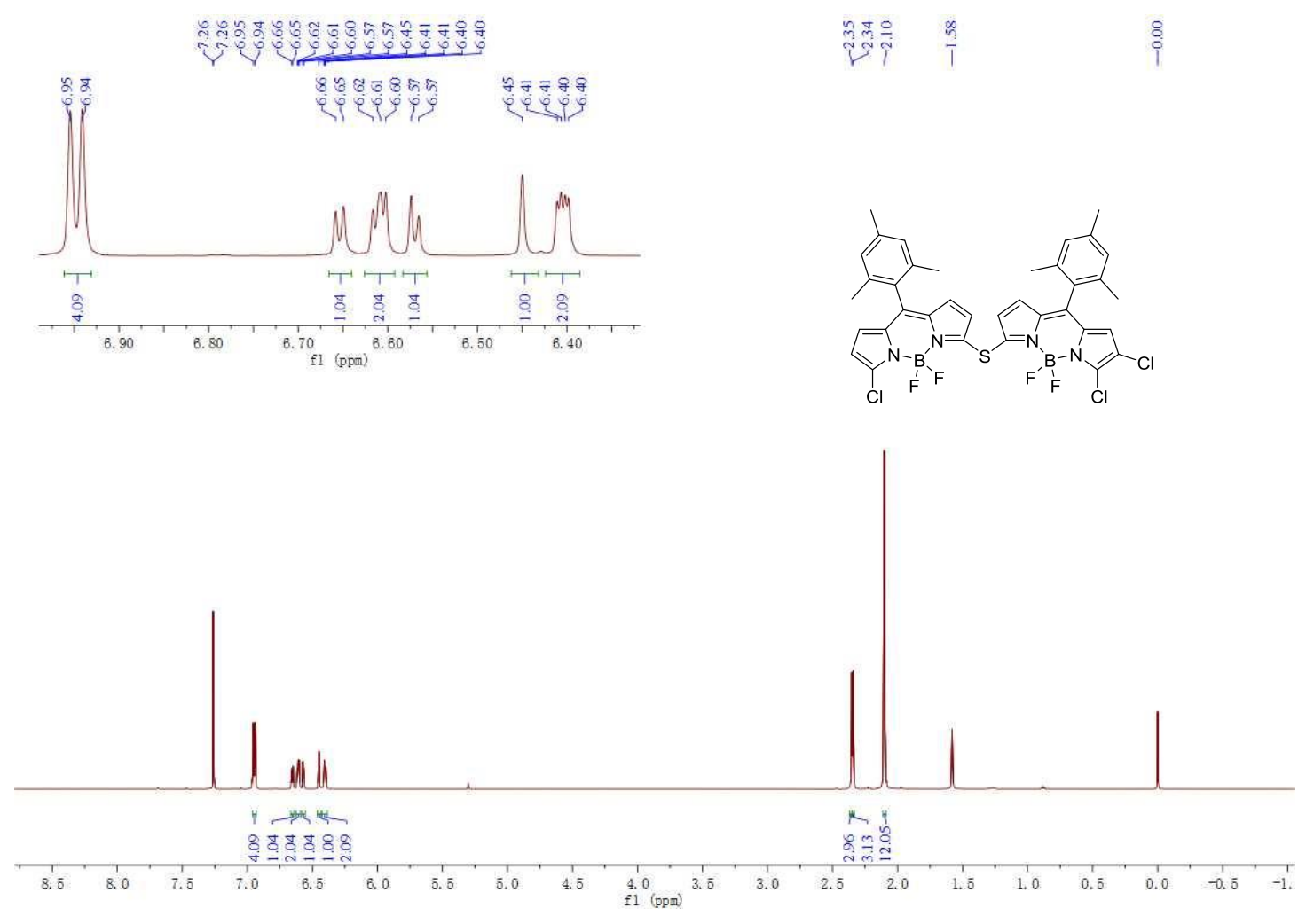

${ }^{1} \mathrm{H}$ NMR spectrum of $\mathbf{B 2 - 3 C l}\left(\mathrm{CDCl}_{3}, 500 \mathrm{MHz}\right)$
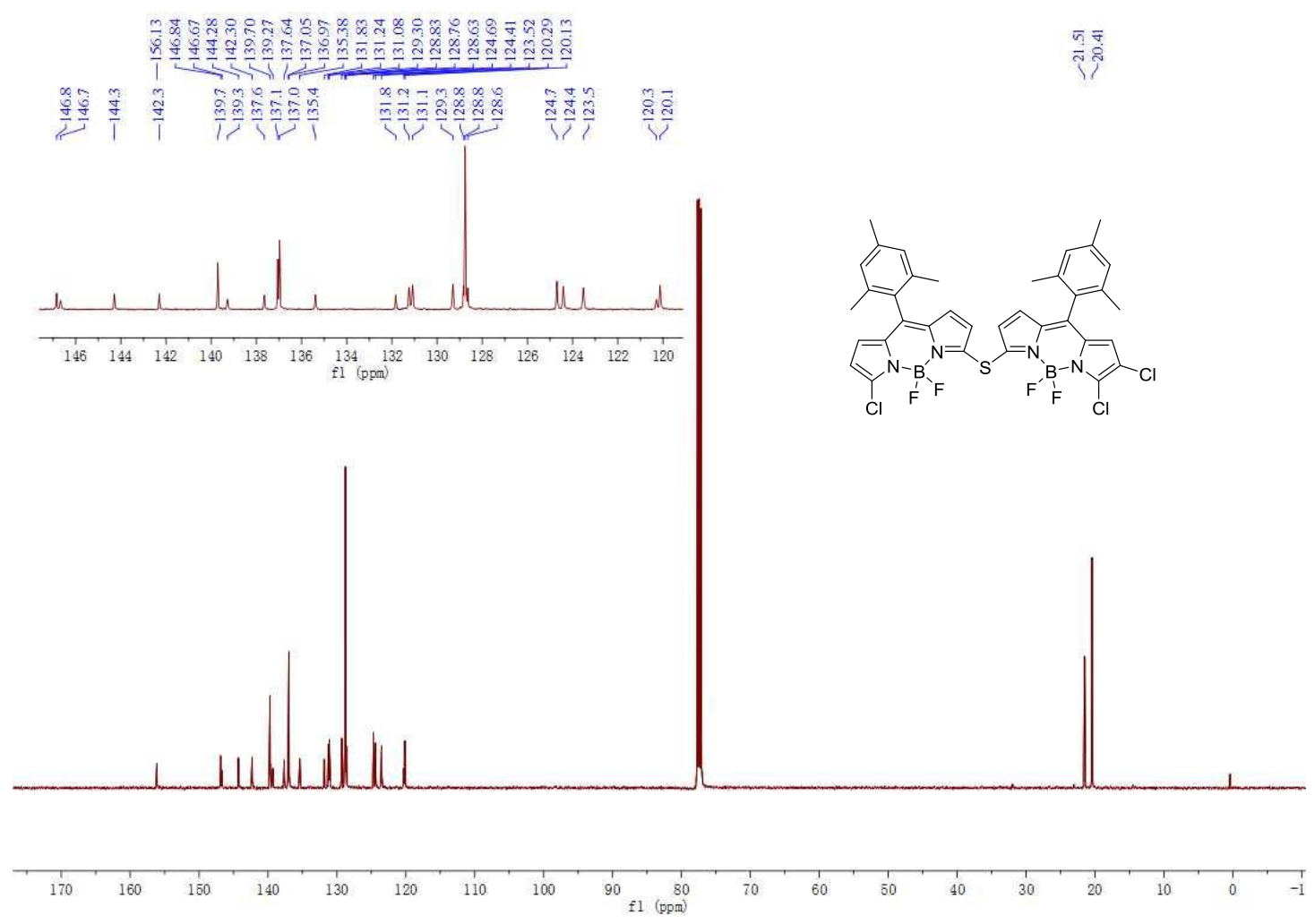

${ }^{13} \mathrm{C}$ NMR spectrum of $\mathbf{B 2}-3 \mathbf{C l}\left(\mathrm{CDCl}_{3}, 126 \mathrm{MHz}\right)$ 


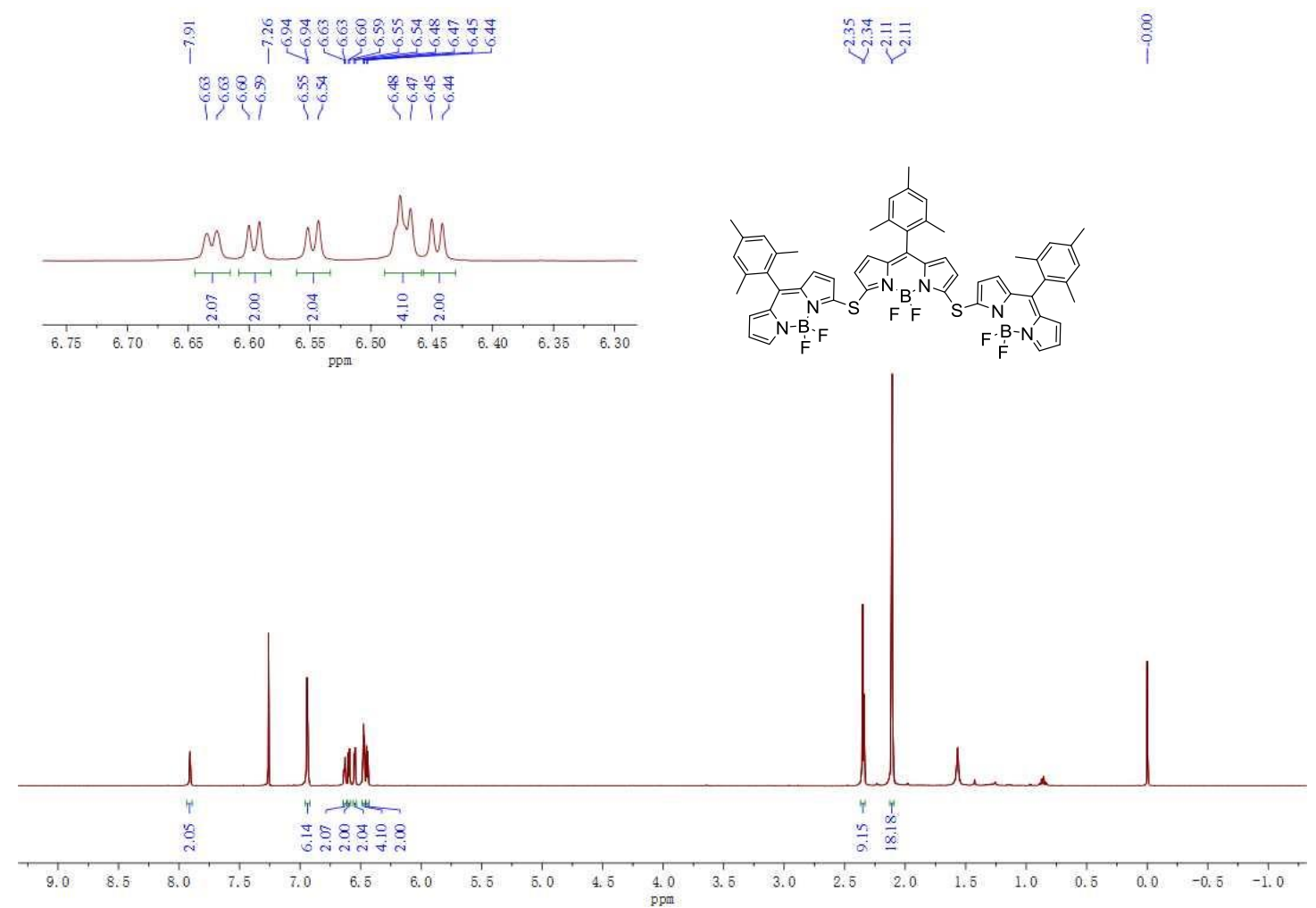

${ }^{1} \mathrm{H}$ NMR spectrum of $\mathbf{B 3}\left(\mathrm{CDCl}_{3}, 500 \mathrm{MHz}\right)$

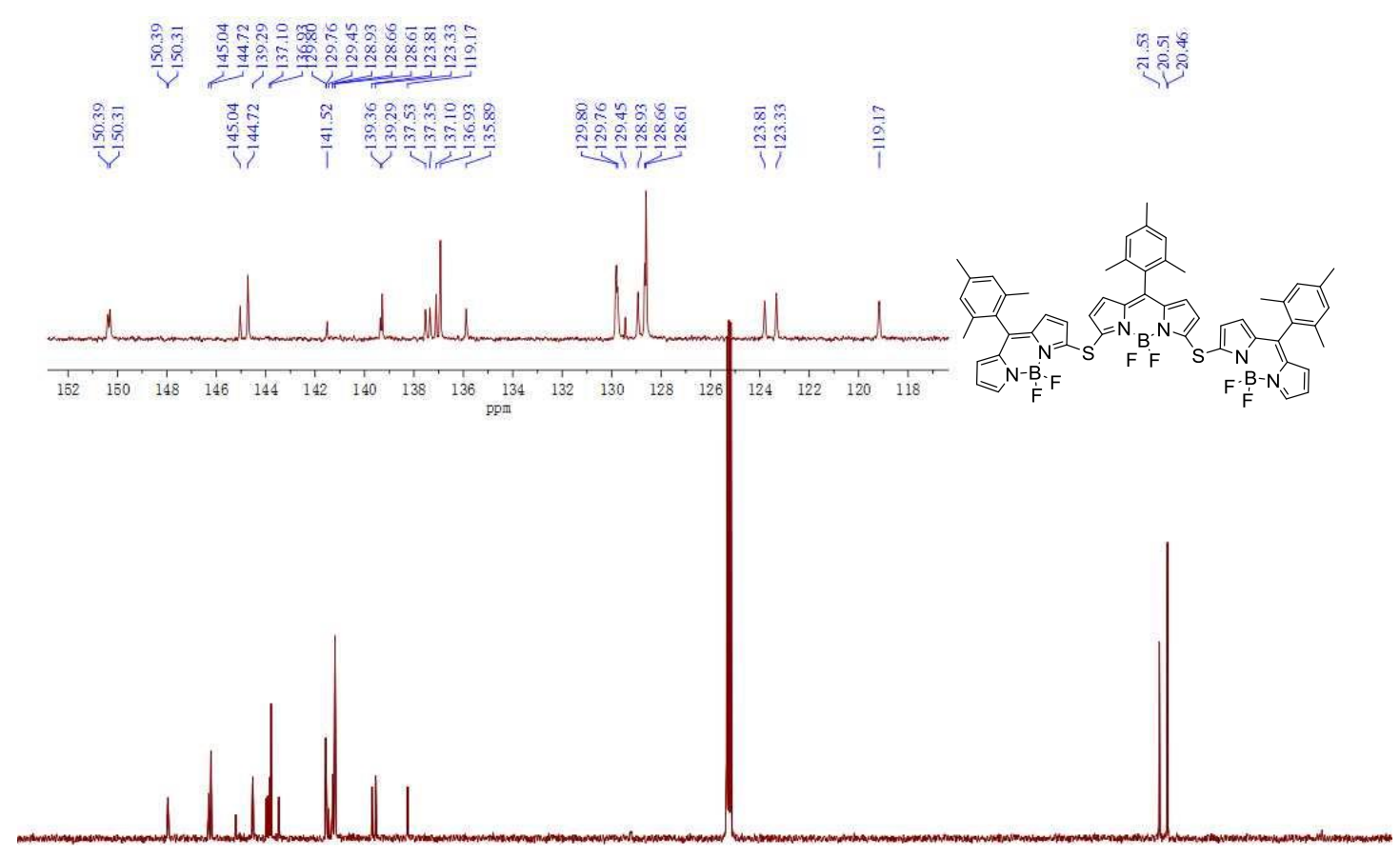

$\begin{array}{rrrrrrrrr}1 & 1 & 1 & 1 & 1 & 1 & 1 & 1 \\ 160 & 150 & 140 & 130 & 120 & 110 & 100 & 90 & 80 \\ \text { ppm }\end{array}$

${ }^{13} \mathrm{C}$ NMR spectrum of $\mathbf{B 3}\left(\mathrm{CDCl}_{3}, 126 \mathrm{MHz}\right)$ 


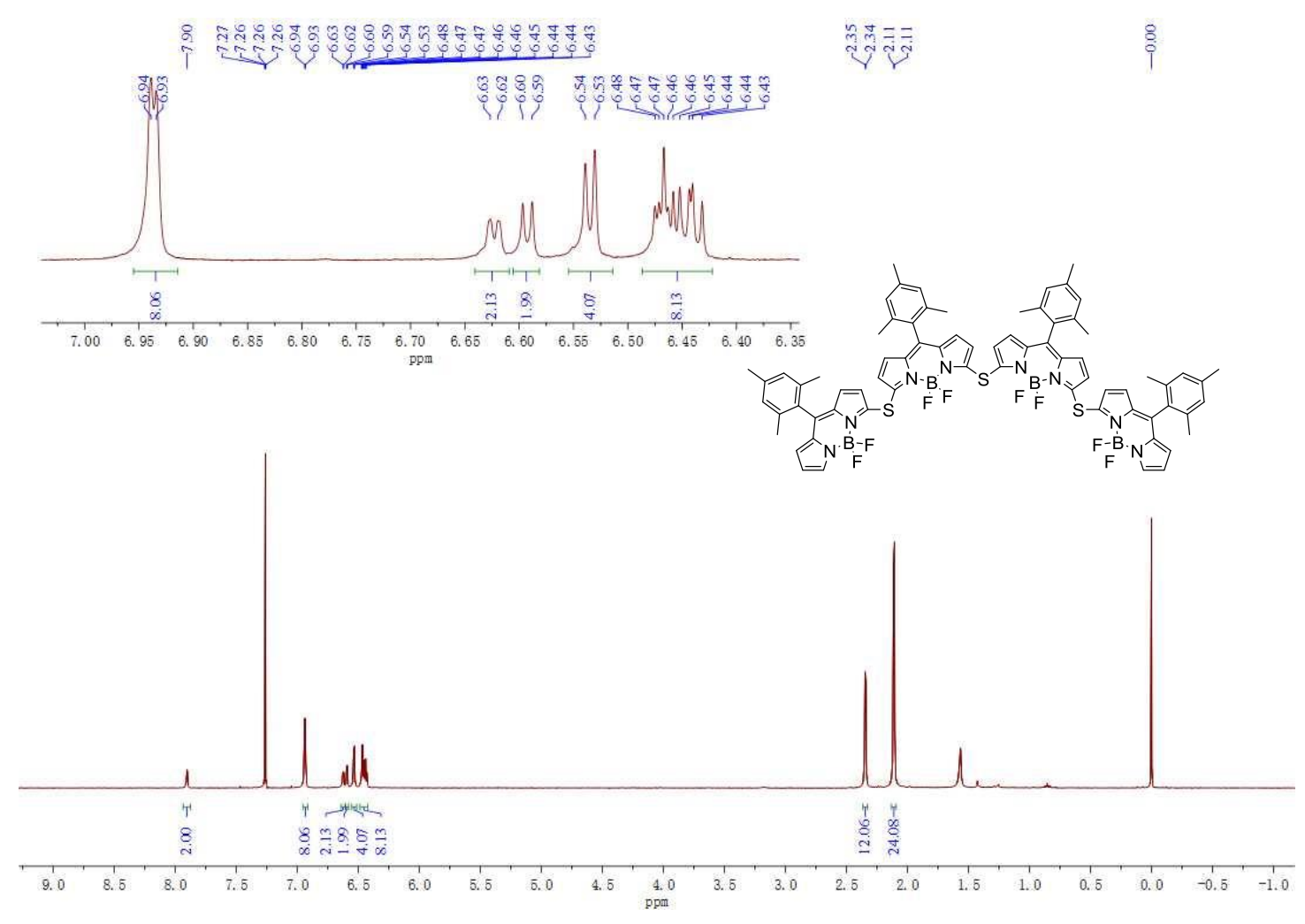

${ }^{1} \mathrm{H}$ NMR spectrum of $\mathbf{B 4}\left(\mathrm{CDCl}_{3}, 500 \mathrm{MHz}\right)$

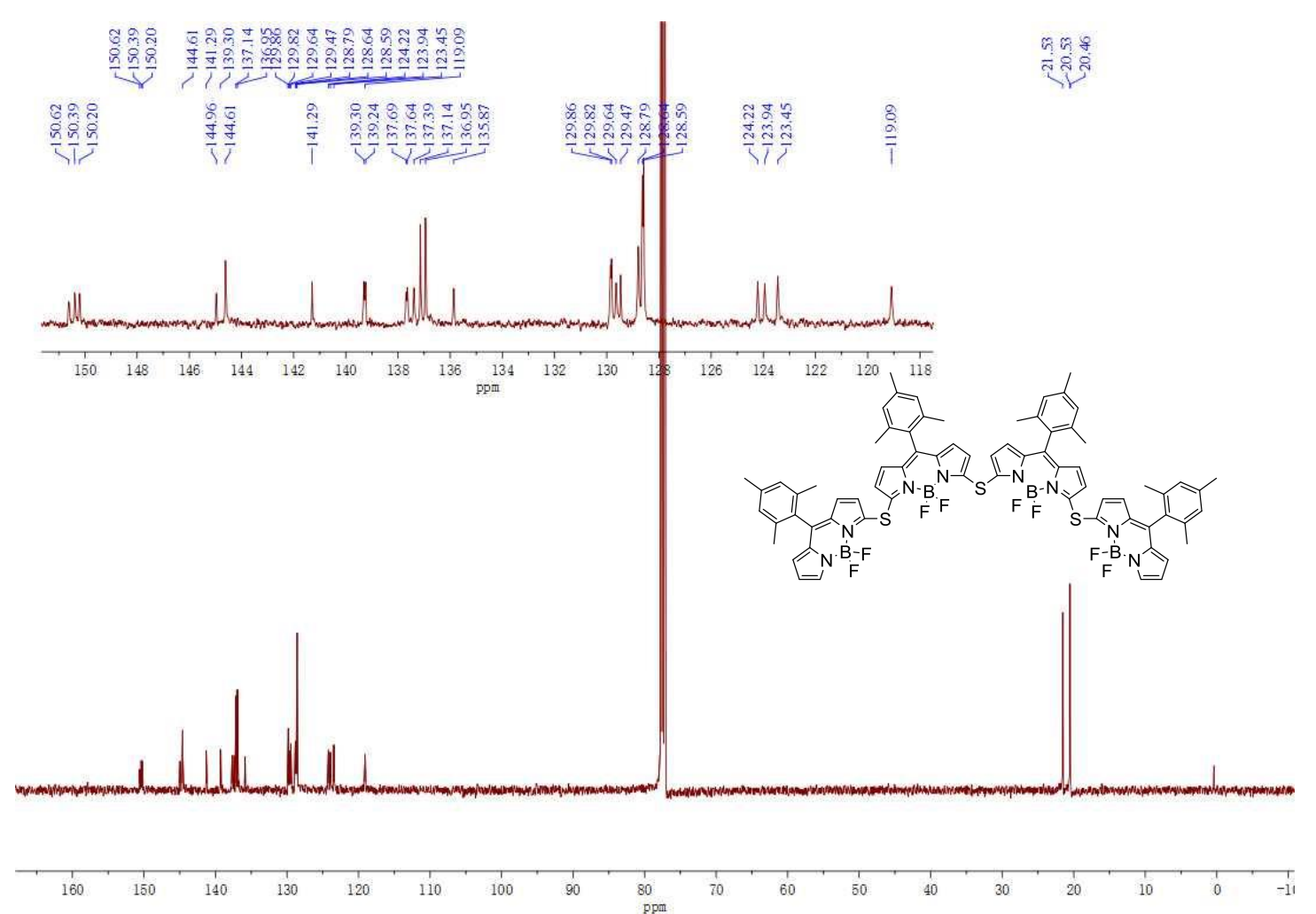

${ }^{13} \mathrm{C}$ NMR spectrum of $\mathbf{B} 4\left(\mathrm{CDCl}_{3}, 126 \mathrm{MHz}\right)$ 


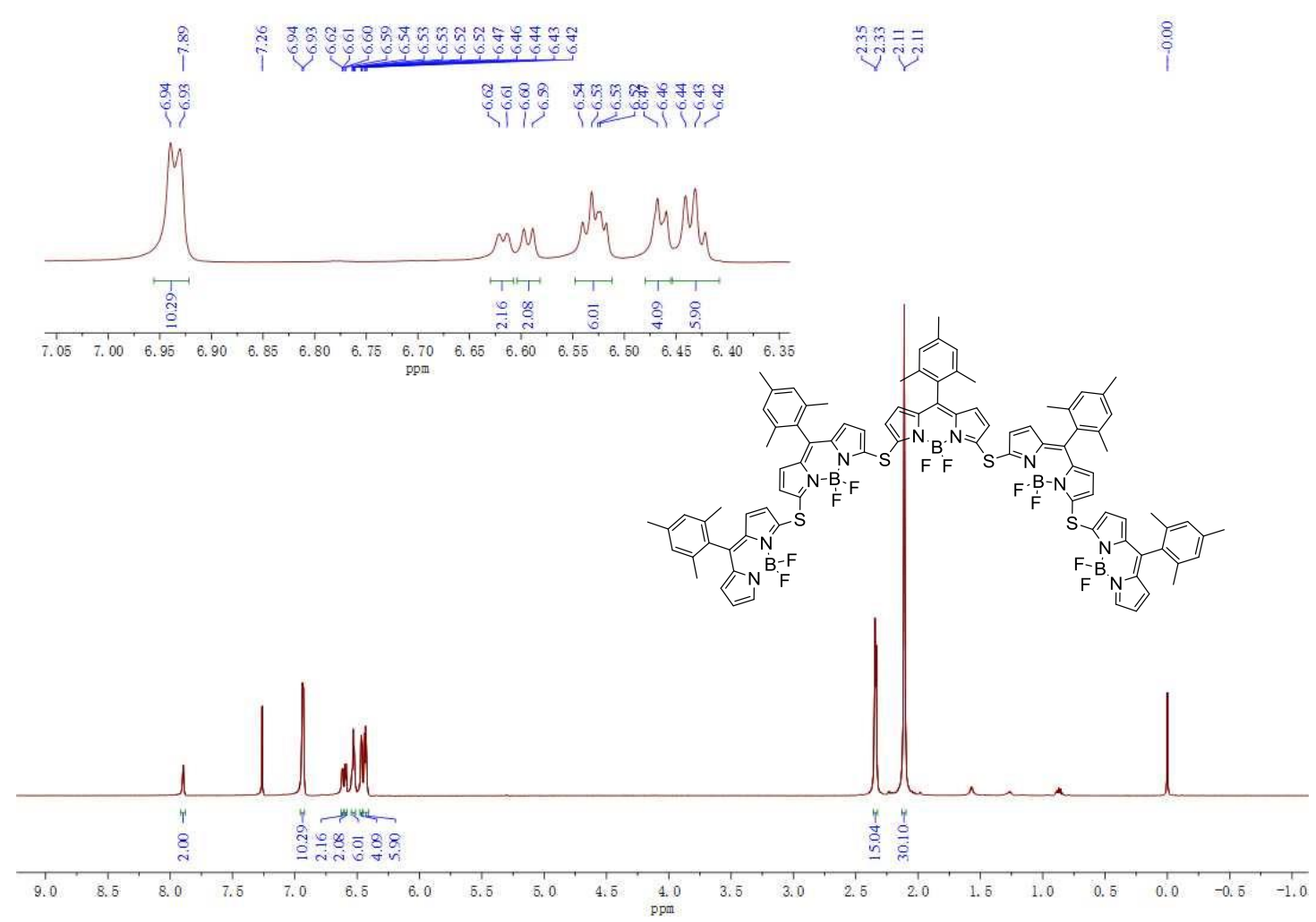

${ }^{1} \mathrm{H}$ NMR spectrum of $\mathbf{B 5}\left(\mathrm{CDCl}_{3}, 500 \mathrm{MHz}\right)$
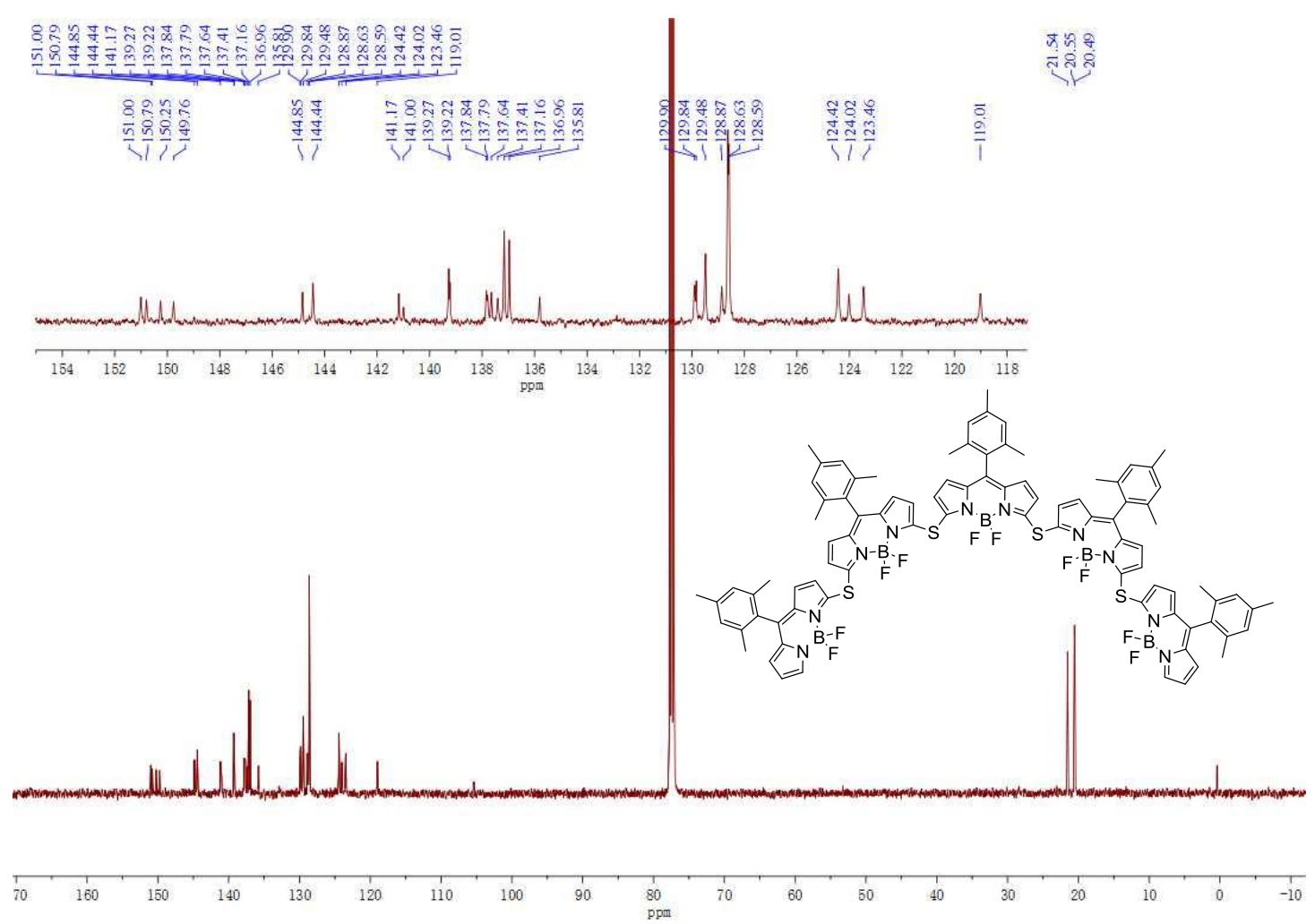

${ }^{13} \mathrm{C}$ NMR spectrum of $\mathbf{B 5}\left(\mathrm{CDCl}_{3}, 126 \mathrm{MHz}\right)$ 


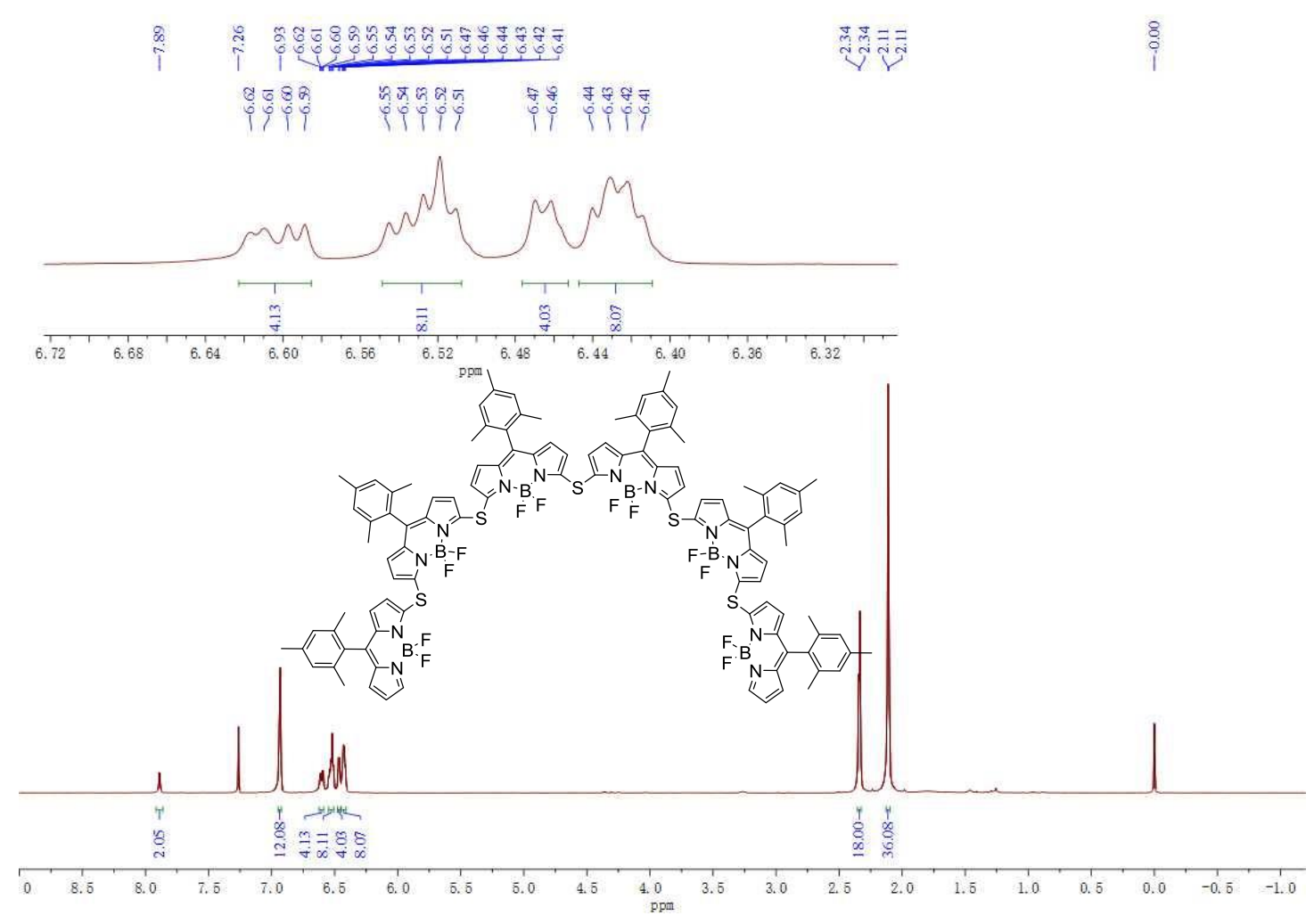

${ }^{1} \mathrm{H}$ NMR spectrum of $\mathbf{B 6}\left(\mathrm{CDCl}_{3}, 500 \mathrm{MHz}\right)$

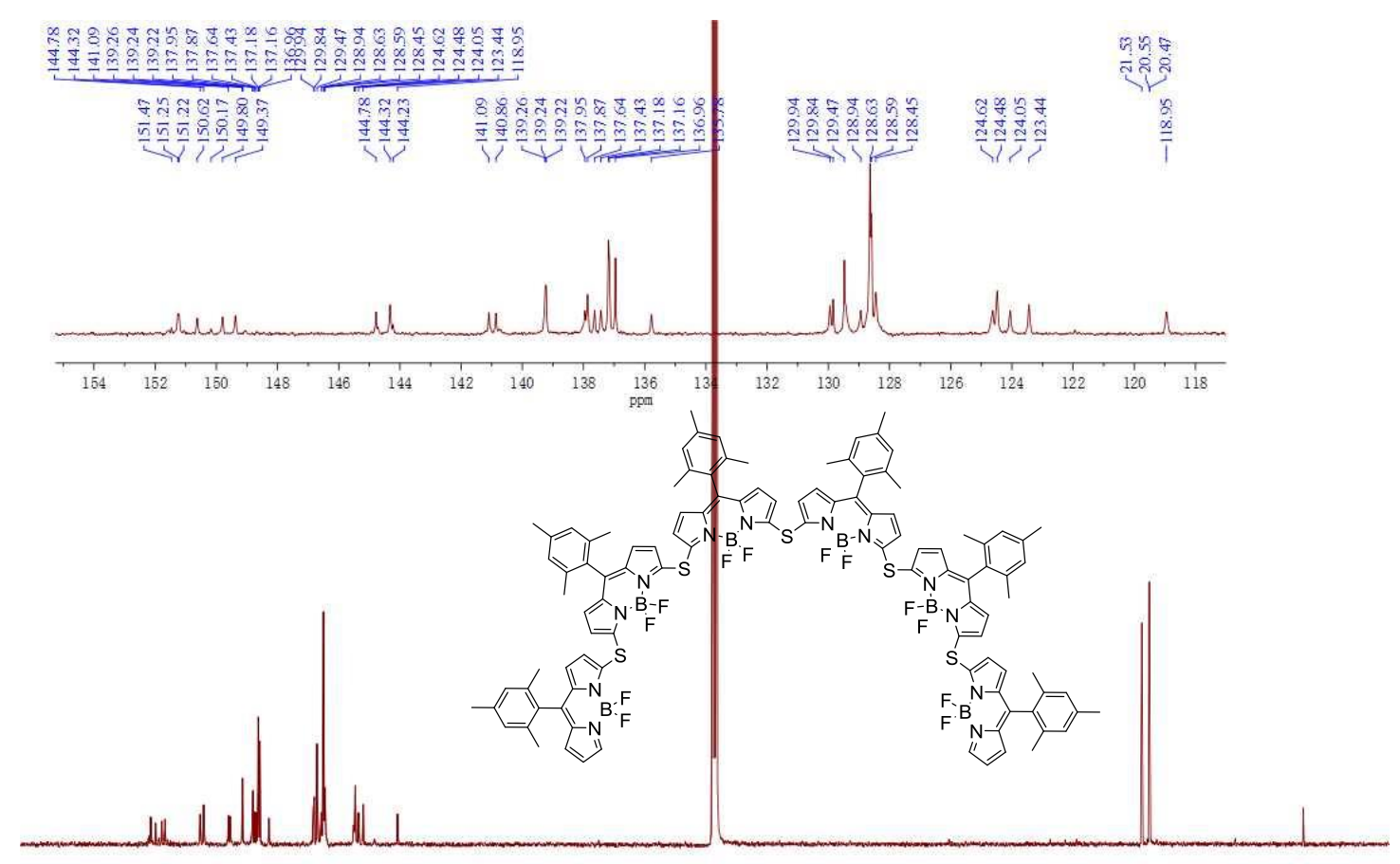

${ }^{13} \mathrm{C}$ NMR spectrum of $\mathbf{B 6}\left(\mathrm{CDCl}_{3}, 126 \mathrm{MHz}\right)$ 


\section{High resolution mass spectroscopes for all new compound}

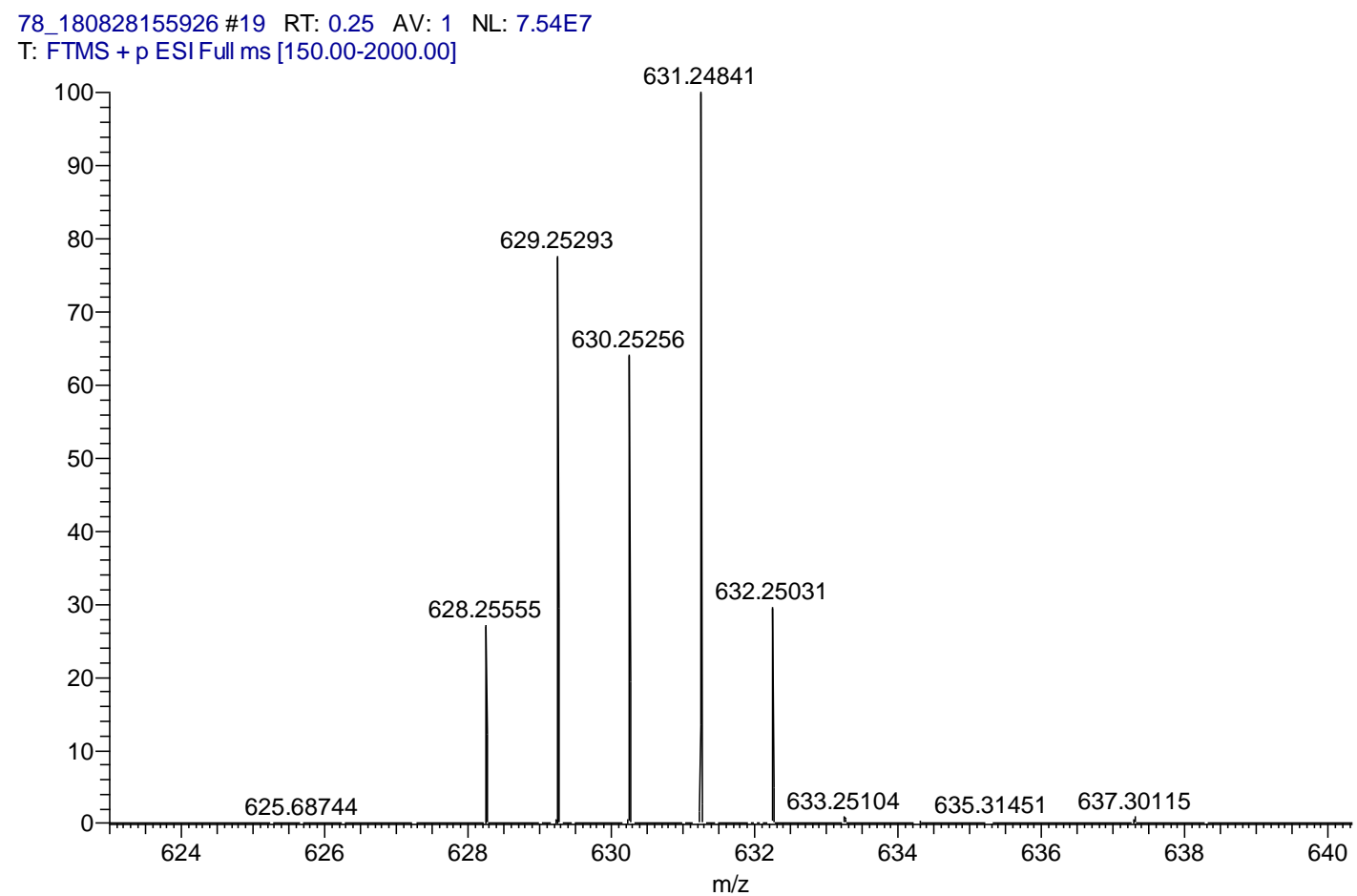

HRMS for B2

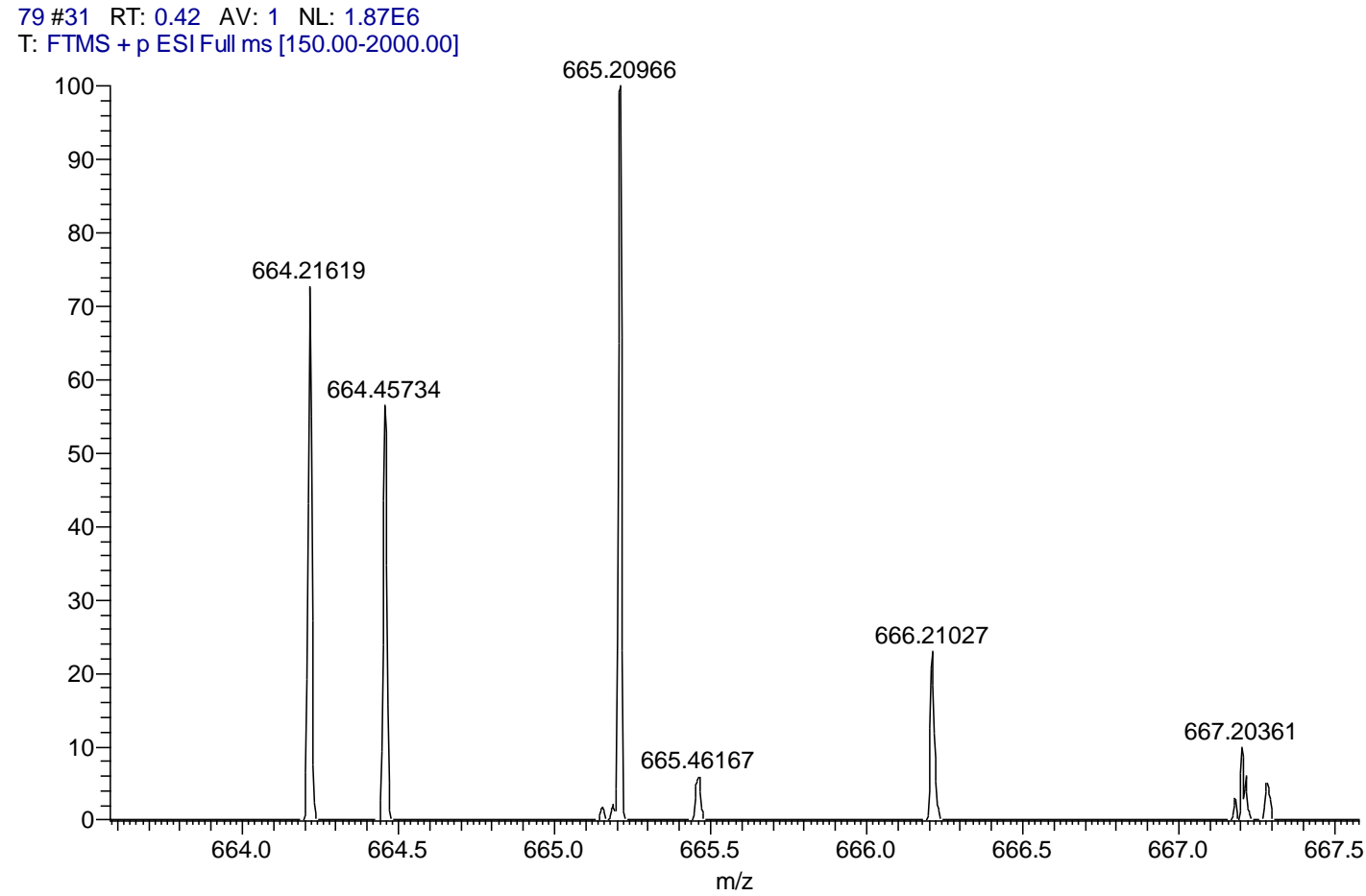

HRMS for B2-Cl 


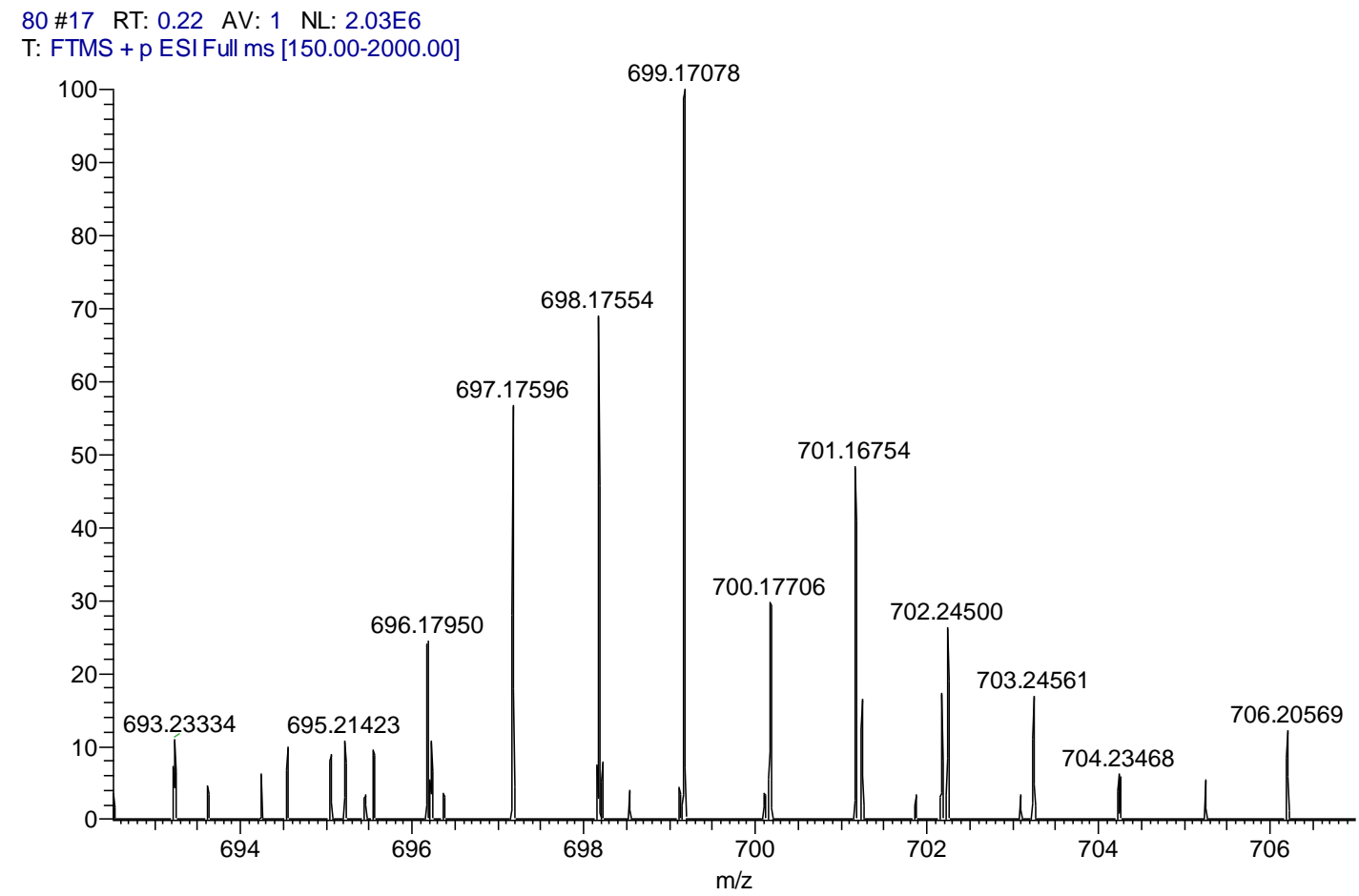

HRMS for B2-2Cl

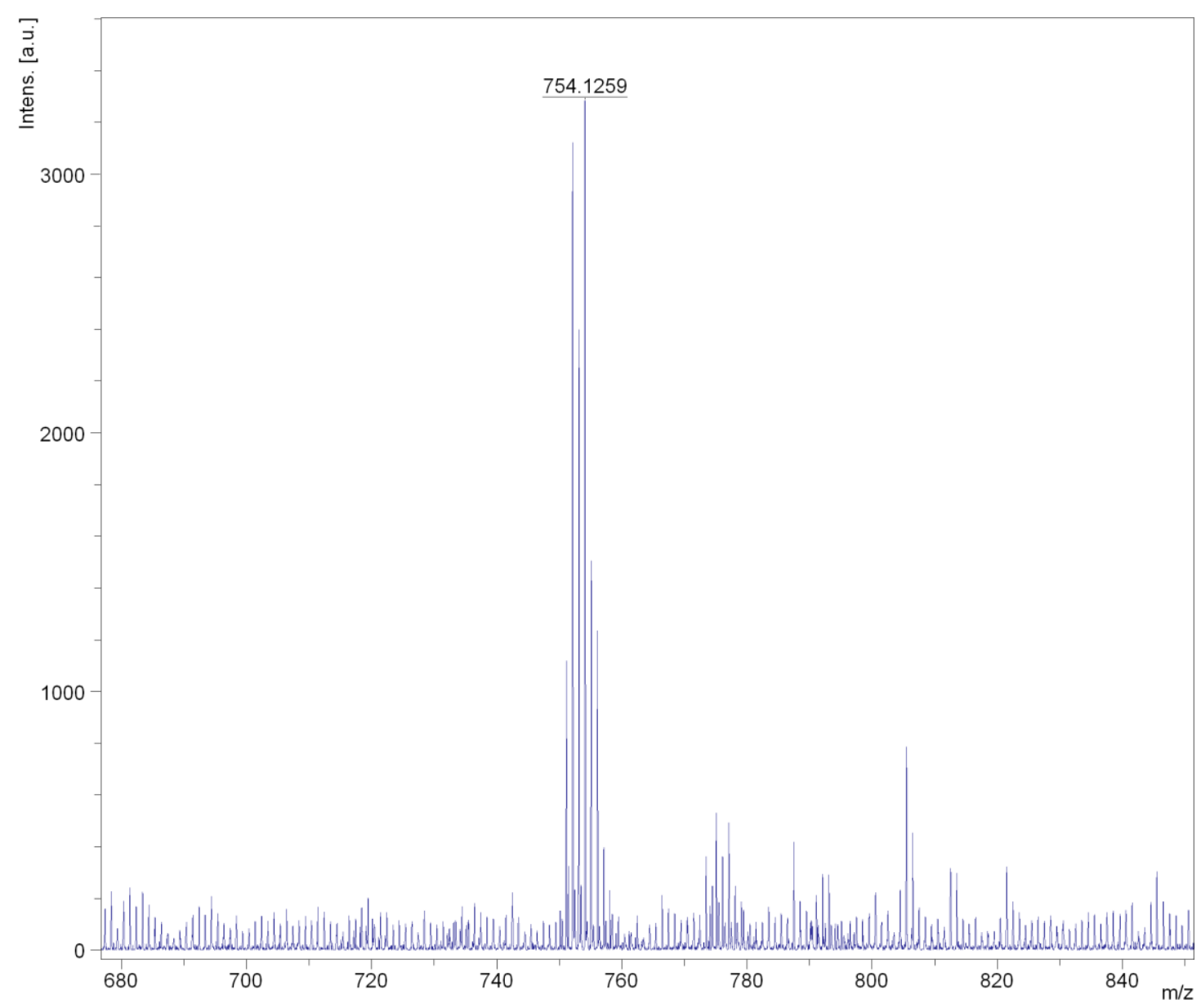

HRMS for B2-3Cl 


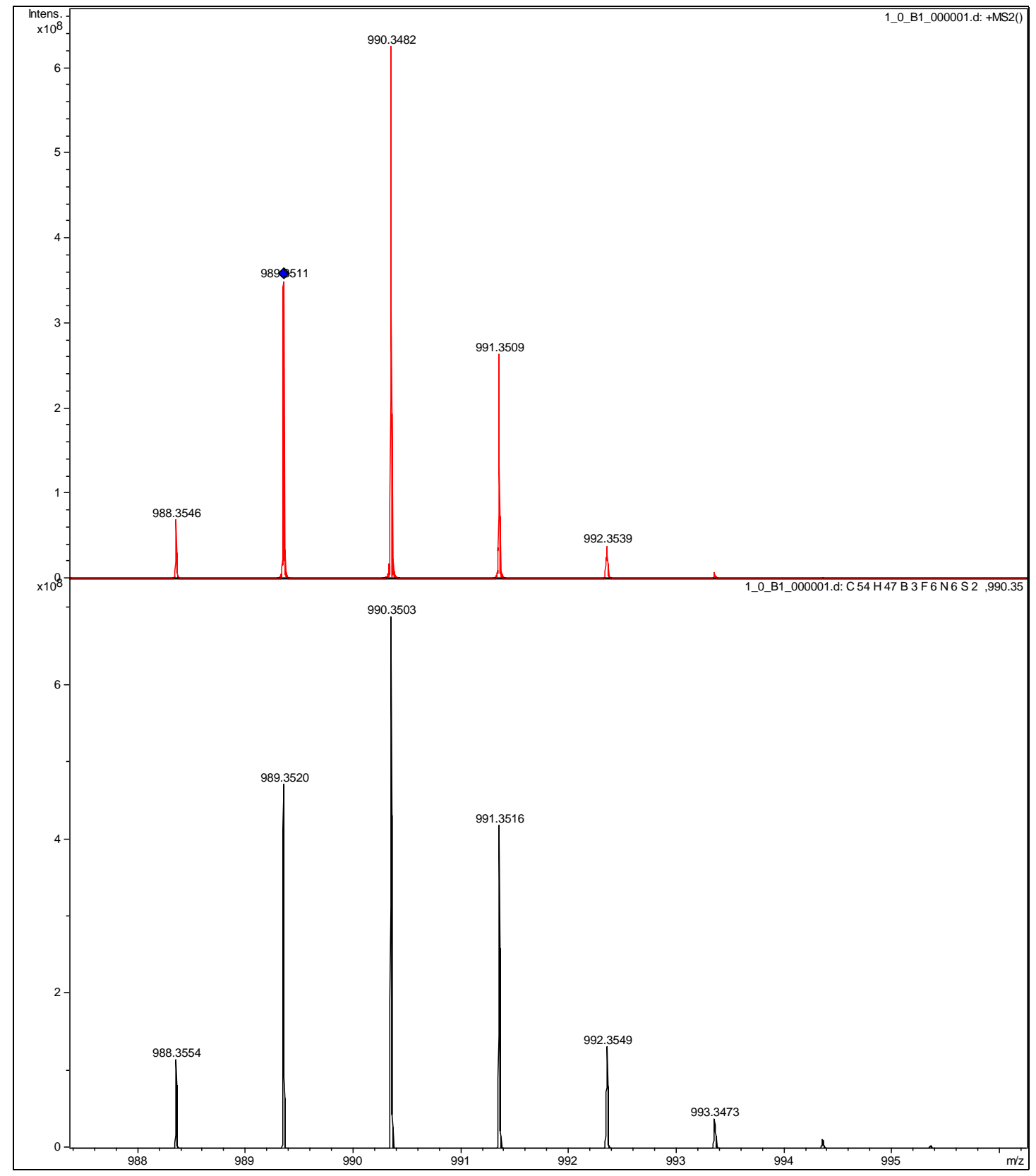

HRMS for $\mathbf{B} 3$ 


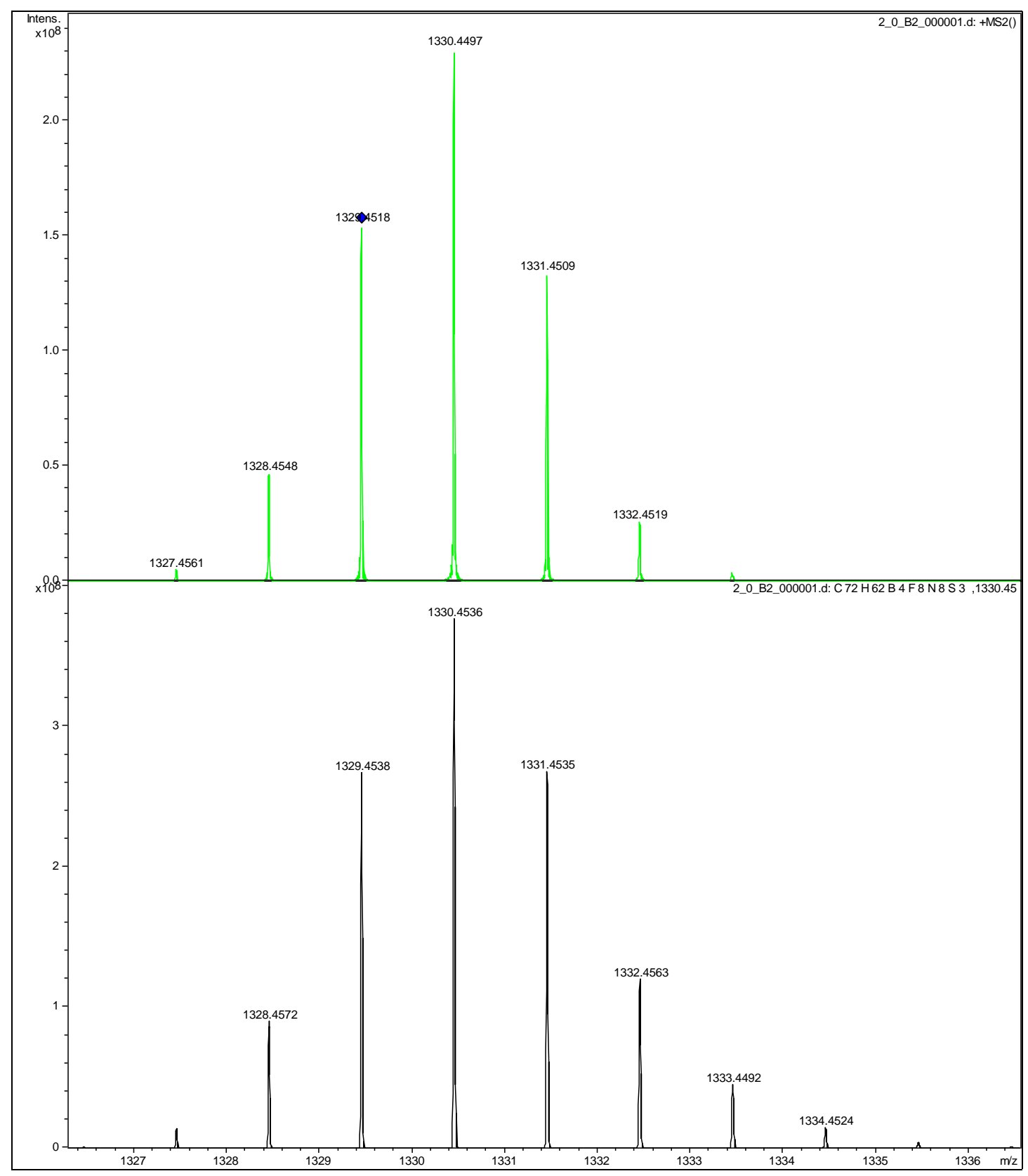

HRMS for B4 


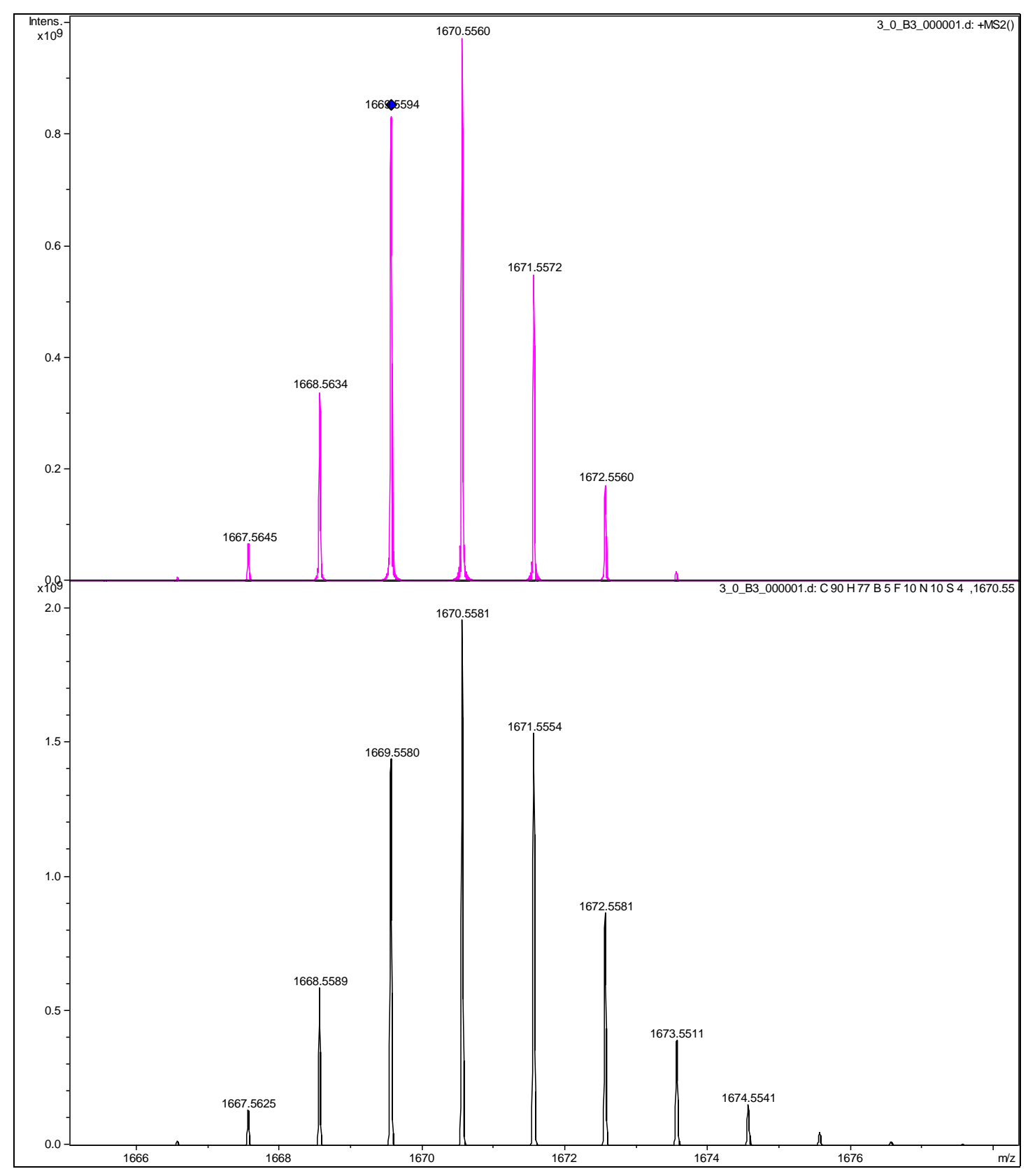

HRMS for $\mathbf{B 5}$ 


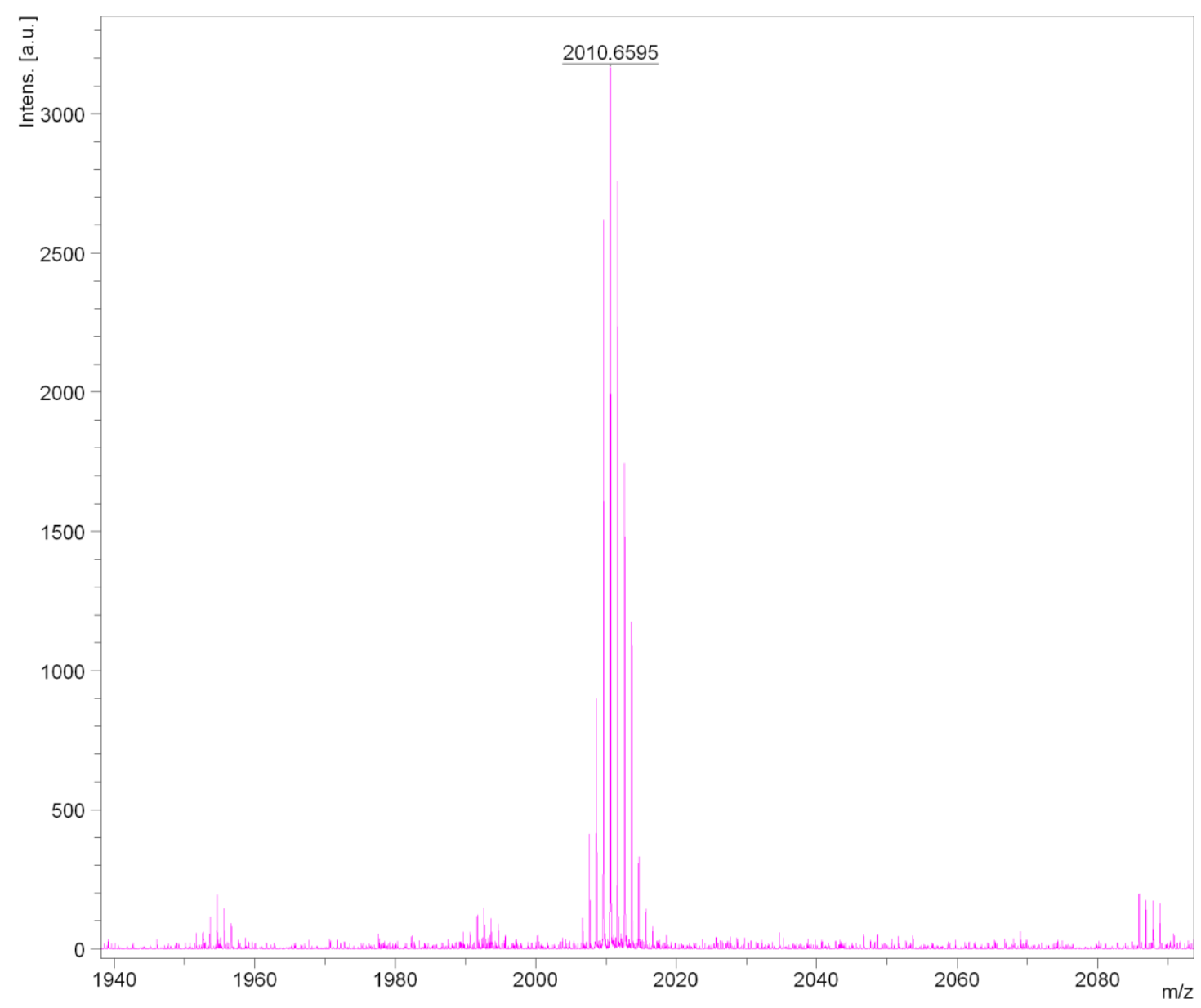

HRMS for $\mathbf{B 6}$ 


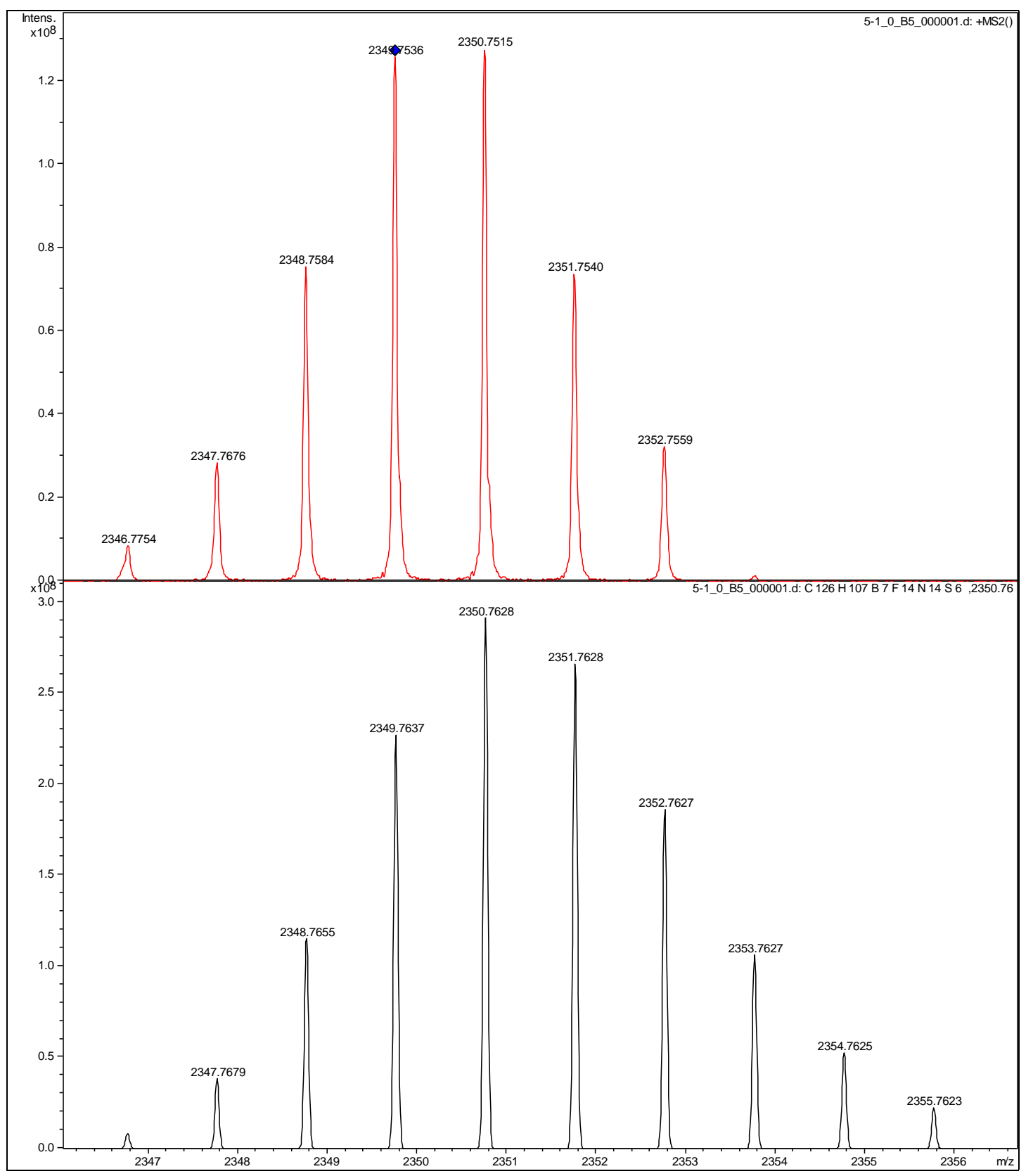

HRMS for B7

S57 


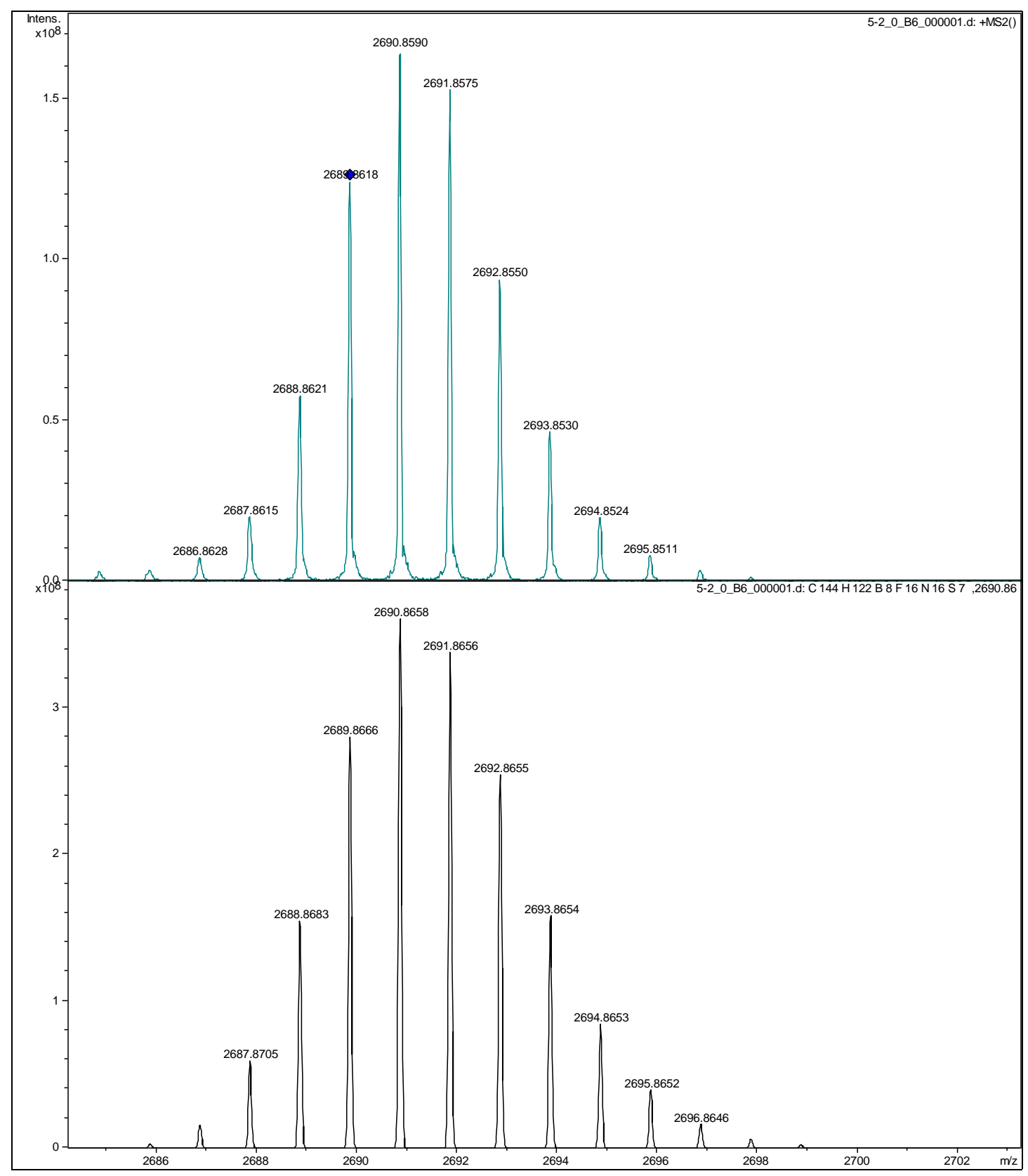

HRMS for $\mathbf{B 8}$ 


\section{Reference}

1) Isak, S.; Eyring, E. J. Phys. Chem. 1992, 96, 1738.

2) (a) Killoran, J.; Allen, L.; Gallagher, J. F.; Gallagher, W. M.; O'Shea. D. F. Chem. Commun. 2002, 1862. (b) McDonnell, S. O.; Hall, M. J.; Allen, L. T.; Byrne, A.; Gallagher, W. M.; O’Shea, D. F. J. Am. Chem. Soc. 2005, 127, 16360.

3) Software for the integration of CCD detector system Bruker analytical X-ray systems, Bruker axs, Madison, WI (after 2013).

4) APEX2 suite for crystallographic software, Bruker axs, Madison, WI.

5) Dolomanov, O.; BourhisL, J.; Gildea, R.; Howard, J.; Puschmann, H. Olex2: A complete structure solution, refinement and analysis program, J. Appl. Cryst, 2009, 42, 339.

6) Sheldrick, G.M. Crystal structure refinement with ShelXL, Acta Cryst, 2015, A71, 3.

7) Zhou, X.; Yu, C.; Feng, Z.; Yu, Y.; Wang, J.; Hao, E.; Wei, Y.; Mu, X.; Jiao, L. Org. Lett. 2015, 17,4632 .

8) a) Usui, Y. Chem. Lett. 1973, 2, 743. b) Li, W.; Li, L.; Xiao, H.; Qi, R.; Huang, Y.; Xie, Z.; Jing, X.; Zhang, H. RSC Adv. 2013, 3, 13417; c) Feng, Z.; Feng, Y.; Yu, C.; Dai, E.; Wei, Y.; Mu, X.; Jiao, L.; Hao, E. J. Org. Chem. 2016, 81, 6281; d) Batat, P.; Cantuel, M.; Jonusauskas, G.; Scarpantonio, L.; Palma, A.; O'Shea, D. F.; McClenaghan, N. D. J. Phys. Chem. A 2011, $115,14034$.

9) (a) Gaussian 09, Revision D.01, M. J. Frisch, G. W. Trucks, H. B. Schlegel, G. E. Scuseria, M. A. Robb, J. R. Cheeseman, G. Scalmani, V. Barone, B. Mennucci, G. A. Petersson, H. Nakatsuji, M. Caricato, X. Li, H. P. Hratchian, A. F. Izmaylov, J. Bloino, G. Zheng, J. L. Sonnenberg, M. Hada, M. Ehara, K. Toyota, R. Fukuda, J. Hasegawa, M. Ishida, T. Nakajima, Y. Honda, O. Kitao, H. Nakai, T. Vreven, J. A. Montgomery, Jr., J. E. Peralta, F. Ogliaro, M. Bearpark, J. J. Heyd, E. Brothers, K. N. Kudin, V. N. Staroverov, T. Keith, R. Kobayashi, J. Normand, K. Raghavachari, A. Rendell, J. C. Burant, S. S. Iyengar, J. Tomasi, M. Cossi, N. Rega, J. M. Millam, M. Klene, J. E. Knox, J. B. Cross, V. Bakken, C. Adamo, J. Jaramillo, R. Gomperts, R. E. Stratmann, O. Yazyev, A. J. Austin, R. Cammi, C. Pomelli, J. W. Ochterski, R. L. Martin, K. Morokuma, V. G. Zakrzewski, G. A. Voth, P. Salvador, J. J. Dannenberg, S. Dapprich, A. D. Daniels, O. Farkas, J. B. Foresman, J. V. Ortiz, J. Cioslowski, and D. J. Fox, Gaussian, Inc., Wallingford CT, 2013; (b) Rinkevicius, Z., Tunell, I., Sałek, P., Vahtras, O., Ågren, H. J. Chem. Phys. 2003, 119, 34-46; (c) Helgaker, T., Jørgensen, P., Olsen, J., Ruud, K., Andersen, T., Bak, KL., Bakken, V., Christiansen, O., Dahle, P., Dalskov, EK., Enevoldsen, T., Heiberg, H., Hettema, H., Jonsson, D., Kirpekar, S., Kobayashi, R., Koch, H., Mikkelsen, KV., Norman, P., Packer, MJ., Saue, T., Taylor, PR., Vahtras, O., Jensen, HJA., Ågren, H. Dalton, an Ab Initio Electronic Structure Program, 1.0. 1997; (d) Koseki, S., Schmidt, M., Gordon, M. J. Phys. Chem. 1990, 96, 10678. 